\title{
Early Black Poetry, Social Justice, and Black Children: Receptions of Child Activism in African American Literary History
}

\author{
Tabitha LaShay Joy Lowery \\ West Virginia University, talowery@mix.wvu.edu
}

Follow this and additional works at: https://researchrepository.wvu.edu/etd

Part of the Children's and Young Adult Literature Commons, and the Literature in English, North America, Ethnic and Cultural Minority Commons

\footnotetext{
Recommended Citation

Lowery, Tabitha LaShay Joy, "Early Black Poetry, Social Justice, and Black Children: Receptions of Child Activism in African American Literary History" (2020). Graduate Theses, Dissertations, and Problem Reports. 7787.

https://researchrepository.wvu.edu/etd/7787

This Dissertation is protected by copyright and/or related rights. It has been brought to you by the The Research Repository @ WVU with permission from the rights-holder(s). You are free to use this Dissertation in any way that is permitted by the copyright and related rights legislation that applies to your use. For other uses you must obtain permission from the rights-holder(s) directly, unless additional rights are indicated by a Creative Commons license in the record and/ or on the work itself. This Dissertation has been accepted for inclusion in WVU Graduate Theses, Dissertations, and Problem Reports collection by an authorized administrator of The Research Repository @ WVU. For more information, please contact researchrepository@mail.wvu.edu.
} 
Early Black Poetry, Social Justice, and Black Children: Receptions of Child Activism in African American Literary History

Tabitha LaShay Joy Lowery 
Early Black Poetry, Social Justice, and Black Children:

Receptions of Child Activism in African American Literary History

\section{Tabitha Lowery}

Dissertation submitted to the Eberly College of Arts and Sciences at West Virginia University in partial fulfilment of the requirements for the degree of

Doctor of Philosophy in

English

Timothy Sweet, PhD., Chair

Gwen Bergner, Ph.D.

Cari Carpenter, Ph.D.

John Ernest, Ph.D.

Department of English

Morgantown, West Virginia

2020

Keywords: Reception History, African American Literary History, Poetry, Uplift, Race, Gender, Canon Formation, Children's Literature, Childhood

Copyright 2020 Tabitha Lowery 


\begin{abstract}
Early Black Poetry, Social Justice, and Black Children:

Receptions of Child Activism in African American Literary History
\end{abstract}

Tabitha Lowery

In spite of the substantial amount of critical work that has been produced on the recovery of early African American literature in the last few decades, our representations of black authors are still limited. Current studies of early African American poets privilege the identification of African American literature with resistance to slavery. This identification has persisted and has made the field one-dimensional. My dissertation provides reception histories of four early black poets - Phillis Wheatley, George Moses Horton, Frances Harper, and Paul Laurence Dunbar-to argue for and present an expansive understanding of African American literature. A thorough examination of these authors' circulation histories reveal that editors engaged in children's literature, a topic that is often overlooked in African American literary history. I argue that editors and sometimes poets recirculated black poetry in the interest of training children for social justice activism. This topic requires scholars to reconsider the complex cultural influences that shape their representations of early black authors; it will also allow for the inclusion of early black authors into white spaces. Forgetting these histories further deepens the gaps between recovered and unrecovered works.

Scholars often represent Wheatley as a poet concerned with appropriating western language or subtly resisting western hegemony. Chapter one argues for the importance of Wheatley's neglected poems by examining an unrecognized circulation history. My research reveals how various kinds of readers often repurposed Wheatley's poems to provide varying forms of moral uplift that subjugated black children to dominant political forces. By using Arthur Donaldson's Juvenile Magazine (1811, 1813), Freedom's Journal (1827-1829), and even The Upward Path (1920), just to name a few, I uncover the ways editors used Wheatley's moral poetry to teach varying forms of uplift to black children.

My second chapter will redirect attention back to Horton as a nature poet for black children to recharacterize Horton's importance in shaping black identities. Horton's obscurity attests to the ways scholars have characterized his poetry as simply derivative of white models of poetry. I examine publications such as Eliza Follen's juvenile magazine, The Child's Friend (1843-1858), and Lydia Marie Child's The Freedmen's Book (1865) to argue that Horton's poetry was used to teach black and white children rhyme and romantic ideations of nature to reshape their relationship to the turbulent American landscape of nineteenth-century America.

Chapter three reorients Harper's poems in the context of children's literature to reimagine Harper not only as an advocate for black and white adults, but for children as well. My research refocuses commonly anthologized poems to consider how they speak to black children in the mid-nineteenth and late-twentieth centuries. The Anglo-African Magazine (1859-1860), William Wells Brown's The Black Man (1863), and The Freedmen's Book (1865), among others attest to the ways Harper's poems were reimagined for child audiences.

Chapter four relocates Dunbar in contexts of children's literature that sought to make Dunbar the ideal early black writer for black children. Relocating Dunbar as a children's poet rouses more scholarly attention toward Dunbar's Christmas poems and poems that went beyond 
racial themes. My analysis of Readings from Negro Authors (1931) and Christmas Gif'(1965) enables an unique perspective on Dunbar's representation.

My conclusion surveys the patterns that emerge in the representations of Wheatley, Horton, Harper, and Dunbar in several American literature anthologies and newspapers throughout four different periods. The collections, Over the River and Through the Wood (2014) and Who Writes for Black Children (2017) have garnered attention for topics of early black children's poets within African American literature, though more work remains to be done in ciphering through the messiness of nineteenth-century periodical culture. 


\section{Acknowledgments}

Two institutions provided funding over the course of my graduate career and for this project, and I am appreciative of their efforts. The Office of Graduate Education and Life at West Virginia University provided me with a W.E.B. Du Bois Fellowship for the beginning stages of my PhD program. The Department of English at West Virginia University provided financial support throughout my journey. In addition, The Provost Office at Middle Tennessee State University provided me with a Diversity Dissertation Fellowship that enabled me to complete the last year of my work. I would particularly like to thank Katherine Karraker, Constinia Charbonnette, Brian Ballentine, Cheryl Torsney, Peter Cunningham, Steve Severn, Darlene Fultz, the WVU, and MTSU English Departments for all of their help throughout my years at WVU and MTSU.

I also wish to acknowledge the many different faculty who helped me think through problems and ideas. I thank my chair, Tim Sweet for his patience and tireless guidance. Gwen Bergner, thank you for your attention to detail and for bringing to my awareness the greatness of black feminist thought. Cari Carpenter, thank you for your encouragement and feedback, which improved my critical thinking. John Ernest, thank you for inspiring me with your work and words. Also, I thank my many mentors and supporters who had a hand in my overall successTom Sura, Kate Pantiledes, Constinia Charbonnette, Ryan Claycomb, Cheryl Torsney, Maria Bachman, Eric Detweiler, Erica Cirillo-McCarthy, Mike Borshuk, Kanika Batra, Shannin Schroeder, Linda Tucker, Lynne Belcher, Mariah Crilley, Alex and Rose Moulton.

Finally, to my family and friends, thank you from the bottom of my heart. Without you, this journey would have been too much to bear alone. Special thanks to my mother and father, Eileen and Lonnie Lowery, whose words and love always inspired me to persist. To my siblings 
Brittany Williams, Kalieta Primm, and Brian Lowery, thank you for your continued support. Those phone calls helped me get through the toughest days. To my grandparents, whose resilience inspired me to persevere, thank you. To my many aunts, uncles, cousins, and family friends, I felt and appreciated your support. To my boyfriend, Otis Tramble, thank you for your love and for always being there for me throughout my entire journey in graduate school. And finally, to my closest friends - Tyler Davis, Aaron Goodson, and Kelli Wilhelm - thank you for pushing me to keep going no matter what. 
Table of Contents

Introduction

Chapter 1

12

Chapter 2

55

Chapter 3

90

Chapter 4

128

Conclusion

164

Works Cited

173 


\section{Introduction}

Articulations of African American childhood play a large role in the development of early black poets' philosophies and receptions and merit greater discussion than they currently receive within African American literature. Particularly, legacies of nineteenth century ideations of black child activism and humanity continue to exist at the center of continuing social justice issues such as police brutality and racial bias. Even as early as 1811, editors incorporated poems addressing the humanity and uplift of black children to challenge racial injustices posed against African American children. In the latter half of the nineteenth century, black and white editors continued to repurpose black poetry with the aim of instilling black children with notions of uplift, pride, and activism. After the early twentieth century, discussions of black children's representations continued though not as much during the Harlem Renaissance, which focused less on child readers and more on adults (with the exception of Langston Hughes and Countee Cullen). Within discussions of black poets' receptions and in the field of African American literature, however, black childhood activism has been largely ignored. This concept does not receive as much attention as adult resistance in poetry. Consequently, its philosophies and literature remain an ignored part of African American literary history.

The slave narrative was the primary genre for theorists such as Henry Louis Gates and Houston Baker who succeeded in bringing African American literature into the canon. This identification of African American literature with resistance to slavery has persisted and has made the field one-dimensional. The field has advanced in such a way that it can allow other stories. Frances Smith Foster set an example with stories of love and marriage, Eric Gardner conveys stories of the print networks of black print culture, and Derrick Spires describes the ways African Americans theorized citizenship in the antebellum era. Another important story is 
about African American childhood and social justice activism. The following examines historical constructions of nineteenth-century white and black childhood and the children's literature market. The last section offers a method for analyzing the reception histories of black poets in relation to these histories. I argue that the circulation histories of the poems of Phillis Wheatley, George Moses Horton, Frances Harper, and Paul Laurence Dunbar reveal the ways editors and authors used black poetry to educate children. More particularly, editors and authors promoted social justice activism in children's circles to help them reclaim their humanity and positionality in the U.S. My work suggests that the recovery of black poetry in children's publications provides nuanced and broader representations of early black authors in college and high school classrooms.

\section{Historical Constructions of White and Black Childhood}

Constructions of white and black childhood limited black children's liberation, but they also allowed spaces for mobility. The pickaninny construction of black childhood did not gain much traction until the 1820 s and 30 s. Before this depiction, the most dangerous attempts to deny black children their childhood and education had not yet been formed (Weikle-Mills 24). Gradual emancipation ensured that most black children could read in order to transform themselves into subjects in American society. As a result, abolitionists and black editors of the early nineteenth century repurposed works from Phillis Wheatley to help black children form imaginative spaces for their participation in society. Early abolitionists and editors produced radical agendas by creating children's literature that spoke to black children specifically. Smith and Duane explain, "To imagine the black child as literate, upwardly mobile, and capable of inhabiting the same stories that were told to the future white citizens of the United States was to 
attack the radical hierarchies at the root" (xi). Laced with paternalism, however, early white uplift agendas limited black child liberalism and activism. Additionally, after white society implemented stringent laws that handicapped black educational efforts, the work to train black children to recognize their humanity and activism remained daunting, but not impossible.

Editors found creative ways to teach children activism and societal participation later in the nineteenth century. Newspapers circulated Horton's lyrical poetry to teach black children about nature, morality and citizenship, and friendship. Women-authored juvenile literature repurposed Horton to teach friendship and activism mainly to white child audiences, though the editors encourage white children to unite with black children. In their teachings, white women abolitionists worked to humanize black children by publishing Horton's poems and placing tales of friendship between blacks and whites into their magazines.

In later decades, editors began repurposing early back poets to articulate middle-class values of morality and uplift. Some black poets signified middle-class values and used them to galvanize black children toward activism. Black educated women and men responded to racist portrayals with racial uplift ideology. Kevin Gaines explains that the ideology signified aspiration, advancement, and struggle, however, black elites used it to create a racialized elite identity (xiv). Black improvement, as most black elites claimed, worked through class stratification - in other words, the improvement of black individuals depended upon their acceptance and performance of bourgeois values. Bourgeois values inspired many to consider education as the key to liberation. Black elites hoped that in response, white individuals recognized the humanity of middle-class African Americans. Poets such as Frances Harper accepted conservative ideals of middle-class racial uplift and often taught them to lower classes of African Americans. However, her poetry does not fully accept the bourgeoisie standards of 
Victorian ideals. Nevertheless, her poetry and speeches clearly targeted black children as the future of the race's progress. She promoted black child activism and used her poetry to introduce social justice topics to children. Editors continued this strand of her legacy into the twentieth century.

The New Negro period started the search for a new literature that better represented black experiences. From this point on in different ideations, black American literature was chosen to fulfill those goals. As the twentieth century drew to a close, the multiculturalist movement influenced future representations of early black poets. Poets such as Dunbar became memorialized as a poet who represented African American heritage. Most early poets and their associations to black children's activism became ignored by this time as other histories were emphasized. Black American children's literature became more focused on teaching children about their heritage, experiences, and beauty. Not many collections focused on extending participation in activism to black children.

\section{The Children's Literature Market}

The market for children's literature developed slowly before the Civil War and expanded dramatically after the war. Scholars Karen L. Kilcup and Angela Sorby explain that most children's poetry collections in the U.S. catered to small children learning to read (3). Children with advanced reading skills read family-oriented volumes from schoolroom poets such as Longfellow, Whittier, and Bryant (Kilcup and Sorby 4). The lines between adult and child literature were blurred in the early parts of the nineteenth century and in times, into the latter half as well. As educational opportunities expanded, schoolrooms taught poetry, which became important for the transmission of American ideals. Sorby points out that generations of students learned canonical poetry that affirmed their statuses as educated Americans (4). After the Civil 
War, the market for children's literature and the middle class expanded. The literature market began specializing in children's literature and distributed didactic materials that middle-class families accepted as signifiers of social status. The schoolroom poets quickly became associated with upper-class poetry and became a part of a nostalgic "childhood" of which white students accessed.

The children's literature market affected black children differently. Scholars Katharine Smith and Anna Mae Duane offer studies of eighteenth and nineteenth-century black children's literary culture in their collection Who Writes for Black Children? (2017). The collection features a corrective history that makes visible black child readers in African American literature. Before the establishment of laws prohibiting black child readers, early black poets such as Jupiter Hammon encouraged black readers to read religious texts as they provided children autonomy. Courtney Weikle-Mills explains:

the first published writing by African Americans bears a special relationship to childhood, because childhood created a space where black writers could appropriate beliefs about children's capacity for growth and change to facilitate early publication and emancipation efforts. (22)

I build off Weikle-Mills' argument in the first chapter, which includes Phillis Wheatley's reception. She argues that Jupiter Hammon's writing bears a relationship to childhood because “childhood created a space where black writers could appropriate beliefs about children's capacity for growth and change to facilitate early publication and emancipation efforts" (WeikleMills 22). While she relies on Hammon's texts that directly addressed children, my project moves beyond authors to focus also on the editors who circulated their texts. Doing so extends analysis to other black writers who played a role in early black children's education less directly, 
such as Wheatley. For instance, early nineteenth-century Quaker abolitionist Arthur Donaldson created a school for black children and circulated texts for and sometimes by African Americans. He featured four of Wheatley's poems, which have highly elevated language. Though WeikleMills' stance relies on how black authors directly addressed children and wrote in connection to childhood, my argument extends this analysis to include forgotten editors who also played a role in Wheatley's formation as a children's author. Studying how each editor repurposed her works also reveals early editors' efforts to allow black women writers the opportunity to appear in print. Extending the field to include less-familiar writings supposedly from black women such as Mary Perth places black women as predecessors of children's magazines and reorients the ways that scholars talk about the progenitors of nineteenth-century children's magazines.

\section{Circulation Histories}

My argument does not suggest that circulation histories offer intrinsic information about the representation of black authors. It in fact, argues the opposite - that circulation histories offer non-essentialized views into an author's oeuvre. As a way to understand black writing, critics in past and contemporary periods create theoretical models that reveal ethnic difference in black authors' writings. The tradition to find signs of authenticity from a black text narrows inclusion to texts that fit this mold of "blackness." When articulating a tradition of black writing, some scholars rely on themes of signifying, subversion, and authenticity as tools for choosing black writing. The circulation of a text, however, relies upon a system of recognition and understanding that is already in place to guide circulation. That is, the tastes and values of a particular historical moment dictate the ways the text is transmitted and disseminated to the public. As Michal C. Cohen states: 
Media, format, and genre create the 'system of relationships' that enables poems to circulate, and this system meets up with the local expectations of readers, whose reception of individual texts is guided by the system, but not completely (Cohen, Cultures of Poetry 3).

Therefore, understanding black poems in the ways that they were received offers a broader context for representing black authors. Textual elements such as format, media, and content, form expectations of readers, and readers derive meaning from these textual elements.

Along with reading poems in relation to materials in a given ephemeral text in the nineteenth century, Michael C. Cohen suggests that reading poems turns attention to the nontextual ways in which individuals used poems for meaning making. For instance, poems became tokens in scrapbook exchanges, they gained significance when printed beside other news items, or they captured the sentiments of a movement and transplanted ideologies and voices from one region to another. According to Cohen, poems in the nineteenth century often "facilitated actions such as reading, writing, reciting, copying, inscribing, exchanging, or circulating" (Cohen, Social Lives 7). Poems were written in newspapers, scrapbooks, and novels and were either copied or used in classrooms, especially in the mid-to-late nineteenth century (Cohen, Social Lives 7). Additionally, people valued poems as cultural capital for children in classrooms, where children recited popular poets such as John Greenleaf Whittier. Angela Sorby relates that poems were "sites to negotiate and resolve political social and cultural conflicts of the postbellum United States" (198). Also, “encounters with poems structured the experiences of much larger forms of being." Poetic genres in the nineteenth century helped to reform American culture when institutions such as science, politics, and the law lacked the capabilities of doing so (200). Anti-slavery poems especially those of Whittier in the 1830 s and 1840 s, were used to 
mobilize action against slavery, even if the modes for producing these voices often privileged white men. With the invention of the steam press, communication spread more rapidly within the United States as well as across the Atlantic. Cohen contends that the "blank, abstract conventions of antislavery poems promoted their circulatory power and intensified their messages about freedoms of speech, thought, and association, as well as freedom from chattel servitude" (Cohen, Social Lives 64).

Reception histories deserve more attention in the African American literary tradition for many reasons. This methodology presents lost histories that make more complex our understandings of central and obscure figures in the canon. They also complicate the ways we think about genre, authorship, and the parameters of African American literature. Reception histories help scholars excavate periodicals for lost African American writers. Eric Gardner, for example amassed valuable texts from the long-running periodical, the Christian Recorder and challenged our conceptions of the ways African Americans inserted themselves into American print culture. In addition, he uses subscriptions to trace the ways black readers participated in the formation of a collective community. Reception histories encourage scholars to consider the entanglement of race and its material forces in the conceptions of the black press, thereby encouraging future studies into the complexity of race production in early America.

\section{Chapter Overview}

My research focuses on the moments in history that offer glimpses of the values and tastes that propelled black authors into the literary world. I analyze newspapers, edited collections, and schoolroom texts as early as the nineteenth century to the twenty first century. I find that where laws hindered black youth and adults' abilities to learn to write, children's magazines often touted the remedy. In the nineteenth century, Quakers, abolitionists, and early 
black editors of newspapers and book collections sought to enhance the educational experiences and lives of enslaved and freed black youth and adults by circulating the works of Wheatley, Horton, Harper, and Dunbar. Additionally, black editors engaged their audiences with ideas of nature and freedom to further suggest the many facets of black identity in the nineteenth through twenty first centuries.

Chapter one analyzes the reception of Wheatley's poems from the early nineteenth to twenty-first centuries. I focus on various white and black-authored newspapers, magazines, and anthologies and I argue that Wheatley should be represented as a children's author due to the ways editors repurposed her poetry for black child readers. Drawing from Wheatley's Poems (1773), the first editor of this study, Arthur Donaldson, used his Juvenile Magazine $(1811,1813)$ to promote responsible black child subjects in American society. Weikle-Mills explains that "childhood provided a site for imagining and attempting to actualize liberty" (23). I argue that many editors found the opportunity to practice local citizenship with black children to prepare them as responsible agents in white society. Other nineteenth-century editors promoted similar strands from Wheatley's oeuvre. Today, people remember Wheatley as the foundational poet in the African-American literature canon. Unlike earlier black poets such as Jupiter Hammon, Wheatley's fame earned her a special seat in the canon, though people neglect much of the aforementioned history.

Chapter two explores Horton's reception from his first collection to the present. Horton's reception reveals not only his desires as an orator, but the desires of editors to repurpose his poems to teach black and white children morality and activism. More particularly, white editors such as Eliza Follen recirculated Horton's political poems to help white child readers of her magazine, The Child's Friend (1843-1858) understand empathy toward less fortunate black 
children. This was a Boston children's magazine that was mainly instructive and religious in content. However, a shift in focus occurred in Child's 1865 book when she published "Praise of Creation" and "Spring," which was intended for black school children. Horton soon fell into obscurity after the Civil War due to his subject matter and the turn away from moralistic poems for children in the twenty first century. Though a local poet, Horton's reception shows the continuation of editors' desires to create spaces for children to become participants in social justice.

My third chapter follows the reception of Harper's poems. In 1860, The Anglo-African Magazine (1859-1860), an early African American newspaper dedicated to African American literary production and political debate, circulated Harper's "Truth," a poem largely centering on a pastoral scene. On the surface, "Truth" appears simple and embodies a child-like demeanor and tone. However, Thomas Hamilton, the editor of the newspaper, included it to speak more on the relationship between blacks' struggles in the western world and in the natural world. Hamilton's magazine was meant for children as well, and this poem attests to this fact. Similar to Wheatley's and Horton's circulation history, abolitionists circulated Harper's poems for moral instruction for black children. Harper advocated for black children in her speeches and poetry and challenged their historical representations. As racial depictions of the pickaninny surfaced, Harper advocated for black children's participation in social justice as a way to reconstruct their humanity in white society. Her poetics helped shape black identities and challenged white constructions of childhood. William Wells Brown's The Black Man (1863) included Harper's “The Slave Mother," and "Advice to the Girls." Unlike Wheatley and Horton, Harper's poems show a stronger relation to girls and women, indicating that Brown also wanted to reach out to women in his anthology meant to show the intellectual capabilities of black writers. 
My final chapter focuses on the relationship between Dunbar's poems and how editors used them as activism for black children. Black newspapers and editors used Dunbar's Standard English and dialect poems to fashion middle-class markers of status for racial uplift. After the Civil Rights movements Dunbar's reputation was solidified as he represented the harbinger of black heritage. Dunbar's poems, though used in racist contexts in the latter half of the nineteenth century, continued to circulate to shape the ways adults thought about childhood. His poems became the first of their kind to both represent black middle-class values as well as to present black heritage to children.

My conclusion re-evaluates the early African-American canon to argue for the need of reception histories. The scholarship that created foundational research on social and material conditions of race orchestrated many studies to dismantle a call for post-racialist research. My conclusion argues that now more than ever there is a need to reanalyze the African American literature canon with attention to print culture and reception. 


\section{Chapter 1: On Wheatley: The Children's Literature Poet}

"She has left behind her a small volume of poems, as a rich legacy to our race" - Freedom's Journal, November 2, 1827

First published in London on September 1, 1773, Phillis Wheatley's Poems on Various Subjects, Religious and Moral stirred the interests of not only English abolitionists across the Atlantic, but many American abolitionists, along with editors of printed ephemera. The occasion of Wheatley's published verse stirred American masses to consider Wheatley as "a Negro girl" genius, especially as editors collected pieces of her oeuvre and situated them among the works of other African American writers and intellectuals. Wheatley gained celebrity status as her reputation as a "Negro girl" genius spread rapidly during her writing career from 1767-1784 (Young 209). Even after her death in 1784, debates about Wheatley's genius continued over two decades (Gundaker 653). Scholars have duly noted that Wheatley's poetry appeared in abolitionist newspapers, religious pamphlets and broadsides, as well as pro-slavery newspapers. ${ }^{1}$ In fact, many who trace her circulation history conclude that abolitionists appropriated her poetry to showcase her achievements, which, abolitionists argued, necessitated abolition and equal rights for African Americans. ${ }^{2}$ However, among the many contexts in which Wheatley's poetry

\footnotetext{
${ }^{1}$ For an extended analysis of Wheatley's marketability, see Jennifer Rene Young's dissertation entitled, Marketing a Sable Muse: The Cultural Circulation of Phillis Wheatley, 1767-1865. In regard to proslavery newspapers and arguments, see Washington D.C.'s National Intelligencer and Bernard Romans's A Concise Natural History of East and West Florida.

${ }^{2}$ See Leif Eckstrom's Untimely Verse: Distressed Publishing and Exemplary Circulation in Antebellum America 28. Also, see Jennifer Rene Young's Marketing a Sable Muse 3. Young
} 
appeared, school magazines and texts for black children with a secondary concern with nature and black freedom continue to go unnoticed or understudied by scholars despite their production. These texts show that many editors, especially in the early nineteenth century, found childhood a vehicle through which to uplift black Americans.

Wheatley's circulation history tells a story about the ways early nineteenth-century readers and editors repurposed her poems, the ways twentieth-century editors promoted her legacy, and how twenty-first century editors and scholars formalized a mode of reading her verse through the context of her captivity and limited network of white patronage. More particularly, Wheatley's appearance in children's magazines signaled the beginnings of uplift strategies that made children necessary participants in a slave economy. However, their participation granted conditional citizenship. Courtney Weikle-Mills explains that early American theories of free citizenship were tied to "the idea that children, implicitly white and male, were 'born free' (24). She explains that this theory underpinned "American Revolutionary arguments for independence and popular sovereignty" (24). Weikle-Mills continues:

claims her dissertation is the most extensive of Wheatley's career success, though she doesn't take into account Wheatley's poems circulating in black editors' newspapers and collections for education and an ex-Quaker's children's magazine. Wheatley's posthumous career within these publications signal that her work was valued in multiple ways other than for their use value in “the political debates on slavery,” which Young argues, “kept Phillis Wheatley’s poetry in circulation" (74). Young also dismisses Donaldson's publication all together in chapter four of her dissertation where she explains, "Her [Wheatley's] last appearance in the American newspapers was in 1796 in the Methodist Magazine" (94). 
Politicians frequently commented that the freedom of the emerging nation depended on children's education as virtuous, self-policing citizens. Preparing young people to exercise liberty, while also training them in submission, was the raison d'être for many early American children's books. (24)

To be unfree went against Revolutionary rhetoric and contradicted the very principles that the emerging nation accepted. Therefore, early abolitionists who supported gradual manumission found some success in arguing for the need to educate black children to become responsible agents in society. One example, Arthur Donaldson's Juvenile Magazine $(1811,1813)$, was expressly created for the betterment of black families, and especially black children. During a time when harmful stereotypes of black children had not yet surfaced, black children learned to read Bible scriptures so that they learned virtuousness. Donaldson's magazine attests to the ways he formulated local child citizenship for black children, so that they could attain a degree of liberation for their futures.

Excavating the varied uses of Wheatley's poetry involves consideration of the historical context as well as an attention to possible uses of her poetry. Throughout much of the latter half of the eighteenth century, the United States embarked on defining what independence meant in a fractured and underdeveloped economy with largely rural populations. In 1789, the inauguration of the federal government under the U.S. Constitution signaled the emergence of a collective nation. Literature as a cultural force provided an answer for managing cultural anxiety surrounding a burgeoning republic. Within this context, booksellers in the early republic sold and printed material that brought disparate publics together as one. They saw their efforts as part of the work of a new nation. Abolitionists, especially those circulating Wheatley's poetry, saw their 
work in a similar vein. Circulating Wheatley's poetry on morality proved useful for bringing the nation together on the slavery question.

As the nineteenth century continued, black editors circulated Wheatley's poetry for racial uplift. Kevin Gaines notes that racial uplift during the emancipation period signified collective social aspiration, advancement, and struggle (xiv). Racial uplift ideology had not taken its more familiar form of racialized elite identity for upper-class blacks. Editors used Wheatley's more challenging and neo-classical poems to emphasize educational opportunities for black children. For instance, the first black periodical, Freedom's Journal (1827-1829), published "On the Death of J.C. an infant," "An Hymn to the Morning," and "A Hymn to Humanity" in one of its 1827 issues. Each poem features complex words, heightened forms of language, and neoclassical references that editors could recycle to speak for an uplifted community. Black children's recitations of the poems showcased their intelligence and challenged stereotypes that belittled their mental faculties. Many uplift ideological supporters believed that education granted blacks freedom and liberation in white society. Wheatley's poems appropriated Anglo-American ideals and traditions, which were tantalizing for editors who wished to instill self-reliance and selfimprovement in a fledgling black community.

By mid-nineteenth century, the ills of slavery waged on and many white men and women grossly stereotyped children as insensate pickaninnies. Robin Bernstein explains that the pickaninny was "a black imagined subhuman juvenile who was typically depicted outdoors, merrily accepting violence” (34). Like Freedom's Journal, black and white editors created collections that challenged representations of black people. Namely, William Wells Brown's The Black Man (1863) and Lydia Maria Child's The Freedmen's Book (1865) circulated “On the Death of a Young Lady" and "Thoughts on the Work of Providence" respectively to encourage 
children to consider imaginative liberalism. Though the constructions of black childhood in white society stifled success, these editors found ways to use Wheatley's poems as sites for attempting liberty.

By the early twentieth century, Wheatley's importance faded as New Negro critics pushed for a new black aesthetic. New Negro critics sought poetry that spoke specifically for black experiences. That is, the western literary traditions no longer fully represented the unique experiences of black Americans. The Harlem Renaissance, therefore, used black folk traditions to orchestrate a new era of black representation and art. Many black writers of the period mixed western traditions with black experiences to usher in unique styles of black expression. The legacy of creating unique art continued into later periods. Wheatley's poetry during these time periods fell further from public view.

After the recovery work of feminists in the late twentieth century, Wheatley's work gained more attention. The impetus to formulate a black literary tradition caused many editors to reach back to Wheatley as the earliest black poet. However, her reputation took a hit from New Negro and Black Arts Movement critics as they sought literature less engaged with western styles of writing and more engaged with black consciousness. Vincent Caretta and John C. Shields rectified her image and gave her poems new interpretations as scholars worked to understand Wheatley's social and material conditions. After their collections and biography, scholarship devoted more time to understanding the conditions in which Wheatley wrote. Today, Wheatley represents the beginning of the African American literary tradition. Though she is not the first published black poet, classrooms and editors often depict her as such. Despite the fame she garnered posthumously, there are histories that remain forgotten because we've chosen to 
celebrate only the categories we recognize as significant. What is left out of conversations are the ways Wheatley influenced child readers posthumously.

Wheatley's poems circulated in children's magazines and black newspapers concerned about family education in the early nineteenth century. This legacy is often understudied, even though it continued into the twentieth century. More importantly, how editors and readers chose her poems for imagined child and adult audiences speaks to the forgotten "uses" of Wheatley's poetry. Poems in the nineteenth century, as Michael C. Cohen relates "occupied a complex position in the history of social life and sociality" (Cohen, Social Lives 9). Excavating the varied uses of Wheatley's poetry widens understanding of their centrality in forgotten early nineteenthcentury uplift publications geared specifically for black youth, exposes the dual subjectivity of black youth in northern states, as well as lends to a secondary concern with nature and childrearing. However, because the resolve of scholarship to represent how blacks advocated for themselves often follows a single trajectory, scholarship on Wheatley has neglected these important lines of circulation. Scholarship that centers on the agency and resistance that Wheatley's poetry presented has shaped much of the contemporary ways scholars approach her oeuvre. ${ }^{3}$ The ways abolitionists used Wheatley in and outside of the classroom are forgotten in lieu of responding to only the adults who resisted hegemony.

\section{Wheatley as a Children's Author}

A failure in newspaper publishing propels this first chapter. It deserves to be studied in its own right because it shows the ways failures created possibilities for black mobility. Many who

\footnotetext{
${ }^{3}$ For more information on scholarship that addresses Wheatley's agency, please see John C. Shields, Henry Louis Gates, Jr., and Joanna Brooks' "Our Phillis, Ourselves.”
} 
began magazine publishing in the early nineteenth century certainly knew its foreboding failure. Arthur Donaldson, an ex-Quaker who began a school for black children as early as 1809, feared his venture with his Juvenile Magazine $(1811,1813)$ was doomed to failure in the very beginning. He relays his financial crisis to his audience, begging for their subscriptions to keep his magazine afloat. Donaldson wanted subscribers to empathize and create emotional bonds with the material and with human subjects that he described. Among the material were additions of Wheatley's poetry that, in the given context, spoke for and to black children. His magazine not only sought the "truth" for its readers, but it recognized the need to connect local readers to an early imagined black network that connected the deceased with the living.

On August 1, 1813, Phillis Wheatley began her posthumous journey as a children's author for Donaldson's Juvenile Magazine (1811, 1813). Donaldson began his school for freed black youth in Philadelphia as early as 1809. He repurposed four of Wheatley's poems from Poems on Various Subjects (1773). Each poem attested to Donaldson's vision for an educated and uplifted community of freed people, though his biases often got in the way of his intention. Donaldson wrestled with granting African Americans space to write and read from texts about them (not always from them) yet, he subordinated them to the tenets of Christianity. His paternalism subjected his students to oppressive understandings of their identities. These magazines are overlooked because of their participation in a culture that limited African American voices. However, simply labeling them as such without examining the liminal spaces that they provided youth and adults of color dismisses the dynamics of the instability of print culture. The constructions and political structures of race reveal degrees of freedom that are overlooked when focusing on one form of agency that privileges adult resistance. Donaldson's magazine provides a view, if only for a second, into the educational practices of freed black 
youth in early nineteenth century Philadelphia. Many histories on Quakers and schooling only devote a few passages of Quaker education and freed schools. ${ }^{4}$ Thus, my undertaking of this study will be based upon evidence from Donaldson's magazine, general histories of Quakers, and the Friends' meeting notes.

Arthur Donaldson taught literacy and uplift to black children when doing so threatened the social order that laws in the late eighteenth and early nineteenth centuries sought to establish. Though any act of educating and uplifting freed peoples in the early nineteenth century was risky, the shape of Donaldson's uplift education often held overtones of white privilege. Within this paradox of free to think but only within set boundaries, black youth's education may have seemed hopeful to them, but bleak to us. Nevertheless, it was a start. Forbidden to write, enslaved blacks as Jennifer Monaghan relates, were only taught to read in the colonial period (243). During a time where Pennsylvania passed the nation's first gradual manumission law in 1780, freed black youth found themselves faced with limited educational opportunities. (Wolfinger). Additionally, "as gradual abolition and immigration of manumitted slaves from the South increased the free African-American population in cities such as New York and Philadelphia, white hostility intensified" (Bacon, The Humblest 15). The legacy of laws that forbade blacks from writing namely in the south and held them in bondage in Pennsylvania even into the early nineteenth century hindered educational opportunities for blacks. ${ }^{5}$ Donaldson, who

\footnotetext{
${ }^{4}$ See William Wistar Comfort's The Quakers: A Brief account of their Influence on Pennsylvania.

${ }^{5}$ Monaghan explains that writing instruction was banned in South Carolina and Georgia in 1740 and 1755 , respectively.
} 
published The Juvenile Magazine in 1811 and again in 1813, situated his children's magazine in Philadelphia, where he developed a school specifically for black children. ${ }^{6}$ Donaldson, once a member of the controversial Philadelphia Society of Friends, used Wheatley's poetry to enlighten many freed black children to create and write, the former idea generally not supported in Quaker-ran schools for freed black children. ${ }^{7}$ More specifically, Donaldson repurposed Wheatley's “On the Death of J.C. an Infant," "An Hymn to the Morning," "To the Right Honorable William, Earl of Dartmouth," and "Goliath of Gath" to encourage his child readers to transcend their current stations in life - what I call imaginative liberalism.

The Society of Friends taught blacks to read, write, and cipher so that they could be productive members of society even when doing so threatened the social order. ${ }^{8}$ Schools taught these rudimentary skills to white children in the early to mid-nineteenth century (Schweiger 550). Quakers believed that because God was accessible to all people, it was their mission to impart knowledge upon oppressed peoples. Anthony Benezet, who famously organized some of

\footnotetext{
${ }^{6}$ In 1812, Donaldson's school caught fire and the effects of which prevented him from publishing that year.

${ }^{7}$ Most religious schools sought to teach enslaved black children how to read scriptures of the Bible for their moral upbringing. However, individual efforts to teach black children to write can be found in Anthony Benezet's school for freed children. See Monaghan's “Literacy Instruction and the Enslaved" from Learning to Read and Write in Colonial America 244 and 267.

${ }^{8}$ Gary B. Nash explains that Philadelphians opposed levying their taxes to pay for poor black children's education around 1809. Furthermore, “although further legislation in 1912 and 1818 established a system of public schools...the exclusion of black children continued" (208).
} 
the first schools in Philadelphia, organized a meeting for non-slaveholding Quakers in Philadelphia around 1775 and formed the Society for the Relief of Africans Unlawfully Held in Bondage. The society was later reinstituted as the Pennsylvania Society for Promoting the Abolition of Slavery and for the Relief of Free Negroes Unlawfully Held in Bondage (PAS) (Polgar 238). PAS became one of the most influential antislavery societies of its age (Polgar 238). PAS was one of the first societies that supported black teachers teaching black youth. However, in 1789, they felt that black teachers were too lenient with black children and therefore, withdrew support from black teachers (Nash 204). Black teachers later formed their own schools in their homes or churches. Nevertheless, after 1799 in Philadelphia, attendance in freed black schools taught by white and black teachers declined. PAS speculated that one cause was white masters who weren't allowing their black apprentices off work for school (Nash 225). In 1805, PAS stopped promoting schooling among black youth in their annual address to people of color and instead, emphasized labor and apprenticeships (Nash 205). Eight years later when Donaldson had established his school for freed black youth, attendance had fallen slightly from 426 to 414 . Educational support for black children waned by the time Donaldson established his school. Prospects for black youth were grimmer by the second. Even in 1812 when legislation was finally passed to subsidize poor white youth in Philadelphia for education, black children were excluded (Nash 426). Many questions loom over Donaldson's decision to create a school for black youth — why did he develop one even though PAS created several schools for freed black youth in Philadelphia? Did he not believe that his school could fail, given the examples of PAS's unsuccessful attempts at drawing in more freed youth? Perhaps Donaldson felt his instruction differed from PAS's earlier attempts at education. 
One way to view Donaldson's choice is to understand that PAS's instruction did not emphasize levels of freedom in the ways that Donaldson's instruction did. Donaldson's Magazine featured "pieces in process and verse" that were "religious, moral, and entertaining," yet also appealing to black readers in all stages of reading and writing development (Donaldson 1). Even Donaldson, who found "something wanting” from different denominations' efforts to educate black children, looked to "pious authors" and the "Scriptures of Truth" to teach children to read and write (Donaldson 1). This early nineteenth-century children's magazine was unique in its approach to both moralistic values and entertaining content ${ }^{9}$ Printed so that, according to Donaldson in his "Address to People of Color," "you [people of color] might be able to read good books, and above all the Scriptures of Truth...," it featured pieces from English poets and borrowed material from its predecessors to teach a form of uplift to black youth (Donaldson 1). Donaldson carefully introduced the idea that blacks should use this magazine for reading purposes, even though several of the texts included in his magazine and school indicated use for writing instruction.

Unlike earlier child magazines of the late eighteenth and early nineteenth centuries, Donaldson's represented an early networking site where black women writers contributed. Donaldson included letters and poetry from black writers, including Mary Perth, a runaway from Virginia in 1776, who wrote a letter to her friend in Scotland in 1797 (Pybus 34). He also included a poem, which he declared was “composed by a woman of colour" (Donaldson 49). It should be understood that both texts written by black women featured overtones of morality and

\footnotetext{
${ }^{9}$ Other children's magazines included Children's Magazine (1789), Miscellaneous Repository of Useful Information (1802-1803), Juvenile Ohio (1802), and Juvenile Portfolio.
} 
concede to Quaker ideology, which often held overtones of paternalism. However, the inclusion of black women's voices in a magazine intended for black readers (both young and old) sets an early precedent of establishing their credibility to speak and write in early nineteenth-century periodical culture. A closer look at Wheatley's poems and the context in which Donaldson placed them shows the ways his school imagined how black youth could transcend their stations through literature. On the surface, Donaldson's heavy moral tones in the selections of his magazine indicated his participation in a system that placed blacks in a servile role, which has led scholars to gloss over his efforts. However, the inclusion of Wheatley's poetry complicates that narrative.

In the preface of his first issue, Donaldson explains his aims for seeking "truth." Donaldson writes, "Anything that I may insert in this Work, I hope always to have an eye to this text, 'What is Truth' and shall endeavor to admit nothing but what can be supported thereby" (Donaldson 1). “Truth" presents dual meaning in this context—on the one hand, Donaldson relays his aspirations of seeking truth through scripture, but on the other, finding truth through illuminating "their[blacks] benighted understandings" becomes the upmost importance to this exQuaker. Donaldson explains that through his "knowledge of their [blacks] situation, on account of learning...," he is better equipped to provide them an illuminated understanding. He focuses on the environmental factors that play a role in blacks" "benighted" learning instead of solely relying on racial science..$^{10}$ Being an outcast himself, he finds commonality with his readership by explaining he, too is not a member of any religious society but relies on scripture as his

10 Theories of racial science, according to Britt Rusert circulated into scientific metropoles such as Philadelphia and were used to show distinct physical lines that separated races (293). 
guide. ${ }^{11}$ Rhetorically, he separates himself from the Society of Friends, which cultivated distrust in the early formations of free schools for black youth. Donaldson skillfully positions his ephemeral text as a guide to understanding black youth as well as a tool for black youth to use to seek "truth."

Donaldson emphasizes Wheatley's age when stating her accomplishments, pointing to her absorption of the Latin language: "Passionately fond of reading, and delighting in the perusal of the scriptures, she rapidly attained knowledge of the Latin language. In 1772, at nineteen years of age, Phillis Wheatley, the negress slave, published a little volume in English..." (Donaldson 19). Donaldson reprints most of Wheatley's biography from Henri Grégoire's De la litterature des Negres (1808), which was translated into English two years later and entitled, An Enquiry Concerning the Intellectual and Moral Faculties, and Literature of Negroes..$^{12}$ To emphasize her prodigal nature as well as her age imparts reflection, but at a cost. Donaldson is aware of his

${ }^{11}$ According to Ancestry.com Library edition, The Society of Friends' meeting notes in 1808 explain that "Arthur Donaldson has been treated with by the overseers for engaging in business beyond his ability to manage, in conducting which he has fallen short in the payment of his just debts-10 Mo. 17-1808." This page is categorized under "Marriage." Also see the May 2, 1809 note, which relates that "Our labours of love being thus slighted... it becomes a duty to testify, as we hereby do, that we no longer consider the said Arthur Donaldson as retaining a right of membership amongst us..."

12 See Thomas Cassirer and Jean-Franois Briére's On the Cultural Achievements of Negroes (1996). They mention that Grégore's book “was a touchstone for nineteenth-century abolitionists...in the United States" (back cover). 
pupils' environment and social strictures; asking that they reflect on a former slave's capabilities when laws on slavery were less hardened is bold. Wheatley then became a symbol and icon who was impossible to imitate, yet, also inspired black youth to strive for attainments beyond their reach.

Several of Donaldson's inclusions feature religious and moral pieces, a tradition that harkens back to the early colonial period and lends useful material for uplift education. Like PAS Donaldson worked with the idea that a moral education lead to a virtuous life for blacks and "persuade[d] a skeptical and prejudiced white American public to extend egalitarian promises of Revolutionary ideology to the nation's African Americans" (Polgar 230). The problem with the 1780s gradual manumission law was that it granted gradual freedom without a foundation for helping former enslaved people adjust to an exclusively white society. The rhetoric of respectability ensured Quakers and Donaldson that blacks too could aspire to being useful agents in a society that limited their agency. Within this context, Donaldson felt assured that temperance, obedience, and moral obligation ensured their productivity and conversely stifled prejudice toward black Americans. Wheatley's poetry made possible recycled eighteenth-century tenets of obedience, morality, and education to instruct black youth. Yet, considering Donaldson's disassociation from the Society of Friends, he found a deeper truth within her poetry that enabled black youth to imitate a form of uplift for blacks. This is evidenced in one of the poems he includes. "A Hymn to the Morning" emphasizes more than morality - it combines classical education (often taught specifically to upper class white families) with an appreciation for nature. Both subjects, taught to upper class white children, were now in the possession of freed black children. The very beginning of the poem draws inspiration from "the honour'd nine" which in classical literature represents the goddesses of the arts (Mallory 22). Donaldson, by way 
of Wheatley's poetry, encourages black children to seek divine inspiration through communion with nature. This important connection, though not emphasized in the Society of Friends' schools, reveals the ways Donaldson imagined black mobility in ephemeral contexts.

In the poem mentioned previously, the narrator emphasizes creation and inspiration through the dawn (Wheatley, "A Hymn to the Morning" 56). Strong themes of nature and creation imbue the spirit of Wheatley's poetry, further representing the body's connection to nature. For instance, in the third stanza, the narrator iterates: "The bow'rs, the gales, the variegated skies/ In all their pleasures in my bosom rise" (Wheatley, "A Hymn to the Morning" 56). Within the heart, the narrator feels protected and inspired by the elements of nature- the shading from the trees and the winds from the sky-elements that, consequently ignite "the pleasing fire" that Calliope's sisters fan. Teaching Wheatley's verse to black children exemplifies how they, too, can think through the body in ways that allow degrees of freedom to create from their imagination and from the natural world.

Donaldson's connection to nature and children reaches back to an early theme that emerges from early children's magazines. Donaldson, who borrows from the Juvenile Magazine, or Miscellaneous Repository of Useful Information, an 1802 children's magazine which featured texts on natural history, takes cues from this early strand of childhood education to reach out to black youth. The idea that natural history is a useful tool to teach children is a theory purported by French philosopher Jean-Jacques Rousseau and even John Woolman, whose journal shows the influences his time in nature had on his education. ${ }^{13}$ These figures influenced editors of early

13 Woolman was often a proponent of animals' right. 
childhood magazines. By reapprorpiating Wheatley’s “A Hymn to the Morning,” Donaldson found ways to recycle early natural history as a source for black childhood instruction.

In the opening stanza, not only are readers introduced to the Greek goddess Aurora, but to the bright rays which demand the narrator's song. From the beginning, the dawn requests that her pupil, the narrator, comply to her instruction. The narrator, embodying a child-like demeanor, complies and begins to "sing" while the zephyr, or gentle breeze, sings along with the narrator while enlisting the leaves as its instruments. The narrator and nature become harmonious, both using objects from nature-“ev'ry leaf," the morning's extended rays, and even the "feather'd race" - to derive inspiration. Within the second stanza, the narrator and nature become of one harmony and by the third stanza, nature envelops its muse, protecting her from its own power. It is at the following line in the third stanza where the narrator invokes Calliope, or the muse of epic poetry to "awake the sacred lyre" (Wheatley, "Hymn to the Morning" 239). The narrator, drawing from Calliope, her source of power, creates harmony that she likens to "bow'rs, gales, the variegated skies." Before, the skies were vaulted; now that nature and the narrator are one, color syncopates with their song and gathers from the bosom of the narrator. The narrator ends with intense feeling and inspiration for her newly found voice, though it appears to be "too strong." Without feeling like the narrator has begun, she must end on a discouraging note. The feeling of discouragement after failure or of having desires to create but having impediments that one cannot control concludes the final stanza. This message, the desire to create from one's experience or inspiration but being prohibited from doing so, resonates with Donaldson's pupils. Creation, both within nature and within oneself, holds power but can be stifled from uncontrollable forces. The first line of the very last stanza implies the influence or "radiance" of an illustrious king from the east becomes too strong. Though her metaphor is 
intended for Britain's rule, one could easily affix the message to newly freed black youth in Philadelphia who similarly, cannot awaken their inner strengths because of outside influences who keep them from doing so.

In Donaldson's May 1, 1811 issue, he situates William Cowper's “Christian Freedom” among many publications related to slavery, exceptional, and obscure African-American writings. With themes of freedom and nature coupled with race and class, Donaldson imagines a space where these themes clash and speak to freed black youth who may not be bound by physical chains but cannot move socially. Similar to Wheatley's "An Hymn to the Morning," "Christian Freedom" shadows a slave who devotes his time to imagining freedom through the "delightful scenery" of nature. Though the poem alludes to class - "those whose mansions glitter in his [the slave's] sight," it places emphasis on one transcending race and class through communion with nature: "His are mountains, and the vallies his, / And the resplendent rivers" (Donaldson 26). The slave in the poem gains an imaginative liberation, which materializes as “wings, that neither sickness, pain,/Nor penury, can cripple or confine.” Much like the wings of the bird in Wheatley's poem, they represent freedom to move beyond physical degradation into spiritual realms. Placing emphasis on self-fulfillment through communion with "his Father's work," Cowper introduces readers to the Romantic ideations of nature's integral role in creativity and imagination. For Donaldson, situating Cowper's poem amongst histories of Benjamin Banneker foregrounds Romantic playgrounds for black youth's imagination to soar.

Using underlying themes of nature and children from Wheatley's poems, Donaldson repurposes "On the Death of J.C. an Infant" to teach a mode of freedom that one can paradoxically experience through the body and from the body. The poem begins with a departure from nature: "No more the flow'ry scenes of pleasure rise,/ Nor charming prospects greet the 
mental eyes" (Wheatley, J.C. an Infant” 19). This departure signals a separation from earthly beauty to celestial beauty that doesn't encompass nature. In previous poems within Donaldson's magazine, nature becomes a tool for readers to use in order to escape boundedness. However, within this poem death signifies a transformation in power. For instance on earth, the body of the infant is like "a branch that from the tree is torn,/ Falls prostrate, wither'd, languid, and forlorn." Like a branch torn prematurely from its host, the infant's life is cut short by an ineffable power. However, the angel responds to the parent's question that the baby is now “in heav'n's high palaces" indicating that "his wings" has carried him to higher domains. If anything, this poem relays that death is nothing to fear and is a transformation from an earthly body into a divine existence. Black children born without the resources as white children, were closer to experiencing indirectly the effects of death; ${ }^{14}$ Donaldson repurposes Wheatley's poem to instill a sense of faith in something more powerful than they to teach hope in troublesome times.

Wheatley's epic poem, “Goliath of Gath,” provided a way for Donaldson's students to relate to the "underdog" message hidden within the poem. This poem, though originally read by adults upon its publication, is easily recognizable to many readers of the Bible (I Samuel, 17) and also for its child-hero. Beginning with her customary elaborate invocation to her muses, Wheatley prepares her readers for the "dreadful scenes and toils of war." Donaldson, aware of

14 The yellow fever epidemic of 1793 in Philadelphia had serious effects on blacks who served as nurse to whites. See Jacqueline Bacon 16. Also, many blacks did not have access to the same resources that sustained whites during the early nineteenth century as blacks were segregated and forced to work menial jobs. For a discussion of Philadelphia's poor black population and their access to resources, see Nash's Forging Freedom. 
her poem's entertainment value, includes it in his repertoire to encourage readers to reap its underlying message of tenacity. David, who famously slays the prideful Goliath, represents the will and determination that comes from sheer blind-faith in one's abilities. Wheatley describes Goliath as an armored giant who instills fear into "David's race." However, David's intellect and courage makes him the best candidate for ruling over the "children" of Israel. Young black children, some born into freedom and others from families newly freed in Philadelphia in the early nineteenth century, not only identified with poems about youthful heroes, but recognized the personification of tyranny suppressing their freedom. Wheatley's slave positionality and her interpretation of the well-known child-hero and giant offers black women and children a way to interpret their status in a predominantly white society which constantly threatened their free status.

The young Sarah Mapps Douglass (1806-1882) who attended Donaldson's school from 1809-1813 was well aware of racism even as a child and better understood the implications of Goliath's reign (Bacon, The Humblest 29).${ }^{15}$ In her address directed to The Female Literary

${ }^{15}$ See Douglass's letter to William Bassett found in William Bassett's Society of Friends in the United States (1840) where she laments the treatment her and her mother received from other Quakers during one of the many Society of Friends' meetings. It was not uncommon to have segregated benches in the Arch Street Friends Meetings in Philadelphia where she and her mother, Grace Douglass attended. Sarah Mapps Douglass explains that the "Negro Pew" was set aside in the back of the Friends' meeting houses where only Friends of color could sit. White Friends bookended each end of the pew to prevent white Friends from sitting in that pew. 
Association (a society she helped form), she presented her position on oppressive laws (possibly the Fugitive Slave Act of 1793) during the 1830s:

But how was the scene changed when I beheld the oppressor lurking on the border of my own peaceful home! I saw his iron hand stretched forth to seize me as his prey, and the cause of the slave became my own... One year ago, I detested the slaveholder; now I can pity and pray for him. (Ripley 117)

Based on Douglass's expansive literary education, she quite possibly draws from imagery and symbols from Wheatley's poetry to encourage her fellow freed black women members to fight against slavery. Douglass, however, places the personified oppressive entity just right outside of her domestic and peaceful space. Like Wheatley, Douglass invokes the peace and virtuousness of her establishment; however, the entity metaphorically lurks on the border of her home. She reinvents the pastoral form in her speech to suit a more urbanized understanding and nineteenthcentury envisioning of the oppressive "monster" that lurks from the field to the home. Drawing from Wheatley's Goliath, Douglass paints a vivid closeness of this entity that threatens the domestic space of her and her fellow black women. This intimate and unwelcomed presence creates anxieties and propels black elite women to help less fortunate black people who are subjected to slavery. "Goliath of Gath" offers an articulation of an oppressor which forms Douglass's understanding of an abstract power. Using this interpretation, Douglass is better able to connect her experience to those enslaved and to help her peers empathize with less fortunate members.

"Goliath of Gath," becomes a poem that was used for reflective purposes, but also to represent uplift for children. Within the poem, David uses a "forceful pebble" to conquer the heavily armored giant. This vivid and intense scene shows the stone penetrating through 
Goliath's skull and shattering his brain. A dramatic murder connects the hidden message behind the insubstantial pebble - with the backing of "Jehovah's name" and grace, one can conquer a well-equipped giant. For freed black youth, the pebble stands for a metonym for their underestimated abilities to fight against oppression. One of the many arguments that many opponents of abolition advanced was the lack of intellect among blacks. Thomas Jefferson's position on black's intellects advances this sentiment:

Comparing them by their faculties of memory, reason, and imagination, it appears to me, that in memory they are equal to the whites; in reason much inferior, as I think one could scarcely be found capable of tracing and comprehending the investigations of Euclid; and that in imagination they are dull, tasteless, and anomalous. (202)

Donaldson, well aware of these arguments, ${ }^{16}$ uses Wheatley's poem to subtly suggest the influence black youth can possess. Though they may be young like David, they are still "So great in prowess" (Wheatley, "Goliath" 31) and can destroy the entity that seeks to enslave their physical and mental capabilities. Yet, while this message could certainly serve as one

${ }^{16}$ Donaldson includes an excerpt of David Bailie Warden's Enquiry concerning the intellectual and moral Faculties, and literature of Negros in his August 1813 issue. This edition is a poorly translated version of Abbe Grégoire's De la litterature des negres (1808), but it refutes Thomas Jefferson's argument about blacks' intellectual capabilities. Additionally, Jacqueline Bacon lists the unfair treatment that blacks received at the hands of whites in the early nineteenth century and how the overpopulation of blacks in prison was often used as evidence of their "degraded" status. See Freedom's Journal: The First African-American Newspaper (15). 
interpretation of the poem, the poem's attention to obedience drives another purpose for its use. Goliath rebels against divinity which leads to his demise. While the poem centers on the climax of David and Goliath's battle, it also draws readers' attentions to Goliath's pride. Also, given Goliath's name in the title, Donaldson sees how it could focus his readers' attention to what happens when they disobey their masters. Goliath's pride ultimately stands in the way of his victory. Donaldson is no stranger to this concept and includes many texts with similar moral messages. He cautions his youthful readers to respect their parents, masters, and the white men who benevolently aid them. Donaldson's choice in selecting this poem reflects his idealization of black youth's subjectivity while also exposing how his desires were rooted in anxiety over black citizenship and society's fear of the fate of the U.S.'s relation to freed blacks.

"To the right Honourable William" has in recent years become one of the most canonized poems mainly for its subtle critique of slavery. Donaldson repurposes it for children, giving it a different meaning in relation to "An Hymn to the Morning," "On the Death of J.C. an Infant" and some of "On being Brought from Africa to America.” From Wheatley's oeuvre, Donaldson chooses to include "To the Right Honourable William" and situates it among poems about nature and child death. The physical placement of these poems adds context to its (re)purpose - Wheatley becomes the voice of children imploring the Earl of Dartmouth to understand "from whence [her] love of Freedom sprung." She explained, "I, young in life; by seeming cruel fate/ Was snatch'd from Afric's fancy'd happy seat." Wheatley, by way of flashback, returns to her youth to confront the evil of slavery. She extends this child-like persona to envision how her parents felt: "What sorrows labour in my parents' breast?/ Steel'd was that soul, and by no misery mov'd,/ That from a father seized his babe belov'd." Freed black children only being somewhat removed from slavery could recount stories from their parents or 
grandparents who were themselves enslaved. This poem functions as a form of collective history and memory, reminding black children of their heritage ("from Afric's fancy'd happy seat") and the suffering that their ancestors endured. This image carries a legacy that black children could take with them and provide a source of power.

\section{Wheatley, Freedom's Journal, and Circulation before Reconstruction}

After these poems' first appearances in the Juvenile Magazine, Wheatley's poems continued to circulate up to the Reconstruction era. In 1827, Freedom's Journal (1827-1829), the first African-American owned newspaper in New York City, New York printed these same poems with the addition of "A Hymn to Humanity" and the exclusion of "Goliath of Gath." The editors included lines 9-18 from "On the Death of J.C. an Infant," lines 5-10 of "Hymn to the Morning" and all of "Hymn to Humanity.” John B. Russwurm, one of the founders of the newspaper, placed much value on reading and writing for black empowerment (Partin). Russwurm and Samuel Cornish hoped that their newspaper encouraged literacy and intellectual development among African Americans. They infused elements of eighteenth-century environmentalist and romantic racialist rationalizations throughout their newspaper according to Cristin Ellis (40). Within this context, Wheatley's poems reflect black editors' attitudes about uplift, black education, and moral degradation for both child and adult readers.

Wheatley's poetry served the purpose of uplifting black children from moral and social degradation through Freedom's Journal. Evidence of the newspaper's influence and indirectly, the editor's purpose with reusing Wheatley's poetry is captured in the November 9, 1827 issue. In this issue, Russwurm published a thank-you note from Charles C. Andrews who taught at the African Free School, No. 2. Andrews attests that "much good may be calculated to result from such a journal being perused by such readers, as will have access to its pages" (Russwurm). 
Within this thank-you note, Andrews acknowledges Russwurm's efforts in regularly giving the "Library in the School in Mulberry street" copies of Freedom's Journal. Andrews explains the benefits of the newspaper to black children:

One of the little scholars, aged about ten years, was questioned on some astronomical and other scientific subjects a few months ago, by a celebrated and learned doctor of this city; the boy answered so readily and so accurately to the queries, was at last asked, how it was that he was so well acquainted with such subjects? His reply was, that he remembered to have read of them in the books of the School Library. (Russwurm)

Attesting to the newspaper's influence, Andrews' note indicates the value of the newspaper's circulation in black schools of New York. More importantly, the note expresses appreciation for the 10-year-old's educational uplift through the practice of reading in the library. Readers gather that Russwurm's publication places them in equal footing with a "celebrated and learned doctor of this city." Both of Wheatley's hymns appear in this same issue and affix themselves within this context of social and moral uplift. This placement reflects one of Russwurm's ultimate purposes - to teach children to uplift themselves through reading moral poetry. Russwurm's affinity for moral and intellectual uplift for not only adults, but children is also evidenced in the 1827, March 23 issue entitled, “Anxiously solicitous for the well-being of our brethren.” Russwurm states his intentions for uplift:

It is our duty and privilege, by the faithful improvement of all the advantages which we possess, to convince a Religious and Republican nation, of the importance and policy of raising us in the scale of being. It becomes us, therefore, 
never to neglect any of the means of education within the reach of ourselves or children. (Russwurm)

Given Wheatley's attention to classical literature in “An Hymn to Humanity," and its heightened language, her poem served the purpose of uplifting black children using a classical education. Wheatley's knowledge of Latin and the classics secures for Russwurm the reputation he seeks for his journal. His ultimate goal was to teach black adults and children uplift and "never to neglect any of the means of education."

“An Hymn to Humanity” within Russwurm’s and Cornish’s publication extends readings of this classical epic hymn. Traditionally read for its Christian messages, "An Hymn to Humanity" has received criticism for being derivative of Alexander Pope's poems. However, Maureen Anderson reads this poem in a new light_offering insights into Wheatley's subversive classical references and how they undergird her critique of a forming American identity. Anderson argues that Wheatley presents her understanding of Virgil's The Aeneid through the voice of Dido, "the Afric queen" to critique "her contemporary Early American audience with the travesty of their dismissal, cruelty, and crimes against humanity" (Anderson, "Phillis Wheatley's Dido" 5). Anderson's reading of the classical allusions opens doors to investigating what it meant for black children to learn classical education from the reference point of a newspaper for and by black people. Extending this reading even further begged the questionwhat might Wheatley's allusions to classical references mean for black children's education?

For one, Wheatley's poem inspired black children to open closed minds in white society and to break away from constraints that hindered their progress. Similarly, in Virgil's myth, Aeneas' charge from his mother Venus was to create Rome and to allow freedom of thought, which inspired the nation to flourish. Wheatley was knowledgeable about Virgil's text and 
Anderson explains that:

...considering Wheatley possessed knowledge of both the Aeneid and of the American identity with the Aeneas myth, her message is not one about one man's desire and dismissal of a woman, but rather about those who subjugate others through slavery, particularly her African brothers and sister, in order to maintain and establish the new country. (Anderson, "Phillis Wheatley's Dido" 58)

This reading of Wheatley's poem provides a glimpse into what Russwurm might have assumed about his child readers and their liminal positions in society. Through Wheatley's epic hymn, subliminal messages of freedom and justice emerge - tying indirect references to Aeneas's new nation. Upon the founding of Rome, Aeneas wanted Romans to expand their minds. Within the poem, Wheatley also uses a similar idea:

My son, my heav'nly fair!

Descened to earth, there place thy throne;

To succor man's afflicted son

Each human heart inspire:

To act in bounties unconfin'd

Enlarge the close contracted mind,

And fill it with thy fire. (Wheatley 95)

Using these lines, Russwurm and Cornish ask their child readers to consider their power in helping to form a new, progressive nation of people. Like Wheatley's "prince of heav'nly birth" black children's instruction asks them to create an America that has to contend with educated black youth. Their education allows them to enlighten this new nation and "Enlarge close contracted minds" and inspire human hearts. As Jacqueline Bacon suggests, the 1820s saw 
changes within the African American community, where communal efforts among freed blacks were more possible as African Americans sought to enhance their intellectual and civic capabilities (Bacon, The Humblest 40-42). Freedom's Journal with the help of Wheatley's reputation, sought to enhance the literary capabilities of blacks and thus help form a new nation of progressive individuals who sought liberty of the mind and body. Given that Russwurm was an avid proponent of the colonization movement for blacks in Liberia, Wheatley's poem might have provided him the language to articulate this newly-founded nation of educated black people.

\section{The Civil War Context and Wheatley's Circulation}

In 1863, William Wells Brown published The Black Man and included Wheatley's “On the Death of a Young Lady," which targeted a youthful audience. Though Brown states his purpose is to ultimately show the collective intellectual capabilities of blacks, his selections direct our attention to didactic undertones that focus on youth development in a society heavily influenced by nationalistic rhetoric. More importantly, Paula Garrett and Hollis Robbins remind us that Brown often advocated on behalf of "disenfranchised insiders" which were made up the freed population, educated women, and fugitive slaves. ${ }^{17}$ What Garrett and Robbins neglect to include are the child readers who were also familiar with Brown's collection. In fact, black children often read for their families, especially for newly freed slaves. ${ }^{18}$

${ }^{17}$ See the introduction to The Works of William Wells Brown: Using His 'strong, Manly Voice" vxii-xviii.

${ }^{18}$ See Karen Chandler's "Ye Are Builders" in Who Writes for Black Children? and Beverly Lyon Clark's Kiddie Lit: The Cultural Construction of Children's Literature in America 101. 
Considering Brown's editorial choices as accessible to children expands our understanding of The Black Man (1863) because they explain the values that editors wanted to instill in black children in the latter half of the nineteenth century. Brown includes Wheatley's "On the Death of a Young Lady of Five Years of Age," to expose black children to the philosophical, eloquent, and sublime responses to nature. ${ }^{19}$ This poem, which was not typically circulated in newspapers of the time, particularly places the child readers in the perspective of both adult and child. Within the poem, the narrator explains the transcendence of the young girl: “Th' enraptur'd innocent has wing'd her flight." In the new realm, the young female child, "find[s] unknown beautitude above" and "feels the iron hand of pain no more." The image of the iron hand makes another appearance and, in this context, juxtaposes entrapment and freedom. However, death transcends earthly pain and sorrow and instills a new identity that is similar to a death of fettered societal chains. Young readers who were caught between two worlds - one where they inherited social stigmatization as their parents, and one where they were much more likely to obtain somewhat of an education - could identify with the child/parent perspectives presented in Wheatley's poem. Aware of the stigma and prejudices that he and others face, Brown's purpose in his collection was to “vindicate[e] the Negro's characters and show that he is endowed with those intellectual and amiable qualities which adorn and dignify human nature" (Brown, The Black Man 6). Brown seizes the opportunity to counter the nation's reactions to

${ }^{19}$ Brown's later version of The Black Man (1863) entitled, The Rising Son: or, The Antecedents and Advancement of the Colored Race (1874) explains his rationale for her inclusion: “... her verses are full of philosophy, beauty, and sublimity. It cost her no effort to round a period handsomely or polish a sentence until it became transparent with splendor" (425). 
nationalistic rhetoric by employing Wheatley's poem in his collection. Given that Brown eschewed the more "heroic resistor" stance that Frederick Douglass employed in his writing, ${ }^{20}$ Brown's work shows the tools with which black youth used to navigate disempowerment.

Imagining death as a tool for navigating disempowerment and placing it in the domestic space that Wheatley's poem situates for Brown allows him to teach youthful readers about "admirable black men [and women] who pit themselves physically and morally against ruthless slaveowners in an effort to attain human dignity" (Garrett and Robbins xix). Reminiscent of Brown's 1847 lecture to the Massachusetts Anti-Slavery Society in which he criticized America for its self-conceptualization as the "Cradle of Liberty," Brown's reuse of domestic spaces in Wheatley's poem revises and extends his ideas on death's sublime power. ${ }^{21}$ With Wheatley's poem, he reimagines what America's idea of freedom has been for black citizens and how they found human dignity even in the most abject conditions.

One way of imparting this important lesson to black children was to mine the domestic references that Wheatley's poems expressed. Since Brown often used domestic references and aimed at a "concept of liberty that could be claimed by all those who were not yet full citizens," (Garrett and Robins xxiv) his intentions for instructing children can also be seen. Children, who were familiar with domestic spaces and objects such as nurseries and cradles, understood that usually the parents look down upon the child in its cradle. However, Wheatley's poem inverses

${ }^{20}$ See the introduction to The Works of William Wells Brown: Using His 'strong, Manly Voice,", xix.

${ }^{21}$ Ibid 91. In using a domestic point of reference, Brown explains that "If it [America] is the 'cradle of liberty,' they have rocked the child to death." 
the parent/child relationship by flipping the point of view. When the child dies and is at her "heav'nly home," it is she who "Looks down, and smiling beckons you [the parent] to come." This inverted view expresses the ways that it honors the death of a child; the child is positioned as the one who guides the parents. Through this viewpoint, black children could interpret their roles as well as those who've come before them as honorable. Even after they have passed, the legacy of their teachings still remains. In keeping with this inverted view, Wheatley reduces the parent's cries and groans to that of a baby's, while elevating the speech of the child to mimic clear language. Metaphorically, black children could view language acquisition as a godly act, empowering them to transcend the "iron hand" of entrapment and slavery. This metaphor could even extend to their duties at home where they were in the position to read to their parents who may have been newly freed slaves. This empowerment of speaking a privileged languagenamely the language of the oppressors' - could guide them from the "iron hand." The angel's role in the poem also attests to the inverted relationship. While the parent "moans," the angel soothes their tears and cries as if it coddles the parent. Simultaneously, while the angel soothes the parent's cries, the child sings songs of praises in a "tuneful sound" while joining other angels in heaven. This melody is meant to soothe the parent in much the same way as a parent does their crying child. Near the end of the poem, the angel begs the parent to "Adore the God who gives and takes away...Y Yourselves, safe landed on the blissful shore,/Shall join your happy babe to part no more.” The ending lines help black children understand death's power and meaning beyond America-namely that death opens up levels of freedom and honor that one should not be afraid of. In the domestic spaces of Wheatley's poem, Brown is able to impart lessons of legacy, uplift, and death as empowerment to black children. 
Following on the heels of Brown's collection of black writers and biographies, Lydia Maria Child dedicates The Freedmen's Book (1865) to freed people and renders from Wheatley's poem a lesson of creativity. She asks that "those of you who can read will read it aloud to others" (5). Her intentions were to give the book to the Freedmen's Aid Association for schools for black freed people, however, according to Robert E. Butchart, her book was only available to some black schools in New Berne, North Carolina (126). Youthful readers immediately identified with Wheatley's life because of the way Child renders it in a story-telling mode; Child strategically places her story of Wheatley's life before readers encountered the elevated lines of “Thoughts on the Works of Providence." Child begins by explaining how John Wheatley bought Wheatley, all the while deemphasizing slavery. She explains, "She [Mrs. Wheatley] took her home in her chaise, put her in a bath, and dressed her in clean clothes" (86). In this light, John and Susanna Wheatley appear as benevolent overseers who simply rescue her from her condition, instead of as participants in a system that enslaves blacks. Butchart praises Child's book for its non-conservative depiction of blacks by comparing it to the African Civilization Society's school books; Child cannot be exempt from criticism of conservative depictions of blacks because she sentimentalizes Wheatley into a "poor little orphan" instead of a child-slave. Nevertheless, Child's insertion of this particular poem is important for what it does for black youth.

On the first page of Wheatley's poem, Child inserts, "Written at sixteen years of age." Emphasizing Wheatley's age hints at the type of readership that consumed her book. The poem follows a coming-of-age "sun" where the dependent "sun slumbers in the ocean's arms," then grows to "Ador[ing] the God that whirls surrounding spheres, / Which first ordain'd that mighty Sol should reign." Within these lines, the sun reigns over the land, going from a dependent state 
to independent. Consequently, the sun also guides the narrator's soul, ushering in the imagination's life cycle and proclivity towards creation. Child astutely draws readers' attention to the sun to emphasize its power. She writes as a note, "Sol is the word for sun in Latin, the language spoken by the ancient Romans" (94). She then points out that "Phoebus" also means sun in the Greek language. Using the sun as a metaphor for creativity, Child's attempt at instilling creative energies into the newly freed population serves as another form of early uplift in classical education.

\section{Decline and Resurgence in Wheatley's Circulation During and After Reconstruction}

Wheatley fades from the literary circulation scene during the Reconstruction era as violence against black education coupled with a burgeoning concern for an established American poetry canon entered the public arena. Postbellum America no longer needed editors of anthologies and newspapers to "purify" American verse-a new push toward American poets who defied their culture's dominant value was en vogue (Golding 294). Neglecting the stoic, religious. and moral poetry of the eighteenth century, one editor wrote in 1878 , "hymns and 'religious' poems... have been purposely excluded as out of place in such a collection as [Poetry of America]" (Linton $\mathrm{x}$ ). However, during the antebellum period, editors favored poetry that offered a politicized and moralized position on American verse. For instance, James N. Green reiterates that publishers of the early republic were not in bookmaking simply for the money. They saw themselves as "virtuous artisans doing well by doing good" (79). Going along with the ideal of republican virtue, publishers manufactured both a philanthropic and moral obligation in their book-making and dissemination processes from the 1820s on (Green 79). Nevertheless, the new turn toward poetry that defied normative cultural tastes spelled trouble for Wheatley, who was often marketed for her poems on religious and moral subjects. Gone were the days of 
Wheatley's galvanizing celebrity now that editors of books and anthologies sought to establish an American canon of poetry that featured William Cullen Bryant, Ralph Waldo Emerson, John Greenleaf Whittier, Henry Wadsworth Longfellow, Russell Lowell, and Oliver Wendell Holmes (Golding 292). The status of these poets were not often challenged because of the tight-knit literary community in Boston and New York that generally agreed with an established American poetry canon (Golding 292). Additionally, the onslaught of violence against newly freed people learning and the worsening racial relations in the country continued to prohibit black writers from publishing in major white-edited publications. ${ }^{22}$

Despite the silence from editors and publishers regarding Wheatley's poetry, her poem, “A Hymn to the Evening” resurfaced again in 1920, following a bibliography published in 1915 by Charles F. Heartman. Wheatley's poem resurfaces in a black children's publication for the purposes of educating black youth about "the history and character of its own people..."(Pritchard and Ovington x). Myron Thomas Pritchard and Mary White Ovington's The Upward Path (1920), a reader for black children, follows in Arthur Donaldson's path 107 years later. Ovington, an avid white supporter of black advancement and among one of the founders of the NAACP (Horne and Young 155), and Pritchard a writer, educator, and children's author, were well suited for editing a collection of works primarily geared for black children. ${ }^{23}$ Working

\footnotetext{
${ }^{22}$ For more information on African Americans in schools after emancipation, see Ronald E. Butchart's Schooling the Freed People: Teaching, Learning, and the Struggle for Black Freedom, 1861-1876.

${ }^{23}$ W.E.B. Du Bois praised Ovington as a children's author, and thought her novels, Hazel and Zeke were well suited for black youth. See The Crisis, January 1914.
} 
within similar constraints as Donaldson in the early nineteenth century, Pritchard and Ovington faced debilitating laws that prohibited black children from learning. Restricted by segregation and Jim Crow in the early twentieth century, black children were stunted and often looked down upon as inferior due to the social stigmas and political obstructions that hindered their growth. Aware of the Jim Crow era laws which further restricted black children from necessary resources to enhance their learning, Pritchard and Ovington repurpose this particular poem to teach black children to take pride in their history. Robert R. Moton, the principal of Tuskegee Institute, relates in the introduction: “... the publishers have brought together a number of selections from the best literary works of Negro authors through which these young people may learn more of the character and accomplishments of the worthy members of their race" (x). Regaining celebrity status, Wheatley's poem appears among notable black writers of the latter nineteenth and early twentieth century with the exception of Benjamin Banneker. Here, Wheatley's singular poem, represented among "the best literary works of Negro authors" assumes the same recognition as it did in the early nineteenth century amongst abolitionists who circulated it to represent the young poet's literary prowess and to argue against slavery. ${ }^{24} \mathrm{~A}$ marked difference in the way it teaches "a valuable lesson" complicates the way it is repurposed in the twentieth century (Horne and Young xi). Editors of this school book show the relevancy of Wheatley's moral verse by taking the lessons it imposes and teaching children in the wake of Jim Crow and segregation in the

${ }^{24}$ See T. Clarkson's Essay on the Slavery and Commerce of the Human Species (1816), the abolitionist periodical, Genius of Universal Emancipation (August 1821, Volume I, Issue 2), the Christian Reflector (1843), the Christian Secretary (1843), and African Repository and Colonial Journal (August 1843) which featured "A Hymn to the Evening." 
twentieth century. Moral verse communicated the tenets that schools for black youth promotedindustry, historical knowledge, and morality..$^{25}$

It is curious as to why these editors chose Wheatley to teach a valuable lesson to black youth given her neglected status during the postbellum years. Quite possibly, Wheatley's status as a reputable poet as purported by George Duyckinck in his 1856 and 1866 Cyclopedia of American Literature set the stage for Wheatley's return to being seriously considered as an American poet. Within Evert Duyckinck's later editions, a biographical sketch and frontispiece accompanied Wheatley’s poems (Young 120). George Duyckinck “analyzes Wheatley’s place and her 'evidence' in the literary traditions" (121). Young continues, "For the first time, Wheatley is viewed as an American Poet..." (121). Another reason these editors may have included Wheatley may have been because of the growing power of the Harlem Renaissance movement that brought about an explosion of black artistic and social development along with pride in black culture, music, and performance. Black people felt that their concerns and voices were mainstream and that through their art and culture, they could claim authority to represent themselves. The affectious pride of the movement may have facilitated a pride in Wheatley's "An Hymn to the Evening" given her status as a great poet of her time as well as the moral message behind nature's new beginning. For these editors, Wheatley's poem reveals a desire to seek out truth in nature and to begin anew similar to the way that spring brings in the first stanza. The "blooming spring" softly "purl[s] the streams" and "renew[s]" the birds' notes. Coupling

\footnotetext{
${ }^{25}$ Most selections from this publication indicate a strong emphasis on morality and religious upbringing. Additionally, thriftiness and self-reliance are other themes that appear within the selected texts.
} 
nature and the Harlem Renaissance together could teach black youth the importance of new beginnings, history, and opportunity.

By emphasizing morality, Pritchard and Ovington's goals are similar to Donaldson's in that these editors share a consensus that black children could neither advance in the ways that white children could socially, but they could remain engaged civilians in America without upsetting the status quo. Robert R. Moton, Principal of Tuskegee Institute, suggests that many schools follow a path that teaches black youth "a valuable lesson" and "a direct appeal to the best impulses of the human heart" (xi). The Tuskegee Institute was formed by Booker T. Washington to teach black youth how to be a service to their communities while not protesting the racial segregation laws in the late nineteenth and early twentieth centuries. The lesson that many of the selections in this publication teach, including chapter three from Washington's "Up From Slavery," is that thrift, self-reliance, and hard work can ensure one's success in the changing race relations of the twentieth century. Wheatley's verse not only praises the majesties of God's creations, it offers solace to those who "wake more heaven'ly, more refin'd," so that their labors shall be "More pure, more guarded from the snares of sin" (Wheatley 95). The message within these lines draw youth to obedience to avoid the "snares of sin" so that they can reap the fruits of their labors. For some, Wheatley provided a moral compass for tackling the racist snares that often drew them to temptations and provided "placid slumbers" to "soothe [their] weary mind[s] (95). As long as youth followed the tenets of appreciation of God's creations, each day promised protection from sin. This message teaches children how to be industrious without upsetting the status quo. Additionally, both editors remind students that the past is something to remember, but to continue to reach forward. The title of their publication, Upward Path, foretells the trajectory that they and other educators in the early twentieth century sought for black children. Despite 
Jim Crow, Upward Path suggests a forward motion and hints at the expectation that educators had for black youth.

Another publication that featured "An Hymn to the Morning," "An Hymn to the Evening," and "To the Right Honorable William, Earl of Dartmouth" intended for black youth was Otelia Cromwell's, Lorenzo D. Turner's, and Eva B. Dykes' Readings from Negro Authors for Schools and Colleges (1931). These editors explain their aims:

The purpose of this volume is not to present another anthology of Negro literature but to offer for class room study or supplementary readings a selection of types of writings by Negro authors. Inasmuch as the standards of literary forms are based upon universal principles, Negro literature demands no unique method of approach, no special interpretation of the rules of craftsmanship. (2)

This early publication discourages youthful readers from viewing African American poetry as possessing unique qualities that call for special readings or "unique method[s] of approach." This idea (which is considered unpopular today) teaches black children that learning black verse "based upon universal principals" was essential to their education. Oddly enough, Cromwell's, Turner's and Dykes' edited collection dismisses claims about unique perspectives that the Harlem Renaissance espoused, while upholding a constructed universal canon of African American literature. Within this context, children are taught to value Wheatley's poems for their attention to traditional verse and style rather than for her position as the first African American poetess.

Wheatley's poems arbitrarily categorized under "Poems inspired by Nature" and "Portraits in Verse" in Readings from Negro Authors, attest to the key features of American poetry according to these editors. Within their introduction, they relate that thought, emotion, 
imagination, and rhythmic language form "essential qualities of the art [of poetry]" (3). Taking cues from Romantic English poets Wordsworth and Shelley, the didactic and gnomic nature of Matthew Arnold's poetry, Poe's The Poetic Principle, and Amy Lowell's Tendencies in Modern American Poetry (1917), they envision how black poetry fits within these standards. Wheatley's hymns now categorized under "nature" establish her verse as the quintessential model for art. She is celebrated in this context by the way she "vivifies everyday experiences and beautifies the bare facts of life as [s] he awakens us to see what is about us" (313). This new rendering of Wheatley's poems to black children establishes her among other well-known black-American poets - Alice Dunbar-Nelson, Paul Laurence Dunbar, Angelina Grimké, Countée Cullen, etc.and among well-known English and white-American poets. Additionally, understanding "Dartmouth" as a poem that exemplifies imagery teaches young children how to imitate her style. Freedom in this poem takes on many meanings; Wheatley describes it as a goddess, America, and even from her own point of view. Given the editors' goal in teaching children to read more and to learn how to critique art, Wheatley's verse teaches children how to envision abstract concepts in concrete terms that provide new meaning to them. Wheatley's poetry exists within this publication to teach black children the refined tastes of lyrical English poets, who were hailed as the quintessential poets of the century (and even today). Claiming that early poets already possessed the universal standards of poetic art and that their poems should not be read differently places them on equal footing as, for example, Wordsworth and Shelley.

On the opposing side of viewing Wheatley's verse as emblematic of poetic art for youth was Benjamin Brawley, a black editor, historian, and Harvard graduate of the early twentieth century. Brawley included several of Wheatley's poems in his collection Early Negro American writers: selections with biographical and critical introductions (1935). He is in fact one, if not 
the only black editor of his time who draws attention to her youthful status and includes extensive selections of Wheatley's oeuvre: "To the University of Cambridge," "On the Death of Rev. Mr. George Whitefield,” “To the Right Honorable William, Earl of Dartmouth,” “An Hymn to the Morning," “An Hymn to the Evening," "On Imagination," "Niobe in Distress for her Children Slain by Apollo,” “To S.M. A Young African Painter,” “To His Excellency General Washington," and “Liberty and Peace.” ${ }^{26}$ However, his aims differ from Cromwell's, Turner's and Dykes' and he expresses them in his preface: "We at once face the fact that, judged by artistic standards, much of this early writing is weak." He continues, "It is hoped, accordingly, that the book may be of service to the student of the history of the Negro as well as to one concerned with literary values only (Brawley, Early Negro American v). Earlier anthologies of the 1920 s, especially that of Alain Locke, ushered in ways of depicting black poets according to how much they represent race consciousness. Similarly, Brawley expresses his dismay at most of her poems that "contain [sic] not a single reference to race" (Brawley, Early Negro American 36). Without this factor, black poems could not fit within the standards of great art. Thus, Wheatley's poems became only valuable for what they taught children about literary value in her time. Though some of her poems spoke to the poetic values of the twentieth century-

${ }^{26}$ In Wheatley's biography, Brawley mentions her age at different levels of her composition career. He says that she was able to write the heroic couplet at sixteen or eighteen (34), and even draws attention to an advertisement that printed, "A Poem, by Phillis, a Negro Girl” whenever Wheatley's "On the Death of the Reverend George Whitefield" was published (32). At one point, he even calls "On being Brought from Africa to America" a juvenile poem (35). 
objectivity, vivid imagery, etc. - she stayed popular in the mid-twentieth century simply for her status as the first black woman poet of the African American literary tradition.

To understand Brawley's inclusions of Wheatley's poems in his text for students, it is helpful to peer into his stance on black poetry. In 1917, Brawley asserted in his article in The Journal of Negro History:

...the work of those in question (George Moses Horton, Frances E.W. Harper, and Albery A. Whitman) almost never exhibits imagination expressed in intense, condensed, vivid, and suggestive phrase... When we further secure such things [refined taste] as these the race may indeed possess not only a Horton, a Harper, or a Whitman, but a Tennyson, a Keats, and even a Shakespeare. (Journal of Negro History 391-392)

Brawley further deduces that early black poets' works are "subjective and romantic rather than objective and classic" (Brawley, Journal of Negro History 391). Viewing Tennyson, Keats, and Shakespeare as objective and classic while viewing early black poets as subjective and romantic renders future readings of these poets in a similar light. Brawley situates the standards of poetic art among early white lyrical poets; his expectations along with those of the editors of Readings from Negro Authors are that black poets should imitate white poets to some degree to achieve a refinement in their character. Wheatley's attention to many classical elements within her text (the muses and Aurora, to name a couple) and her reputation as an objective observer won Brawley's attention, yet her lack of race consciousness helped the editors of Readings from Negro Authors 
rationalize her inclusion in their collection of universal verse. ${ }^{27}$ Brawley also later concludes in his article that blacks' technique and lack of mastering the fundamentals of English grammar has hindered them from reaching "the ultimate standards of art" (Brawley, Journal of Negro History 391). Thus, Wheatley's evolving status as a poet of substance to a poet merely valuable for her historical significance created scholarship that later depicted her role as miniscule in a developing African American literary canon.

\section{Wheatley's Circulation in the Present}

Today, Wheatley's legacy as a children's author is forgotten in public schools. The West Virginia English Language and Arts Common Core curriculum's standard text, Collections (2017) features a range of prose, poetry, and miscellaneous documents that teaches $11^{\text {th }}$ and $12^{\text {th }}$ graders to read literature and informational texts (non-fiction), write, speak, listen, and understand grammar (xxiii). In Collections, which highlights major literary works that helped shape American values and beliefs, Wheatley receives minimal attention, even though her poems previously taught black children uplift. The inclusion of "To the Right Honourable William" and "On Being Brought" side by side in Collections, reinstates the protest and resistance/nonresistance framework. The editors acknowledge this framework by asking students to discuss Wheatley's “overall tone toward America" in "To the Right Honourable William," and to focus on "Wheatley's view of life in the Colonies" by reading the "final couplet of 'On Being Brought

\footnotetext{
${ }^{27}$ Alaine Locke depicted Wheatley not worthy of study outside of her historical significance because she did not attend to race in her poetry. See his influential The New Negro: Voices of the Harlem Renaissance. Also, Brawley later claimed that Wheatley was objective in her poetry. See Early Black American Writers 34.
} 
from Africa to America'" (156-157). The final couplet reads, "Remember, Christians, Negroes, black as Cain,/ May be refin'd, and join th' angelic train" (154). Narrowing students focus to Wheatley's reactionary discourse severely hinders students from thinking about her beyond power dynamics. In Common Core, Wheatley is valued for how she demands better leadership for Americans and for how America redeemed her.

One high school teacher, Toni Poling, who teaches English at Fairmont High School in West Virginia further explains the limited representations of Wheatley in the Common Core classroom. When talking about the placement of "To the Honourable William, Earl of Dartmouth" in Collections, Poling states, "I don't teach that one; I don't think it's a fantastic representation and I don't think it resonates well with the students" (Poling). Poling further suggests that teaching "On Being Brought from Africa to America" is a better way to teach Wheatley because of its first-hand account of the slave experience in America. She uses this particular poem as part of her historical introduction when teaching about slavery in the U.S. When asked if she used or encountered other poems by Wheatley, she explained that she did not. In fact, these were the only two poems she has encountered in her own schooling as well as during her career as a teacher. She laments that Common Core does not focus on historical contexts and explains that the lack of doing so contrasts to her beliefs on reading literature. As evidenced in Poling's comments, Wheatley's legacy of teaching children moral uplift is forgotten in lieu of teaching her reactions to American leaders. One silver lining, however, is that Poling's teaching method stresses the historical context over the literary context to help students better grasp what they analyze. Understanding historical contexts can lead to productive lines of inquiry, such as understanding that African American literature is not only limited to the adults who resisted. 
Wheatley appeared in many publications intended for black children. The many re-uses of her work become apparent when deeply excavating her circulation history. Children's magazines and schoolbooks recreate spaces for black youth to imagine different modes of freedom. Within the popular poems from Wheatley, black youth become acquainted with the fantasy of her biography as well as what it brought to children of newly freed black families. In addition to how her poetry served black children, abolitionists and later editors of collections sought to reimagine the body using Wheatley's poems on nature. Once abolitionists realized that black writers brought a differing perspective to western writing, many sought to capitalize on this perspective. Today, Wheatley's works are celebrated for their historical legacy and subtle diverges from western writing. Given that past editors used Wheatley's poetry to spur black children's activism, it is important to recognize how her legacy could teach future generations of children how to imagine liberalism in times where their freedoms are constantly challenged. Though uplift failed in many respects because of its emphasis on class distinctions, it played a role in developing socially conscious black children. 
George M. Horton: The Children's Poet

Scholars can glean evidence that editors continued to recycle poetry for its messages of childhood from obscure poets' reception histories. George Moses Horton does not make many appearances in the African-American literature canon, yet, he was a local celebrity. The few scholars who analyze Horton's poetry focus on his Civil War poems and his speeches. Long represented in literary criticism as one of the forerunners of protest poetry, George Moses Horton stands as the first published African American poet in the south. ${ }^{28}$ Recently, Faith Barrett's work on the ways Horton appropriated western literary traditions such as Romanticism yields new insight into Horton's agency. Barrett explains that Horton used a patchwork of western literary traditions to resist and elude white authority. Imitation signaled the appearance of mastery, yet not in a way that made Horton's work original. Barrett argues that originality attracted dangerous threatening attention from jealous whites. Other scholars explain the rhetorical gymnastics that Horton performed to appeal to his white audiences for membership in a national consciousness (Williams). Their work brings to light the performative aspects of Horton's poetry and I extend this framework by offering it in a different context—children's literature. By understanding Horton's reception, we also understand how editors used Horton's poetics in various contexts for children. His poetry appeared in children's literature because it performed an appreciation of the stylistic themes of romantic literature, while offering subtle critiques of its environment. His speeches reveal how he actualized diffidence and his poems reveal how he performed the morality, friendship, and citizenship that made them popular among abolitionists and black editors. Early twentieth-century critics forgot about this strand of his legacy as they searched for

${ }^{28}$ See Sandra O’ Neale's “Roots of Our Literary Culture: Horton and Biblical Protest” (1981). 
a poet who represented the experiences of blacks in a new aesthetic. As time progressed, Horton was only remembered for his local celebrity as the first published southern black poet.

Born in Chatham County, North Carolina, many locals including students of University of North Carolina called him the black bard of UNC. To date, Horton published three poetry collections of varying quality. For the first collection, The Hope of Liberty (1829), Horton had an amanuensis to record his verses, though it is believed that he wrote the latter collections. Editors as early as the nineteenth century mostly repurposed poems from his first collection, though some draw from his later collections, The Poetical Works (1845) and Naked Genius (1865). Horton's reception history reveals a few narratives about the life of his work: 1) Horton valued education and performed his role as an orator in front of audiences; 2) white editors found creative ways to teach white children and students activism and societal participation later in the nineteenth century using Horton's poems; and 3) black editors encouraged black students to navigate their environments by using Horton's nature poems. All three narratives inform how we should reconceive Horton's place in the African American literature canon as a children's poet. As I will show, Horton's poems helped editors teach black and white children how to enact republican virtues in a fractured nation. After emancipation and a more uniformed nation, Horton's poems fell into obscurity until the early twentieth century. It is during one of the most difficult times in African American cultural history that Horton's poems resurfaced to help black children navigate their environments. After Jim Crow, Horton's importance in children's literature faded, yet some twenty-first century multiculturalist accounts use Horton's poetry to teach children about his legacy. 


\section{Horton's Performative Qualities}

Horton's speech, “Address to Collegiates of the University of N.C.: The Stream of Liberty and Science" delivered at UNC in 1859 provides a contextual framework for understanding how he imbued his poetry with similar performative functions. ${ }^{29}$ The sixty-twoyear old enslaved George Moses Horton delivered one of many speeches at Gerrard Hall. In the speech, Horton nodded to the importance of educating and learning and included his remonstration of students who "laugh to his [Horton's] ignorance" (Horton 3). Horton recognized that his more privileged counterparts did not fully use the advantages that they were born with. He saw this as a lost opportunity for improving the world (Horton 3). The incoherent speech used biting criticisms of students who wasted their talents; however, it offered advice and learning experiences for students' advancement into "professional fields" (3). Earlier developments of Horton's philosophy came from his poetry circulated to children. "The Slave's Complaint," which speaks about similar concerns with chastisement from whites, provided Horton words for articulating how students should not laugh at his ignorance. His poetry performs the same diffidence and delivers a subtle message about acceptance without becoming a threat.

${ }^{29}$ The exact dates of Horton's speech are speculative, but Joan R. Sherman states that Horton delivered his speech sometime in the year of 1859 in Gerrard Hall to the Chapel Hill campus. See Sherman's The Black Bard of North Carolina 23. Gerrard Hall, according to Documenting the American South, hosted invited guests to speak, like U.S. Presidents Polk and Buchanan. See Constance Chia's introduction to Horton's Speech on Documenting the American South's website. 
Not only did Horton situate educational motifs throughout the speech, Horton shrouded his rhetorical diffidence with agricultural allusions. Horton asked that the freshmen pledge to pity and respect his position, being such that the "pain" of his intellectual work was "effused from a plough broken receptacle..." (3). As an enslaved man, Horton, did "undesirable" work as a “cow-boy" and often ploughed in fields (Poetical Works iv and xiv). Offsetting students' laughter with his appeals to a common agricultural tool meant that Horton could relate enough to his southern, white male audience to teach them about morality and recklessness. This labor, both metaphorical and literal, granted Horton an identity that matched the respect he hoped for as an orator. His agricultural upbringing equated to the "professional fields" he envisioned for the freshmen class and possibly for himself. As Horton related in his second poetry collection, The Poetical Works (1845), he sought the "popular distinction" of one who uses "discourse" and shows "a spark of genius" (Poetical Works xiv). However, he soon learned that UNC students engaged with his speeches simply to mock him, and he soon regarded his "enthusiastic pride" as an orator as a "vain egotism" (Poetical Works xiv). Nevertheless, by the time of his speech to the freshmen class, Horton had already gained a reputation as a genius poet, especially by UNC's Chapel Hill Gazette. ${ }^{30}$ Horton's speech along with his poem, "On the Pleasures of College Life" offer glimpses into the performative qualities of his work. Because Horton infused a romantic literary style with non-violent allusions of protest, nineteenth-century editors recycled his poetry

${ }^{30}$ See the Chapel Hill Gazette's May 9, 1857 issue which provides the following description of Horton's poem "What is Time"....George Moses Horton, an extraordinary colored poetical genius, the property of Hall Horton Esq. of Chatham County-This man is the author of a book of poems, entitled Horton's Poems, which is well known in this part of North Carolina" (2) . 
to educate children and students about morality, nature, and friendship. Twentieth century editors appreciated Horton's agricultural allusions and appropriated them in schoolroom texts for black students. Twenty-first century editors appreciated his protest poetry and used it to teach children about black legacies of resistance. The diversity of his poetry's contexts speaks to the performative qualities it used to navigate the children's market.

Known to his contemporaries as the Black Bard of the University of North Carolina at Chapel Hill (UNC), Horton remarkably published two volumes of poetry during his enslavement and his last work of poetry after he was freed in 1865 . Because Horton could not write until 1832, his first poetry collection, Hope of Liberty (1829) was possibly transcribed by Caroline Hentz who was a writer and whose husband taught at the university (Sherman 10). The collection featured twenty-one poems covering an array of topics ranging from death, slavery, nature, love, and innocence. Hope of Liberty secured a regional reputation for Horton and "Liberty and Slavery," a protest poem from this collection, was the most circulated poem in abolitionist and black newspapers. Particularly, after Hentz sent "Liberty and Slavery" to her hometown newspaper, the Lancaster Gazette in 1828, editors from the Raleigh Register (1828), Freedom's Journal (1828), The Chapel Hill Gazette (1857), and The Emancipator (1857) began circulating it to promote Horton's emancipation.

While "Liberty and Slavery" provides insight into Horton's emancipation, scholars neglect how this poem influenced children's insights into emancipation. For instance, editors featured this and other poems in white children's magazines as a way to teach them about emancipation. Critics and scholars have positioned Horton in the literary canon as a protest poet solely on the ways he protests. They neglect how his protest poetry influenced children's literature, which editors used to teach friendship as a form of communal abolitionism. They have 
also neglected to account for abolitionist and post-war publications that found an appreciation for Horton's nature poetry. In these instances, we see Horton's identity transformed not only into a protest poet, but a children's poet.

In fact, Horton's reception history reveals a need to reorient conversations around the uses of early black poetry to extend the conversation of protest to child readers. Horton's reception as an orator lends insight into the ways black abolitionists and white women abolitionists used Horton to reshape juvenile abolitionism and education in the $1820 \mathrm{~s}$ and $1850 \mathrm{~s}$. Oftentimes, these editors lend sentimental visions of enslaved people that did not grant them the agency that most scholars look for. Therefore, modern discourse surrounding agency and protest lend one-sided understandings of Horton's poetry and cannot account for its complex usages. Horton's poetry was employed in the nineteenth and twentieth centuries as a way of shaping African Americans identities with the natural landscapes. This post-war re-envisioning of African American capabilities served many benefits to newly freed people and worked as a form of community building. It later influenced the ways twentieth-century editors imagined new identities for Jim-Crow era students. In the twenty-first century, these threads intertwine and create an image of as a protest poet for adults.

As early as 1845 , Horton envisioned himself as an orator in his poem, "On the Pleasures of College Life," found within his second collection, The Poetical Works. The poem's instructive tone directs the reader, or student in this case, to follow its directions, especially in the third stanza: "Now let us take a retrospective view/And whilst we pause, observe a branch or two" (108). Horton places romantic ideas of nature into the poem to perform his mastery of botany. The narrator emphasizes botany and geography as two important subjects that fill the narrator with romantic visions of pleasure. Often oscillating between romantic depictions of pastoral 
nature intermixed with ideas of college life, Horton develops his voice to speak about the natural world (109). Given Horton's tendency to explain life through natural metaphors, it isn't surprising, that he used a metaphor to explain theology as a tree: "Beneath whose boughs the silent classics sit" (109). The majority of his poem contained rich interdisciplinary subjects between the human and non-human. Horton shows a symphony of subjects meshing science, philosophy, nature, and theology into a 70-line, alternating rhythmic poem. His goal was to show his mastery over these subjects, to place himself in a position to be an orator. Though he hasn't received a formal education or "the liberal charms of college life," he speaks to his audience with the same conventions of his time. This role supports his recognition as an orator who helps students understand "Milton's theme," or "Pope upon the gales of epic song” (Horton 108). Like a performance, Horton is able to syncopate romantic ideations with lines of protest.

\section{Horton's Performative Romantic Poetry}

Horton's performance of romantic understandings of nature in his poetry inspire his speeches. Horton expressed his desire to deliver messages as early as 1859 during his 29-page Gerard Hall speech entitled, "Address to Collegiates of the University of N.C.: The Stream of Liberty and Science" to freshmen of UNC (1). ${ }^{31}$ Many times, Horton explains his desires to speak in his "The Stream of Liberty and Science":

${ }^{31}$ Horton states, "I appear before you, as a public orator. In the cause of liberty and science; but with a degree of diffidence lest I fail to accomplish a task which I feel it my duty to discharge...he [Horton] still is constrained from e[sic] impulse of illiterate genius to expose his jargon to the criticism of the world, it is obvious that we occupy an age of the world, which calls 
Your unworthy speaker is far from flattering himself with the vain idea of being endowed etent [sic] abilities to counsel a concourse on so lofty a [sic] where superior liberties afford them so many tionate [sic] advantages. Yet, while you laugh to his ignorance, he still is constrained from e [sic] impulse of illiterate genius to expose his jargon to the criticism of the world... (1) ${ }^{32}$

Horton speaks responsibly and uses diffidence in his speech. He speaks about his constraints, explaining how they work to his advantage. He proves that it is not only the privileged students who get to speak, but even an "illiterate genius" can "expose his jargon to the criticism of the world" (1). Horton did not receive serious appreciation; his role as an orator helped him imagine performative roles in his poetry. His performance speaks not only to the environments he navigated in his lifetime, but how it helped his poetry navigate the confines of print culture for African Americans. Horton's poetry, infused with his performative qualities as an orator, navigated print so well, that it was able to influence children audiences.

Even when Horton published his second volume of poetry, Poetical Works (1845) which exemplified his desire as an orator and observer of nature, scholars dismissed his interest. For

aloud for literary improvement from every quarter and the scientific culture of faculties rational... (1).

32 The document for Horton's “Address to Collegiates of the University of N.C.: The Stream of Liberty and Science" (1859) can be found at UNC's Library at Chapel Hill. Unfortunately, due to age, the text is torn in places and is the reason for missing words in the quote. The source text I used can be found on Documenting the American South's website, which features an image of the actual document from which I derived this quote. 
example, accounting for the reason behind the volume's appearance, Joan Sherman explains, “The Poetical Works contained no antislavery poems, in keeping with the new repressive atmosphere and publishing restrictions" (17). Horton desired to show his readers an appreciation for nature; however Sherman focuses on the harsh political and social environment in the early 1840s that she believes lead to Horton's non-slavery topics. ${ }^{33}$ This focus does not fully account for the complete story behind his lyrical poems on nature and friendship that children's newspapers circulated. This narrative neglects the complexity of Horton's Romantic performance poetry, and thus hides the possibilities of finding it in children's literature.

The "illiterate genius," the name either Horton or his transcriber used in the speech, goes so far as to suggest that his teaching could transgress spatial boundaries. Horton shows the farreaching geographical influences of his poetry. He explains:

it is obvious that we occupy an age of the world, which calls aloud for literary improvement from every quarter and the scientific culture of faculties rational, nay as well from the rustic swain in the lonely valley, as the epicure on luxuriant streams. (1)

Horton's reputation as the first black bard of North Carolina reached as far as New York and travelled to Massachusetts via newspaper (Sherman 11). Newspapers aided Horton in his desires to reach "the rustic swain in the lonely valley," "nations and color," and "the wandering novice, who could scarcely distinguish a letter from a figure" (1). Antebellum and post-war publications circulated his poems in contexts of abolitionism and the classroom. For instance, Freedom's Journal (1828), Eliza Follen's The Child's Friend (1843-1858), Lydia Maria Child's The

${ }^{33}$ See Joan Sherman's introduction to The Black Bard of North Carolina 16-17. 
Freedmen's Book (1865), and Newman Ivey White and Walter Clinton Jackson's 1924

anthology all use Horton's poetry to teach students of all ages about morality, citizenship, and friendship in varying degrees.

Michael Cohen's work provides a lens with which to focus Horton's circulation history. Poems in the nineteenth century, as Michael C. Cohen relates "occupied a complex position in the history of social life and sociality" (Cohen, Social Lives 9). In fact, poems were used as ballads, scrapbook pieces, and ephemera and often told stories about the social histories of cultural moments in the nineteenth century. For instance, poems gained significance when printed beside other news items, or they captured the sentiments of a movement and transplanted ideologies and voices from one region to another. According to Cohen, poems in the nineteenthcentury often "facilitated actions such as reading, writing, reciting, copying, inscribing, exchanging, or circulating" (Cohen, Social Lives 7). Whether Horton wanted it or not, his poetry was swept up into the anti-slavery movement and was marketed in the north as fodder for the movement's rhetoric. Not only was Horton's poetry used in the abolitionist movement, it was used in contexts of schooling children about friendship and morality. These contexts are often forgotten when scholars discuss the abolitionist movements. ${ }^{34}$

\footnotetext{
${ }^{34}$ I define friendship within the context of abolitionism where white abolitionist women articulated a mode of abolitionism for juvenile audiences that involved empathy for white children, morality, and forms of uplift for black children. The ways in which the concept was employed varies between each publication, but the foundational concepts of forming communal ties with disparate groups of people remains the common denominator throughout all the publications.
} 


\section{Horton's Life}

Before delving into Horton's circulation history, a brief accounting of his life helps formalize an understanding of Horton's position in the African American literary canon. Horton was born in 1797 in Northhampton County, N.C. as a slave to William Horton. He had seven sisters, and one brother. ${ }^{35}$ After a decade of labor as a cow-boy, he composed poetry in his mind while working in the fields and learned to read from "Wesley's old hymns" (Horton iv-viii). After hiring his time to sell "fruit to the college at Chapel Hill on the Sabbath," (Horton, Poetical Works xiii) Horton "composed" acrostics to young college men and charged them money in exchange for his poems. ${ }^{36}$ Of course, Horton had other students transcribe his work because he could not write at this time. His reputation as the black bard gained the attention of Caroline Lee Hentz, author of The Planter's Northern Bride (1854) and Lovell's Folly (1833) where she featured a character closely mirroring Horton (Stewart 87). She published two of Horton's poems in the Lancaster Gazette in 1828 and helped him transcribe his first book of poetry. Even though Hentz opposed abolitionism, she could keep Horton's poetry out of anti-slavery newspapers. From then on, Horton's poetry circulated in abolitionist, literary, and children's publications throughout the remainder of the nineteenth century. His second volume of Poetry, The Poetical

${ }^{35}$ For information on Horton's autobiography, see Life of George M. Horton, The Colored Bard of North Carolina, located in his second collection of poetry, The Poetical Works of George M. Horton (1845).

${ }^{36}$ Additionally, the college students gave Horton books such as Milton's Paradise Lost, parts of Homer's Illiad, Virgil's Aeneid, Byron, and a few grammar books such as Murray's English Grammar, and Johnson's Dictionary (Horton, Poetical Works xv-xvi). 
Works (1845) gained ninety-nine subscribers, including UNC students, the mayor of Chapel Hill, President Swain of the University, and others (Sherman 21). It was published by Dennis Heartt, a former New England editor of the Hillsborough Recorder (Sherman 21).

Finally, Horton's last volume, Naked Genius by George Moses Horton (1865) was published after Horton's travels with the $9^{\text {th }}$ Michigan Cavalry volunteers under Captain William H.S. Banks (Sherman 29). Horton, according to Banks, sought refuge under the cavalry in Raleigh after they occupied it during the Civil War. Whether or not Horton walked to Raleigh, which is thirty miles from Chapel Hill is uncertain; yet, it is true that Horton traveled with the cavalry for three months when he was sixty-eight years old. He composed ninety poems during his travels and included them in his last known published work. Beyond Horton's travels and his 1865 publication, Naked Genius, little is known about Horton after his emancipation. He was freed at nearly seventy years old during his travels with Colonel William Banks who sponsored his last published work; Faith Barrett suggests that evidence points to the likelihood that Horton traveled to Philadelphia after his emancipation in 1866 (Barrett, ““Naked Genius”” 79).

In spite of the mysteries shrouding Horton's life, scholars predominantly represent his life as a protest poet. I propose that we focus our attention to the ways his protest poetry extended beyond adult circles. Early black publications often for mixed audiences of children and adults circulated Horton's poems to bring light to a genius in bondage or to teach a form of moral uplift. Freedom's Journal (1827-1829) in New York published three of Horton's poems to raise awareness of Horton's condition and found purchasers to help free him. Despite the failure of their efforts, Horton's name was featured in prominent circles whose members fought against his enslavement. David Walker contributed to Horton's manumission fund according to the October 3, 1828 issue of Freedom's Journal. Despite their trying, Freedom's Journal could not 
raise money to manumit Horton and the newspaper ceased printing Horton's work. What their selections from his oeuvre suggest is a need to fill in the missing parts of his identity. White abolitionist women used Horton's biography and poems as an exemplar of friendship, black achievement, and morality. The performativity of Horton's poems ensured that his messages circulated for child audiences.

\section{Horton in Black-Authored Newspapers}

On August 29, 1828 during the early fervent decades of the abolitionist period, the very first newspaper for and by African Americans, Freedom's Journal published Horton's “On the Poetic Muse.” Creators John B. Russwurm and Samuel Cornish infused readings for black empowerment, especially for younger generations. Their mission to capitalize on the moral and intellectual uplift of black Americans rings throughout their publications and Horton's poem aids in that mission. Similar to Phillis Wheatley's position in the newspaper, Horton's poems encouraged literacy for black readers, especially children. With its simple metrical rhyming scheme and mostly simplistic word choice, young readers could access the rhythm and meaning behind the narrator's words. Within this poem, Horton infuses exaltations of writing and inspiration into his metrical verse. Beginning with a flourish, the speaker of "On the Poetic Muse" claims to soar "far far above this world" invoking an image of the poet as other worldly and physically unbound. The narrator had metaphorical "Aerial regions to explore,/ With this ambitious Muse" (89). Casting the poet in this light emphasizes the explorative nature of education and the opportunities it unlocks for those bound by ignorance. This line of thinking coincided with Russwurm and Cornish's mission. They felt it their duty to uplift the black community morally and intellectually. Russwurm mentions in the 1827 issue of his newspaper: 
It is our duty and privilege, by the faithful improvement of all the advantages which we possess, to convince a Religious and Republican nation, of the importance and policy of raising us in the scale of being. It becomes us, therefore, never to neglect any of the means of education within the reach of ourselves or children. (Russwurm)

Weaving Horton's poetry into their publication provided Russwurm and Cornish an opportunity to educate black readers about the performative nature that poetry and writing brought to the community. Performative liberalism, as discussed in the last chapter, allowed black children ways to uncover freedoms through poetry.

Later in the poem, Horton emphasized that the responsibility of the poet resembled the responsibilities of black citizenship in a community. That is - each citizen had a responsibility to enlighten and to create opportunities for future generations. For example, near the end of stanza three, the narrator relates that the muse aspires to remote scenes "as never yet exprest" suggesting that the poet must explore uncharted territory in order to kindle the "mystic fire" within the poet's breast (Horton 89). The preceding lines express that one is obligated to educate and enlighten oneself in order to bring about change to one's circumstances. This line of theorizing was a way for black citizens to enact their citizenship through print culture. According to Derrick Spires, circulation through spaces such as periodical literature and poetry became one among many ways black citizens practiced citizenship with each other (246). ${ }^{37}$ By circulating

\footnotetext{
${ }^{37}$ Spires relates that black community members developed citizenship practices around neighborliness, circulation, economics, critique, and revolution in pamphlets, conventions, sketches, periodical literature and poetry. See Practice of Citizenship (2019).
} 
Horton's poem, Russwurm and Cornish were able to articulate principles that aided in mutual respect and humanity for black readers. One of those principles, self-improvement, is seen throughout Horton's poem. By situating that principle in the hands of the poet, Russwurm created opportunities for black children to envision themselves as agents of change.

Horton's emphasis on the role of the poet reflected the growing importance of the poet's performative role in society, which helped editors such as Russwurm circulate his poetry for publication. Poetry was highly regarded during the period 1741-1850 (Kribbs vii). Michael Cohen, Faith Barrett, and Jayne Kribbs have demonstrated and explained how literary circles regarded poems as forms of what Paul Guillory terms cultural capital for the newly formed middle class of the nineteenth century. Access and use of the metrical and oftentimes genteel conventions of poetry allowed white and some freed peoples upward class mobility. ${ }^{38}$ Horton, well aware of the influence of the poet, used his verse to create empathy for the abused in his 1859 speech:

mankind that... are more fond of listening to what abuses recognized genius or a superiority of mental eminence particularly in one of low birth and rude raising than to expand the narrow circle in which he stands. (Horton, "Collegiates" 7)

Using himself as an example, he explained the importance of educating those with less opportunity so that more individuals like him could be called to "both private + public interest and duty" (9). He understood that he spoke to future statesmen, judges, physicians, and

${ }^{38}$ See Faith Barrett's discussion of poetry's use in “'Naked Genius': The Civil War Poems of George Moses Horton" in Timothy Sweet's Literary Cultures of the Civil War 80 and Cohen's The Social Lives of Poems in Nineteenth-Century America 7-10. 
theologians who one day worked toward the enhancement of humanity (9-10). Since Horton placed uplift ideology in his speeches, his poetry imbued similar messages. Editors of children's magazines used Horton's poetry to teach children, black and white, about the poet's legacy as well as standards of citizenship. With poetry's influence, black children could aspire to the standards of citizenship as their white counterparts and white children could learn to be responsible abolitionists in a society conflicted over the slavery question.

\section{White-Authored Collections}

Children's magazines and textbooks such as Eliza Follen's The Child's Friend and Family Magazine (1843-1858) and Lydia Maria Child's The Freedmen's Book (1865) featured Horton's poems on slavery and nature to teach children about morality, friendship, juvenile abolitionism, and romanticism. ${ }^{39}$ Children's magazines, especially Follen's, reflect the growing concern about religion and education in the nineteenth century. Under the tutelage of The American Sunday School Union (ASSU), Follen's magazine sought to teach basic literacy and morality to students who otherwise could not afford to attend school. Founded in America in 1824 and modeled after the Sunday school movement in England in 1780, the ASSU's objective

${ }^{39}$ Under different editors, The Child's Friend changed names throughout its 15 -year existence. From 1843-1845, it was titled Child's Friend: Designed for Families and Sunday Schools. From 1845-1851 under Follen's editorship, the magazine was entitled Child's Friend. From 18511855, the magazine was entitled Child's Friend and Youth's Magazine. Finally, from 1855-1858, under Anne Wales Abbot's editorship, the magazine was entitled Child's Friend and Family Magazine. See Kelly 125 and Pat Ptflieger's database entitled American Children's Periodicals, 1789-1872. 
was to disseminate moral and religious information to youthful readers. The organization's goal was to educate poor students as well as introduce moral and civic education (Kelly 122). The Union influenced public education mainly for its pioneering efforts in educating children who otherwise lacked the opportunities for schooling. The organization published The Child's Friend from October 1843 until February $1858 .^{40}$

Yet, while Follen sought to educate poor children, she used her magazine as a space to insert abolitionist views that sometimes clashed with the abolitionist movement in the early nineteenth century. Follen, a writer, editor, and abolitionist, asserted her distaste for the colonization movement that gained popularity in the early nineteenth century and placed a subtle critique of its philosophy into a very popular children's magazine. She created The Child's Friend "...to aid teachers and to be at the same time interesting and instructive to children" (111). Follen's Sunday school magazine featured moral content suited for child readers as well as fictional pieces that often told of child characters facing moral dilemmas. Natural science and geography lessons are dispersed throughout some issues. Even Nathaniel Hawthorne ironically contributed to the magazine by writing "A Good Man's Miracle" for the February 1844 issue. ${ }^{41}$

\footnotetext{
${ }^{40}$ For information regarding periodicals published by the American Sunday School Union, see Kelly's Children's Periodicals of the United States 122.

${ }^{41}$ In this account, Hawthorne creates an apocryphal account of Robert Raikes, who initiated the Sunday School movement in England in 1780. See Kelly's explanation in Children's Periodicals of the United States 122. What's ironic about his contribution to a woman-edited magazine is his remark about "the $\mathrm{d}-\mathrm{d}$ mob of scribbling women" to William Ticknor in January 1855. See
} 
Follen used Horton's biography and poem to teach lessons on juvenile abolitionism. Here, fourteen years after its publication Follen propelled Horton's work into Sunday school magazines, which aided his transition into a reputable, moralistic slave poet. Essentially, Horton became known in women-authored juvenile literature for his ideas on friendship, abolitionism, and protest. Horton's ideas on friendship help us understand the development of a juvenile abolitionist movement.

Follen articulated social awareness so that white children empathized with black children. In 1846, Follen published a tale called, "The Mother and Her Child," which depicted a white mother and her child magically transformed into dark-skinned slaves in the mother's dream. With this tale, Follen articulated the geographical awareness that white children should have when understanding how to be a friend. Many children may not be aware of another's suffering if they are not around it. Follen's use of the mother's revelation once she awakens brought the issue of enslavement close to home. She showed that the issue of slavery was not just for the enslaved; it was also the duty of all to ensure that human beings were free. The underlining details surrounding the tale reflect Follen's desire to articulate a mode of abolitionism friendship — that linked together disparate communities in order to reshape abolitionism for future generations. In other words, friendship helped humanize enslaved peoples and helped to bridge distances between the abolitionist and the enslaved. Follen enlisted white children in the fight for social justice for black children.

Letters of Hawthorne to William D. Ticknor, 1851-1864, edited by John Cotton Dana and Carteret Book Club (1910) for full context of quote. 
Situated among Follen's moralistic tales on September 1, 1845 was Horton's poem, “The Slave's Complaint," gathered from the first edition of The Hope of Liberty (1829). Follen attaches a brief biography of Horton, explaining his enslavement and from where she derived her entry. She explained the situation behind the purpose of Horton's first book of poetry, placing emphasis on his friends' efforts in securing his freedom:

It [The Hope of Liberty] further states that the little book was published for the purpose of collecting money enough from it to emancipate George upon the condition that he should go to Liberia, that these were the only terms upon which his friends made this effort in his behalf. (Follen, "The Slave” 255) Keen on instilling a lesson into each of her selections, Follen placed emphasis on "only" to critique the amount of effort Horton's “friends" gave to emancipating him. The tone in her depiction resonates into discontent as she criticizes Horton's supposed "friends." The concept of friendship for Follen intermingled with abolitionism and morality, as indicated throughout her magazine. ${ }^{42}$ Follen taught friendship on an elementary level, which indirectly enabled her to speak on empathy, sympathy, and morality to students in a domestic space. The Sunday school room provided a safe space for white women abolitionists to speak about their disdain of the colonization movement.

Because Horton's text performed the romantic idea of the sentimental slave, Follen was able to air her grievances on the nature of the colonization movement:

\footnotetext{
42 Throughout her issues, Follen included several entries explaining her and teachers' roles in being friends to children. See especially, "To Children" from the first issue in October 1, 1843 and a random axiom from the January 1, 1844 issue.
} 
In the preface to the second edition we learn that poor George was still a slave of the same master, that they did not succeed in getting money enough to purchase him and banish him to Liberia. (Follen, "The Slave" 225)

Within these lines, Follen links sentiment with friendship, which gives her the advantage of articulating a response to abolitionism that involved the work of friendship. She ascribed the adjective "poor" to Horton and used his first name as a way to create familiarity between the victim and the reader. Creating a sense of textual familiarity between the imagined "George" and the reader helped form a concept of friendship. Follen performed the act of friendship for her students by creating sympathy in her word usage. "Banish," also a powerful word meant to evoke sympathy, played a part in Follen's textual performance. Not only is George destitute, his friends wanted to "banish" him to a foreign country, causing readers to beg the question - why would anyone do this to a friend? This question and its accompanying implications secure enough reaction so that students understand the need to fight against slavery and colonization. As a result, The Child's Friend employed Horton's voice to influence generations of students to do more than Horton's friends did for him.

Follen placed the poem “The Slave's Complaint” after the brief biography, and it continued to aid her in appealing to her audience's sympathy. For instance, the narrator's contempt for slavery created a sentimental experience for readers. The narrator laments, “Am I sadly cast aside,/ On misfortune's rugged tide?/ Will the world my pains deride/ Forever?" (Follen, "The Slave" 257). Situating the biography before the poem helped Follen imagine the narrator as more of a victim than a protester in the spaces of her publication. Offering questions that only the reader can decide on created a unique opportunity for conversation between the reader and the narrator. Follen positioned her young readers to consider their stance on the 
narrator's affliction; they were left to contemplate the moral decisions of friendship and antislavery. The next stanza also employed a simple metaphor to ask readers, "Must I dwell in slavery's night, / And all pleasure take its flight, / Far beyond my feeble sight, / Forever?” (257). The night represented darkness for the enslaved people's futures. However, after holding the reader's attention with his questions, the narrator aked his reader, "Something still my heart surveys, / Groping through this dreary maze; / Is it Hope? - then burn and blaze/ Forever!” Not only was the narrator telling the reader about what he feels and sees, he strung the reader along by asking the reader if what he felt was "Hope." With this question came an influx of observations on morality - did the reader reveal his distrust in what the narrator felt, or should he assuage the narrator and answer positively. Having children consider these questions replicated the act of friendship; that is, children were tasked with considering another human being's feelings and humanity. Follen masterfully uses Horton's voice to anticipate an imagined exchange between the child and the enslaved narrator. Sentiment drove the questions; the action came from the child reader.

Before the reader answered, the narrator went on to ask for the reader's help: "Leave me not a wretch confined, / Altogether lame and blind--/ Unto gross despair consigned,/ Forever!" Follen likely chose this poem from Horton's collection simply because of this stanza; it begs the reader to help free the "wretch confined" (Follen, "The Slave" 79). The stanza also conflated physical and spiritual blindness to infer that slavery obstructed visions of the narrator's potential and future. Near the end, the narrator asked for an "eternal friend" to "Bid me from servitude ascend, / Forever!" The theme of a friend rung throughout Follen's publication as she grappled with answering the call and responding to the enslaved peoples' pleas for a friend. This theme within Horton's poem helped Follen articulate abolitionism for children. Defining what a friend 
was first, then showing through metrical poetry how one could empathize and help others in need forced intersections between listening to morality and practicing it. With the poem's easily memorized lines, Follen used it to serve the purposes of abolitionist juvenile literature-a genre that taught generations about the importance of their teachings. ${ }^{43}$ Near the end of Horton's biography, Follen iterated, "Children as well as grown people should think of these things" (Follen, "The Slave" 255). Their privilege along with another's suffering are the "things" of which Follen makes her child readers aware.

The success of Horton's reputation as a moral poet as evidenced in Follen's magazine also carried over into other publications in Ohio as early as 1858. The Ohio-originated newspaper, the Anti-Slavery Bugle (1845-1861) published “Reflections" from Horton's second collection, The Poetical Works (1845). The Anti-Slavery Bugle was the organ of the Ohio American Anti-Slavery Society, which later changed its name to the Western Anti-Slavery Society to broaden its membership and reach (Ohio Historical Connection). The publication ran for eighteen years and was the "only... voice of Garrisonian radicalism west of the Appalachians" (Ohio Historical Connection). It reached readers beyond Ohio and circulated in

${ }^{43}$ Memorization was the dominant mode of teaching for Follen and many others in the nineteenth century. However, Follen does indicate that memorization without discussion following the lesson does not yield successful results. See Follen's excerpt to teachers in her March 1, 1844 issue. The excerpt is entitled "Methods of Teaching." 
Iowa, Illinois, Wisconsin, and Indiana. It also served as the home of Sojourner Truth's 1851 speech delivered in Akron. ${ }^{44}$ The Bugle's mission was to:

Preach deliverance to the captive, and the opening of the prison door to them that are bound; to hasten in the day when "liberty shall be proclaimed throughout all the land, unto all inhabitants thereof. (1)

The editors, Benjamin S. Jones and J. Elizabeth Hitchcock also declared in their first issue that moral power was superior to political power. ${ }^{45}$ Their mandates were clear - the conduct and character of human beings were more important than the state's power. They saw their paper as a reforming agent meant to persuade readers against slavery. With their lofty goals and clear mission, the editors of the Bugle had their eyes set on anyone who contributed to their mission.

Horton's reputation as a slave and moral poet must have attracted one of the AntiSlavery's Bugle's editor, Marius R. Robinson's attention. Often known for his avid abolitionism and for teaching black children in Cincinnati, Ohio, Robinson curiously inserted Horton's

44 Truth's speech was not originally named “Ain’t I a Woman.” In fact, Truth was not familiar with southern slave dialect as she was raised in New York with a Dutch accent. See Podell's The Sojourner Truth Project for more information.

${ }^{45}$ Garrison assumed a pacifist approach to abolition, writing in The Liberator to persuade Americans morally about the immorality of slavery. He believed that politics compromised his position and avoided them. The Anti-Slavery Bugle, whose editorial policies Garrison helped to establish, follows moral suasion tactics as well by suggesting that "moral power" could "regenerat[e] public sentiment" whereas state powers "oversee and coerce" (1). See The AntiSlavery Bugle’s June 20, 1845 issue. 
"Reflections" from his least politically charged volumes, The Poetical Works. ${ }^{46}$ Within the autobiography of this volume, Horton explains his desire to be moral. It is no wonder, then, that Robinson chose a poem from this volume and placed it within the larger context of antislavery. Oftentimes, moral conduct and anti-slavery arguments went hand-in-hand. A poet who could articulate the short life-span of the nation and what it had (not) achieved could shine a light on the nation's misgivings and the importance of the Bugle. This sorrowful poem describes how fleeting human life and the nation's life is and the ways it is measured through smiles, affliction, and time. The narrator desires to be taught the proper way to write about life and history so that from a flight of inspiration, he can write about his "threescore years and ten" (4). At the time of publication, Horton was only forty-seven years old. The ending of Horton's poem referred to the age of the newly independent nation. Appeals to morality helped Horton achieve northern acclaim in the cause of abolition and his poetry served in spaces of protest - it helped articulate the work that the new nation still needed to do in order to recognize its greatness.

White editors such as Lydia Maria Child sparked interest in visions of black agency through the natural landscape. Child's collection, The Freedmen's Book tells a similar story

${ }^{46}$ Marius Racine Robinson was an Ohio-born abolitionist who volunteered his time to teach geography, grammar, arithmetic, natural philosophy, and Bible study to black children and adults. In 1834, he was among those called the "Lane Rebels" who influentially protested against the denial of free speech whenever citizens wanted to stop educational opportunities for blacks. During the 1850s, he became the editor of the Anti-Slavery Bugle. Robinson's Bugle was influenced by The Liberator and it adopted the slogan, "No Union with Slaveholders." For more information on Marius R. Robinson, see Russel Nye's excerpt in the Ohio History Journal. 
about the need to enlist children in abolitionism, though she enmeshes Horton's natural landscapes into her message. In 1865, Child published her book intended for freed people. She asked that "those of you who can read will read it aloud to others" (5). Her intentions were to give the book to the Freedmen's Aid Association for schools for black freed people; however, according to Robert E. Butchart, her book was only available to some black schools in New Berne, North Carolina, a couple of hours from Horton's home (126). Child envisions uplift for freed communities by articulating friendship through a different context - the natural landscape. Horton's poems provided a useful context for her articulation of friendship with the natural environment. This shift in audience and purpose prepares a new identity for blacks to imagine environments where they can hone their individualism in shared spaces amongst one another. In her biography of Horton, she places importance on the lack of sufficient funding for Horton and calls out his "friends" while doing so (113). Follen and Child situated a critique of friendship within their publications to assert a different form of abolitionism - friendship that places importance on imagined communal ties toward one another. She supports this theory by suggesting,

...I hope it will comfort his poor, bruised heart to know that some of his verses are preserved, and published for the benefit of those who have been his companions in Slavery, and who, more fortunate than he was, have become freemen before their strength has left them. (113) Child's publication included "Praise of Creation" and "Spring," two poems focused on nature from Horton's first collection. Unlike her predecessor who chose a sentimental poem, "Praise of Creation" does not reference slavery nor does it include any mentioning of liberty. Instead, it provides stanzas in alternating rhymes that literally praise earth and people. It begins by stating, 
"Creation fires my tongue!/ Nature thy anthems raise;" (73). Invoking the natural world through the creation story of earth forms the foundations of Horton's discourse on nature. Many of Horton's poems on nature avoid placing a hierarchy in the natural world, especially between enslaved peoples and farm animals, yet this particular poem does. For instance, the next lines reinforce the creation of man story that is in the Bible: "Heaven's chief delight was Man/ Before Creation's birth - / Ordained with joy to lead the van, / And reign the lord of earth" Child, aware of the stigmatization of enslaved people as animals, placed this in her collection to show the equality of all human beings. Through an unnamed narrator, one cannot place a race onto the narrator, causing an equalizing effect. Though Horton alludes to Adam, he never places a name to who "hailed the morn without a groan/ Or one corroding thought" (73). This mystery and unnaming appealed to Child as she wanted freed peoples to understand their equality in the world. Without an affixed name, the narrator could be any newly freed person. With this empowerment comes a sense of realization of their "reign" on earth. Her goal within her school book was to educate freed peoples through an anthology of works she thought helped uplift the race. Choosing two poems focused on the creation of the earth and the beginning of life has connections with the discourse surrounding liberty, though it is more focused on the building of landscapes and community for the empowerment of freed peoples.

Horton's next poem, "Spring," does not mention humans, but the interactions between natural beings on the earth. This poem in a romantic form celebrates the coming of Spring through the little enchanted beings of the earth. For instance, the "birds, proclaim that winter's gone!" and the "harmless" dove "coo[s] sweetly" (205). Even the streams and valley instill themselves with life. Everything in the poem prepares for the coming of Spring. In likely manner, Child circulated this poem to explain the coming of a new era for enslaved peoples. 
They are able to take up new beginnings and life much like "The male of birds who escorts his bride" (206). The friendliness and airy vibe this poem created reinforces the foundational concepts behind friendship. Agreement, orderliness, and a sense of purpose and liveliness pour into the natural surroundings in Horton's poem. Romantic nature provides a window into the community that Child envisions for newly freed peoples. The vision is hopeful and full of promise. Unlike "Praise of Creation" where earth is subject to humans' reign, this poem envisions equality among all beings. Alternating between the visions of a community found in "Praise of Creation" and "Spring," Child reveals potential realities for the destitute in the South, especially since the black codes were enforced in southern states. Though naïve, this vision provided some frame for mobility and might have inspired some freed children in North Carolina.

\section{Bridging Communities through Horton's Poetry in the Twentieth Century}

In the twentieth century, Horton's reputation as the first published black poet in the south retrieved for him recognition in some publications, especially those designed for black authors. The same themes of morality, teaching, and community building were interspersed in White and Jackson's An Anthology of Verse by American Negroes (1924). This anthology included Horton's "Meditations on a Cold, Dark and Rainy Night" from his second volume and "Praise of Creation" from his first. As a poet with the reputation of bridging communities during abolitionism, Horton's poetry secured a similar reputation during Jim Crow. For example, Horton's poems animated human feelings and experiences in words that readers, no matter their race could feel. As segregation plagued classrooms in the 1920s, a sense of shared values amongst races dwindled. However, Horton's poetry fostered a communal element by mapping out a common experience most humans feel before embarking on a new work day. His poem 
also lauded the creation of humanity, a story most students were familiar with. With the help of the fervent of the New Negro Movement, which bolstered confidence in African Americans, White and Jackson used Horton's poem as a way of shaping positive attitudes toward black poets. To teach students community building through black poetry's influence, White and Jackson reflected earlier efforts of abolitionists' who taught friendship as a way of community building. Horton's poetry not only offered windows into a form of desegregation in anthologies and classrooms, it offered a space for black students to imagine community building amongst themselves and with their white counterparts.

Horton's two poems, which focused on natural landscapes spoke to the needs of black readers and their ascension toward respectability. The need to speak about the same natural elements that propelled many Romantic poets of the previous two centuries into prominence gave way to anthologies such as White's and Jackson's. They valued poems that showcased an extensive vocabulary, rhymed and was written in verse form (4). Poetry that did not fit that description, such as Jupiter Hammon's, they labelled, simple and crude, yet deserving consideration due to his circumstances (4). As this description reveals, residual cultural values of poetry were still in existence during the early twentieth century. Benjamin Brawley, for instance, complained about the lack of "imagination expressed in intense, condensed, vivid and suggestive phrase" in black poetry and wished black poetry rivaled Tennyson and Keats (Brawley, Journal of Negro History 391). White and Jackson later explained that early poetry from Jupiter Hammon was "without any of the subtler qualities that distinguish poetry from prose" (4). "Meditations on a Cold, Dark, and Rainy Night" equips black and white students with tools for understanding verse and form. Since Romanticism was considered a high art form, it helped distinguish Horton's poetry. Essentially, White and Jackson taught black students romantic verse 
as an important element to their upward mobility. With education, these editors felt white society accepted black students.

The reception of Horton as an educational children's poet was revived in 1996 when Faith Jaycox published Ebony Angels (1996) and circulated Horton's "Praise of Creation." Jaycox included illustrations intended for youthful readers. Its premise was to feature poetry and prose by prominent black figures since "belief in divine messengers and guardians is certainly not limited to people of European heritage" (Jaycox). A mixture of contemporary and early poets is featured in the contents page of this collection. Horton's popular poem, "Praise of Creation" once again takes center stage in educating children on "piety, poetic aspiration, and love of nature" (Sherman 14). The poem's popularity in the twentieth-century could be attributed to the way Horton's poetry performed Romantic ideations of nature for uplift ideology. Respect for all living and non-living beings infuses the lines as readers browse its many references to eagles, landscapes, and lions. Jaycox borrowed the same natural references in high western literature that contributed to children's sense of education. Children could easily grasp its simplistic rhyme scheme and even memorize it.

\section{Connecting the Threads-Horton in the Twenty First Century}

Primarily, in the twenty first century, the major lines of discussion of Horton's poetry focus on his imitative style. Faith Barrett's work shows the dimensions of Horton's protest poetry as he weaves through and navigates the racial terrains of the publishing industry. However, this line of work neglects two understudied histories - editors used Horton's poetry to discuss black identity alongside pastoral scenes and they circulated his work to children. Remnants of one of these histories appear today as editors use Horton in children's books to 
celebrate his accomplishments ${ }^{47}$ This circulation history stems from earlier articulations of Horton's oeuvre, though the poems that were once popular during the nineteenth century, with the exception of one, fade from memory. "Praise of Creation" for instance, has stood the test of time and has contributed to teaching verse and rhyme to students based on its merit. However, twenty-first century scholars tend to neglect it in favor of "On Summer," which has been cast as a protest poem. ${ }^{48}$ Horton's didactic message in "Praise of Creation" could dissuade contemporary scholars from including it, though its importance in the late nineteenth and early twentieth centuries prove that it carried a message of protest to students. For Child, it promoted an understanding of community that helped freed peoples imagine a broader connection and understanding of their place on earth and with each other. The type of empowerment that she felt it brought is not the empowerment that contemporary scholars see. However, given the current Michigan water crisis and continual Dakota Pipeline protests (among many others), Horton's poetry on empowerment with natural resources seem more pressing than ever. Horton's poetry as understood by abolitionists helped reformers and allies understand the concerns of underrepresented individuals in communities fighting for their basic human rights. It provided a basis for empathizing with and supporting communities in danger. It also provided a view of underrepresented human beings in control of the environment which shapes their identities.

After slavery, Horton's poetry was soon forgotten as no one sought slave poets whose poetry influenced the now defunct abolitionist cause. Horton also disappeared from literary

${ }^{47}$ See Don Tate's Poet, a biography for children.

${ }^{48}$ Katherine Lynes argues that "On Summer" "protests against enforced labor on the land... [and] expresses joy at experiencing natural processes" (53). 
circulation because of Reconstruction era politics, which often placed harsh laws on blacks and made it harder for them to publish literature during this time, with the exception of Frances Ellen Watkins Harper. Even during the twentieth century, critics regarded Horton as imitative of English poetry and continued to keep his work from circulating broadly. Their aims to establish a definitive canon for African American literature were based on how well the poets could represent blackness. ${ }^{49}$

Despite these odds, one of the foremost mid-and-late twentieth-century pioneers of Horton's biography and poetry, Joan Sherman, produced two anthologies which featured explanations and critical attention towards Horton and included several obscure poets. Although Richard Walser produced a scathing biography of the poet's life in 1966, Sherman worked to rectify Horton' reputation. ${ }^{50}$ Her 1974 edition of Invisible Poets explains the need to broaden understanding of black poetry in "Anthologies of Afro-American literature" (vii). Many anthologies she explains felt that black poetry began with Phillis Wheatley and disappeared for over a hundred years and reappeared with Paul Laurence Dunbar. She seeks to narrow this gap and the narrow understanding of black poetry associated with it. She included several of Horton's poems in her collection of obscure African American poetry of the nineteenth century. Near the end, she recognizes Horton as a naturally talented poet who had "a perfect ear for rhyme, and a sensitive, often cynical awareness of what life, and thus poetry, was all about" (19).

\footnotetext{
${ }^{49}$ See the Introduction and Chapter 1 for an explanation of twentieth-century critics who sought to establish a predominantly male and protest-oriented canon for African American literature. ${ }^{50}$ See Walser's The Black Poet
} 
She concludes that Hope of Liberty was admirable among the three volumes he published, setting a precedent for future anthologies to collect from this volume.

Almost twenty years later, Sherman published a new anthology entitled AfricanAmerican poetry of the Nineteenth Century and included several of Horton's poems. By this time, Horton's appearance in anthologies had declined, possibly because mainstream anthologies did not regard Horton as an exemplar of verse. Nevertheless, among his poems, she includes "Praise of Creation" "On Summer" as well as other less frequently circulated poems. These poems granted scholars access to "On Summer" in the twenty-first century to critique conceptions of the land. Sherman's work in bringing attention to new ways of conceptualizing African American literature is no less than astonishing.

From Horton's compositions in his head to how he is valued for his Civil War poems, his circulation history reveals unique facts about his perception of himself as well as the ways others perceived the slave poet. Oftentimes, morality bridged the ways Horton's poems were diffused into the public to either teach citizenship among black readers, or friendship among black and white children. Later, Horton's reception history took a major turn as editors focused on the communal fortitude that it brought for distressed communities. Child recognized Horton's southern landscapes and used them to help bring a future of community building for black children in North Carolina. Though her vision was set to sights beyond North Carolina, the vision she had produced of Horton carried into the twentieth century when editors later chose Horton's use of natural landscapes and placed it in their anthologies geared toward a better understanding of African American literature. Today, the values that Horton's poetry for children once held no longer seem to be in play, though this line of criticism brings hopefulness with it in expanding understanding of black children's identities. 
High schools and college classrooms rarely use Horton's poetry, though it remained important in some classrooms in the nineteenth and early twentieth centuries. Toni Poling, a high school teacher from West Virginia, whom I interviewed and included in my previous chapter, mentioned that her school's textbooks on African American literature usually began with Phillis Wheatley and does not talk about other poets before Langston Hughes. In fact, the curriculum oddly mirrors the ways early twentieth-century black editors circulated poems from predominantly male, contemporary poets. Usually, editors such as Alaine Locke provide a brief historical accounting of Wheatley as the first black published poet, include a brief mention of her value only as a historical figure, then proceed to list Countee Cullen, Jean Toomer, Langston Hughes and Arna Bontemps, among other black male poets as exemplary poets. ${ }^{51}$ Similarly, Collections (2017), the official book for high school curriculums in West Virginia features a brief historical account of Wheatley's poems on freedom “To the Right Honourable William, Earl of Dartmouth" and "On Being Brought from Africa to America." The next time any black poets are mentioned is in the Harlem Renaissance section. A shortened list of the same poets is listed in this section, while no black women poets are mentioned. Considering Sherman's lament that most think black poetry began with Wheatley and then ended for 100 years, it is clear that a similar understanding of black poetry still pervades classrooms.

Though much recovery work has been done by many scholars in the field, the disconnect between teaching that work and helping students understand the importance of not only understanding its cultural and historical significance, but its use value today is troubling. Enriching humanities students with the type of archival research that scholars do is important for

\footnotetext{
${ }^{51}$ This is especially true for Locke's anthology, The New Negro (1925).
} 
the health and diversity of African American literature. Horton is important for what his speeches and poetry offers to our understanding of humanizing black children, enlisting children in the fight for abolition, and providing black Americans with ideas of citizenship.

The field's longstanding relationship to race and the ways scholars have employed it in their twenty-first century theoretical frameworks have blinded us to the possibilities that arise beyond adult agency and protest. One such scholar is Kenneth Warren, whose What Was African American Literature? (2011) argued for a reconceptualization of the field. He argues that antebellum literature was not African American literature until post-bellum writers retroactively made it so to bring a sense of a connectedness against Jim Crow. He explains that an author's racial identity does not denote that his or her works belong to a specific literature. Warren's premise hinges on the observation that Jim Crow laws and their earlier formations helped create a distinct form of African American literature that created an "imperative to produce and to consider their (writers') literature as a corporate enterprise (18). Scholars Lara Langer Cohen and Jordon Alexander Stein disagree with the idea that there was not a collectiveness before Jim Crow, however, they do agree that the field could use a refreshed view of the ways we've racialized texts. Race is dynamic and should not be confined to adult agency and protest. As Cohen and Stein relate in their collection, Early African American Print Culture (2014), African American literature is not defined so much by race or racial identity, but by print's role in the process of racialization (Cohen and Stein, Early 6). My work intervenes in this conversation by showing how the reception of Horton's works play a role in racialized understandings of friendship, morality, and citizenship.

His legacy as children's poet has long been ignored partly due to print's role in the process of racialization. His desires for others to recognize him as a serious poet and orator 
launched him into the unpredictable world of print where abolitionist- and white-owned presses determined representations and misrepresentations. For Horton, this meant that his work could only be appreciated in contexts where race defined intellectual ability. Unfortunately, this narrow category especially in the antebellum period, gave rise to an identity that Horton kept with him even after his emancipation. Not just a poet, but the words "Negro poet" appeared in many newspapers. This separate category afforded Horton the opportunity to publish his work, but not without restraints. 
“To educate is to 'educare:"' Frances Harper's Educational Poetics and Reception as a Children's Author ${ }^{52}$

Frances Ellen Watkins Harper (1825-1911) has in recent decades gained considerable attention for her remarkable abolitionist and women's rights initiatives; it is rare, however, to find attention given to her efforts to educate children. ${ }^{53}$ In recent years, Karen Kilcup and Angela Sorby have dedicated an anthology, Over the River and through the Wood: An Anthology of Nineteenth-Century American Children's Poetry (2013) to acknowledge children's poets. Both editors include two of Harper's poems that focus on freedom and death. Karen Chandler even dedicates a chapter to Harper in Who Writes for Black Children (2017), acknowledging her as a children's author. Even still, collections featuring children's poems are slow to include nineteenth-century African American voices.$^{54}$ Harper was respected and well known for her

${ }^{52}$ The quote is from M.H. Freeman's "The educational Wants of the Free Colored People" located in the Anglo-African Magazine, April 1, 1859.

${ }^{53}$ Among the many organizations Harper played a role in, some of them included a YMCA Sabbath School in 1872, to which she was a founder and assistant superintendent and the American Association of Education of Colored Youth in 1894 of which she was the director. See John Hollander's American Poetry: The Nineteenth Century 888.

${ }^{54}$ Prelutsky's The Random House Book of Poetry for Children (1983) included nineteenthcentury authors such as Lydia Maria Child and Emily Dickinson but doesn't include Harper's poems. Also, Hollander and Comport's American Poetry: Poetry for Young People (2004) features Whitman and Dickinson among other nineteenth-century poets, but not Harper. 
efforts to educate black women and children. ${ }^{55}$ She gave lectures to southern black women who were "down trodden" and who no doubt had their children in attendance at lectures and meetings. ${ }^{56}$ Even Harper's own daughter, Mary (1862-1908), who was known for helping her mother do charity work at a young age, is left out of conversations involving her work with

${ }^{55}$ See the Anti-Slavery Bugle's September 29, 1860 issue where Harper publishes a letter to Mrs. Elizabeth Jones explaining her aims to "spend part of this fall visiting and lecturing among the colored people” (Harper “Letters”). Also see William Still’s Underground Railroad (1872) where Harper writes to a friend about "the untrained little urchins" she feels obligated to teach in Little York, Pennsylvania (Still). Harper strongly believed that all were involved in the "welfare of our race," and felt it her duty to teach children.

${ }^{56}$ See Jeannine DeLombard's "African American Cultures of Print” in A History of the Book in America, vol. 3. In her chapter, she explains the sheer numbers and diversity of blacks who sought education and literacy as a means of uplifting themselves. During and after the Civil War, efforts to build a systematized education for African Americans in the South were underway. In terms of how the group dynamics looked, DeLombard states, "Students in freedpeople's schools ranged from those 'too young even for the alphabet' to the elderly" (369). Harper no doubt was involved in efforts to educate such diverse populations, especially ones that Charlotte Forten Grimké speaks about in her journals. See Brenda Stevenson's Journals of Charlotte Forten Grimké 394 (Wednesday, November 5, 1862). Frances Smith Foster also relates that Harper "was especially interested in working with women and frequently conducted private sessions with them 'about their daughters, and about things connected with the welfare of the race"' (19). Also see Still's Underground Railroad 772-3 and 777. 
children during the Reconstruction period (Bacon, "One Great" 38). So why has this strand of Harper's legacy gone largely unnoticed when several publications point to aspects of Harper's involvement in teaching children poetry?

One reason is that scholars have overlooked the importance Harper placed on youthful readers' involvement in addressing social injustice. For example, Hazel Carby, the scholar credited for recovering Harper's work, astutely observes Harper's vision for women's transformative abilities in society. She explains that Harper regarded "the home as a crucial sphere of women's influence" (69). Unlike her younger contemporary Anna Julia Cooper, who emphasized the Victorian myth of women's moral superiority in her uplift ideology, Harper advocated for unity to achieve racial gains. However, Carby focuses less on explaining the unity Harper advocated for and more on the ways women's fiction influenced Iola Leroy (1892). Carby limits understandings of Harper's appeal to justice and humanity by focusing solely on the ways the literature spoke to adults. Some historical issues may hinder scholars from noticing Harper's involvement with children's literature. One reason was that after the turn of the century, black male elites dictated what the literature of the "New Negro" encompassed. They excluded sentimental literature from their constructions. Also, black children's magazines such as The Repository of Religion and Literature and Science and Art (1858-1863), were short lived. Black women such as Harper and Sarah Mapps Douglass who contributed to these magazines could not do so for an extended period of time..$^{57}$ Contemporary constructions of childhood may also blind

${ }^{57}$ According to Rudine Sims Bishop's Free Within Ourselves: The Development of African American Children's Literature, The Repository was edited by Bishop Daniel Payne of the 
scholars to more nuanced historical constructions of childhood. Nevertheless, Harper's letters and poetry reveal that she included children in her appeals to justice and humanity.

In her travels to the south from the end of the Civil War until 1871, Harper lectured to impoverished freed blacks in Sunday Schools. The work was grueling; Harper details the living conditions of southern blacks during Reconstruction and the dilapidated homes in which she visited and lodged.$^{5}$ While there, she held meetings with women and addressed Sunday Schools where children were in attendance..$^{9}$ Though many of her letters do not detail the specifics of what she taught during her meetings with women and children, they do point out tenets of what she valued as an activist for social justice. For instance, Harper sums up her dedication to the eradication of social injustice well in her letter, "A Private Meeting with the Women" (1870?), which makes references to her intentions of training children in political matters:

A.M.E Church and included poetry from Harper. There is only one extant issue of the magazine available at Harvard's Houghton Library, and the microform versions are non-circulating. ${ }^{58}$ See Harper's letter, “As Full as the Room Was,” December 29, 1870. In this letter, Harper speaks of the crowded conditions of one home and the "wail" of possibly children whom she shared sleeping spaces with. Though Harper speaks on the uncomfortable situation she endured, she does so to bring awareness to the impoverished living conditions of southern blacks. ${ }^{59}$ See Harper's March 1871 letter entitled "What a Field There is Here" where she describes a busy week of lecturing to women, children, black and white audiences. Also see "A Private Meeting with the Women," Harper's March 29, 1870 letter in Frances Smith Foster's A Brighter Coming Day (1990). 
Well, after all perhaps the colored man generally is not really developed enough to value his vote and equality with other races, so he gets enough to eat and drink, and be comfortable, perhaps the loss of his vote would not be a serious grievance to many; but his children differently educated and trained by circumstances might feel political inferiority rather a bitter cup. (Harper, "Private Meeting” 128) Harper understood that the excruciating toil of reaching out to people of her race could not be done by adult individuals alone; children could help with reform as well. Through education and uplift, Harper sought to instruct children on the importance of embracing a changing society where blacks were politically equal to whites. Poetry, which was a mainstay of nineteenthcentury schools, was the vehicle through which Harper influenced child readers and thinkers. ${ }^{60}$

In the following chapter, I trace Harper's reception history to argue that she played a large role in debates about holistic education for children and reflected her ideology through her poetry. She used popular constructions of childhood to insert criticism about them and to make her audiences aware of the missing black voices from early constructions. The black and white press helped shape Harper's identity as a children's poet by circulating poems that responded to growing anxieties about child-rearing in the nineteenth century. However, by the twentieth century, Harper's literary aesthetics and gender barred her from collections by black male critics who sought a changing literary aesthetic that they deemed more fitting for the new century.

${ }^{60}$ For discussions of the performance of poetry and the fireside poets in schools, see Angela Sorby's Schoolroom Poets. Poetry was a vehicle through which students could aspire to middleclass values and was used to show one's education and training. Successful recitation of poems meant that one gained a cultural assimilation to the nation and its educational institutions. 
Through the efforts of feminist archival work, Harper's poetry resurfaced and proved timeless and important for decades to come. Strands of her children's poems are beginning to circulate even into the twenty-first century, even though she still remains on the margins of most children's poetry collections.

Debates about black children's education took place in black newspapers such as the Anglo-African Magazine. Daniel Alexander Payne, M.H. Freeman, and Harper, all contributors and major players in the magazine's success, argued in favor of an education that encompassed more than simple facts. Education for black children needed to be a "harmonious development of the physical, mental, and moral powers of man" (Freeman 115). Harper's and her contemporaries' accounts of education were steeped also in various religious and transcendental ideals of their day. However, contributors differed over how to teach those ideals. For instance, in the 1859 issues of the Anglo-African Magazine, Freeman emphasized wealth as an "educating power" that taught children self-respect and self-reliance (116). Freeman reasoned that white children were able to develop these characteristics because their parents held high offices in the country. Lacking the same opportunities, black children did not experience holistic education from these "outside sources" (Freeman 116).

Payne and Harper disagreed with this emphasis on wealth as the primary focus for educating children. In a follow-up to Freeman's post, Payne suggested that wealth and its accompanying power did not impart knowledge or self-reliance and self-respect to people. He argued that black Americans accepted too quickly the tenets that were taught to the ruling class without considering our own unique circumstances, which require different approaches (118). Harper agreed in "Our Greatest Want," published in the May 1, 1859 issue and delineated her ideas about what black Americans need most: 
[I]t does not seem to me that money, as little as we possess of it, is our greatest want...If I understand our greatest wants aright, they strike deeper than any want that gold or knowledge can supply. We want more soul, a higher cultivation of all our spiritual faculties. We need more usefulness, earnestness, and integrity. Our greatest need is not gold or silver, talent or genius, but true men and true women. (Harper, "Our Greatest Want” 160)

The letter espouses late-Victorian bourgeoisie values for black upper-middle class mobility, yet Harper did not fully accept the tenets of true womanhood. Barbara Welter explains that the Victorian-era's idea of true womanhood equaled happiness and power within the domestic setting for white women. Women must be pious, pure, and submissive (Welter 152). The ideology pronounced that white women's strength was in their piety and society believed that they had a natural purity that improved debased men (Welter 152). Many black elites adopted these tenets as middle-class markers of racial uplift (Gaines 142).

Even though the very racial uplift ideology that Harper and other black elites adopted contributed to class and gender hierarchies within black communities, Harper found ways in her speeches and poetry to adjust it. Kevin Gaines explains that many middle-class blacks adopted the Victorian myth of women's moral superiority in their racial uplift ideology (142). Harper stated that she "was not sure that women are naturally so much better than men" and that "it is not through sex but through character that the best influence of women upon the life of the nation must be exerted" (Harper, "Woman's Political Future") After all, by the time of her letter, uplift ideology in the antebellum period "signified both the process of group struggle and its object, freedom" (Gaines 21). It was not until the beginning of Jim Crow laws that blacks revolutionized racial uplift to include "evolutionary racial theories positing the civilization of elites against the 
moral degradation of the masses" (Gaines 21). In other words, Harper infused Christian and Enlightenment ethics into her philosophy of racial uplift. After the Civil War, her poetry adhered to the "conservative civilizationist, self-help ideology that, by the 1890s, endorsed educational and property qualifications for citizenship" (Gaines 21). Still, Harper devoted time toward educating children. In her speech, "The Great Problem to be Solved” delivered at the Centennial Anniversary of the Pennsylvania Society for Promoting the Abolition of Slavery on April 14, 1875 , she explains to youth, "Woman in your golden youth...let no magnificence of culture, or amplitude of fortune, or refinement of sensibilities, repel you from helping the weaker and less favored" (qtd. in Foster 221). Harper's goal was to refine the character of youth so that they too could work toward racial uplift.

“Our Greatest Want" also showed awareness of nineteenth-century constructions of childhood for white and black children. White adults characterized black children as the pickaninny, an imagined grotesque stereotype that dehumanized black juveniles. The image, Robin Bernstein explains, originated from the character Topsy in Uncle Tom's Cabin (16). The pickaninny characterization justified the abuse of black children because it robbed them of the same construction of childhood innocence as their white counterparts. Harper, however, borrowed from depictions of white child innocence to shape successful black children. The era's obsession with depictions of blacks as corrupt, docile, and insensate may have made the rhetoric of innocence attractive in Harper's attempt at humanizing black children. In the latter half of the nineteenth century, white adults constructed childhood innocence, a romantic concept reserved for white children. The white child was fundamentally innocent, pure, and was often depicted as angel-like (Bernstein 39). Harper uses these themes in her poems to articulate a method for engaging black childhood. More particularly, I borrow from Bernstein's idea of the 
performativity of passionlessness to explain how Harper used white constructions of childhood innocence to promote black children's humanity. Bernstein's concept emphasizes how child bodies in performance possessed the abilities to present domesticity - that is the abilities to be asexual and to be pure. Harper recycled these constructions and presented them through the lens of social justice so that black children could gain humanity in white society.

In the Anglo-African Magazine, black contributors emphasize service to one's race when constructing black children's education. In November of 1859, Amos Gerry Beman asked in the Anglo-African Magazine, "who shall teach and educate them [black students], and fit them for their sublime mission in this world, or for a glorious destiny in that world which is to come?" (338). Like Harper, Beman explained that black Americans had to have a tailored education that was based in "truths and principles fitted to arouse, energize and inspire us to do those things upon which the permanent welfare of the colored race depends" (339). In these texts, black writers showed a concern for childhood education that is steeped in more than just uplift and religious commentary; Harper, Freeman, Payne, and Beman engage with transcendentalist ideals of self-reliance while fashioning a unique form of education for black children. ${ }^{61}$ These

${ }^{61}$ For a discussion of black intellectual thought and transcendentalism during the abolitionist movement, see Peter Wirzbicki’s “Black Transcendentalism: William Cooper Nell, the Adelphic Union, and the Black Abolitionist Intellectual Tradition.” William C Nell's work was often published in the same newspapers (The Liberator, The Christian Recorder) as Harper's work, which attests to the ways black abolitionists engaged with ideas on transcendentalism and uplift or "elevation" as Wirzbicki calls it. In this article, Wirzbicki explains the connections between prominent black historians and lecturers such as Nell who often mingled with Bostonian and 
constructions were meant to influence the ways teachers taught children in schools and which teachers were qualified to uplift black children. This overlooked history shows the importance of black intellectuals' efforts in constructions of childhood and black children's education.

Despite the evidence of Harper's repertoire which includes many children's poems, her meetings at Sunday Schools, and letters that directly address the influence that children had on her life and activism, we still fall short of representing this unique strand of Harper's life. ${ }^{62}$ Karen Chandler calls for scholars "to see and hear the range of Harper's own achievement as an activist writer" by "working to uncover the writing that she produced for children and families" (53). In Chandler's adept analysis, she uncovers the dimensions to Harper's activism by providing four poems focused on children that she argues prove that Harper wrote for them. She approaches doing so by understanding the contextual and textual components through which

New England Transcendentalists. The Boston-based literary society and lyceum, the Adelphic Union, often hosted lectures and brought white transcendentalists (William Henry Channing, Theodore Parker, Karl Follen) to speak on education, religion, and moral and political issues. Nell also worked at the Town and Country Club in Boston, which was founded by Ralph Waldo Emerson and others (284). In 1867, Nell took a day trip to Concord in Walden Woods, where he saw A. Bronson Alcott, Franklin Sanborn (first biographer of Thoreau), and Emerson (285). ${ }^{62}$ Harper's repertoire of poems that are about children include, "The Slave Mother," "The Drunkard's Child," "The Slave Auction," "Advice to the Girls," "The Contrast," "Days of my Childhood," "Youth in Heaven," "Thank God for Little Children," "To a Babe Smiling in Her Sleep," "The Little Builders," "Save the Boys," "My Mother's Kiss," "A Little Child Shall Lead Them," "Jamie's Puzzle," and "The Martyr of Alabama” This list is not exhaustive. 
Harper "conjured" young black readers. ${ }^{63}$ She searches for the ways Harper imagines a young black readership who received "Thank God for Little Children," first published in Lydia Maria Child's The Freedmen's Book (1865), “The Little Builders,” first published in Poems (1857), “The Dying Child to her Blind Father," (1857) and Harper's religious poems. Conjuring in this sense is useful for understanding contextual components of Harper's poems. However, this approach does not fully account for the differences in the ways black and white newspapers circulated Harper's education poetics. For black newspapers, Harper's poetry solidified best practices for training and rearing black children that often challenged the pickaninny characterization. As far as white abolitionist publications, editors often used Harper's education poetics to uphold white constructions of childhood, even when her poetry subverted these constructions. Due to Jim Crow laws which enforced disdain against black education, her poetics were no longer needed in reshaping education reform for all children. Parsing out these nuances in the ways that black and white editors circulated her poems paints a fuller picture of how Harper was a noted children's author in her community, but not so much outside of it. Editors of publications such as the Anglo-African (1859-1865), the Anti-Slavery Bugle (1845-1861), The Black Man (1863), The Freedman's Book (1865), Ebony Angels (1996), and Over the River and

${ }^{63}$ See Angela Sorby's “Conjuring Readers" in Who Writes for Black Children. Sorby articulates a mode for modern readers to understand the ways black child readers received black literature in the nineteenth century since black child readers "are hard for literary historians to document, and in many cases, they were also hard for antebellum poets to reach, or even picture" (3). Conjuring is a way of imagining a literate black child reader. 
Through the Woods (2013), who circulated poems about children for child and adult audiences alike, disrupt our ideas about who these poems served and for what reasons.

\section{Harper's Publications and Legacy}

Harper's publication record indicates a young life of intense reading and education. After leaving the Watkins academy, Harper was employed as a domestic worker where she was allowed to read in the Armstrongs' bookstore. Sometime in the latter half of the 1840 s, she published Forest Leaves, which was recovered in 2015 by then graduate student Johanna Ortner. This collection featured many religious poems of varying topics, and a couple of poems about love. A shortlist of other publications by Harper include a poetry collection, Poems on Miscellaneous Subjects (1854), an extended, blank verse poem, Moses: A Story of the Nile (1869), a collection of poems entitled, Sketches of Southern Life (1872), and a novel, Iola Leroy (1892). Harper advocated for formal education for children because she saw it, like many other advocates, as a "necessary path toward full citizenship and toward participation in a capitalist democracy" (Murdy 77-8). Because of her advocacy for children, newspapers also used her poetry in their own endeavors to teach children.

The Anglo-African (1859-1865) promoted this strand of Harper's legacy by circulating "Youth in Heaven." In this poem, Harper imagines how children create an ideal society and address the injustices for generations to come. "Youth in Heaven," published in February of 1860 in the Anglo-African Magazine (1859-1865), reimagines the fight for equality by positioning child-like "angels" to thrive in a space where "Life's new spring for them arrives." This new spring works as an Eden of sorts where "length'ning shadows" never fall "coldly" around their lives as the shadows do for the assumed adult narrator. Given white society's propensity to represent black children as insensate pickaninnies in the nineteenth century, the 
fact that a black magazine published a poem representing children as angels signifies a move toward challenging negative representations. Building from Bernstein's analysis of angelic white children deflecting markers of gender, class, or sexuality, Harper's poem presents similar tactics for black children. Angelic black children could perform innocence and deflect the "length'ning shadows" or turmoil of a "loveless age" in order to thrive in a world where "the streets of life doth never/Cross the mournful plain of death" (Harper, "Youth in Heaven" 172) The narrator makes several laments about the world she inhabits while contrasting it to the "heavenly" world that the youth create. The spring, as mentioned in Harper's first stanza represents a beginning or renewal and does double duty to represent the promise of youthful interceptions in an "loveless age" (Harper, "Youth in Heaven" 171). Each stanza continues with laments of a lost world, but the promise of a new beginning with children who orchestrate it.

An avid abolitionist, editor, writer, and broker (in the sense that he brought many talented and famed blacks together in his journal), Thomas Hamilton founded the magazine in 1859 in New York at 11 Bleeker Street. ${ }^{64}$ In his introduction to the first issue entitled "Apology," Hamilton claims he wants his magazine to be "one of the institutions of the country" (1). He held high regard for his venture into providing a voice for and to African Americans and his claims of making his newspaper an institution spoke to the issues surrounding the black press and communities. The United States held low opinions of blacks, mostly through race science, a popular form of categorizing races of people according to various "inherent" traits and

\footnotetext{
${ }^{64}$ Some of the writers who contributed works were Alexander Crummell, Mary Ann Shadd Cary, Sarah Mapps Douglass, Frederick Douglass, Martin R. Delany, William Wells Brown, John Mercer Langston, Frances Harper, Daniel Payne, William J. Wilson, and James McCune Smith.
} 
characteristics.$^{65}$ Because this science had taken a powerful form of cultural legitimacy, Hamilton saw that "'the twelve millions of black in the United States and its environs...must speak for themselves" (1). He continues:

...no outside tongue, however gifted with eloquence, can tell their story; no outside eye, however penetrating, can see their wants; no outside organization, however benevolently intended, nor however cunningly contrived, can develop the energies and aspiration which make up their mission. (1)

Hamilton sought literary voices for and by blacks that could portray the wants, aspirations, and stories of black Americans. This endeavor called for a myriad of voices from African America to fulfill this goal because as John Ernest relates, "the Anglo African Magazine is a dazzling collective performance, an assembly of history... as well as a careful assembly of the many dimensions of the African American experience" (306). Harper's works represented aspects of this multifaceted experience for African Americans and her philosophy on education is reminiscent of the ongoing struggle for nineteenth-century blacks to decide on an education suitable for black children.

"Youth in Heaven" poses a response to ongoing debates about what an education for black youth looked like in the nineteenth century. Harper's poem, placed ten months after the debates between her, Freeman, Payne, and Beman reveals her holistic approach to education that

${ }^{65}$ Space doesn't permit a discussion of the various and popular forms of race science, but Britt Rusert's “The Science of Freedom: Counterarchives of Racial Science on the Antebellum Stage" takes a look into the ways race scientists performed their science and the ways black performers resisted these interpretations. 
embraced the challenges of an elevated self and helped students understand the U.S.'s discriminatory system. ${ }^{66}$ In "Youth in Heaven," youth inhabit a society full of love and light and experience little-to-no grief that adults in the poem do experience. Reminiscent of Emanuel Swedenborg's Heaven and Hell (1758) (from which Harper quotes at the beginning of the poem), this Heaven or ideal world embodies traits that human beings could possess through service to their community. Like Swedenborg, the more one loves, provides charity, and has faith, the happier and more youthful they will be (Swedenborg 257). Death and "his icy breath" is only metaphorical - only those who "cross the plains of death" are those who remain stagnant and watch their "dearest hopes go by" (Harper, "Youth in Heaven" 172). Posed as a cautionary tale, these lines warn black children to participate in social justice; one's character was also on the frontlines for improvement. Without these two important missions, existence was hopeless. According to Swedenborg's text, helping others and service creates this mind-state of heaven where these angel-like beings, or human beings, can exist (275). Hell is for those who hurt others

${ }^{66}$ John Ernest does an in-depth summary of the debate between Freeman and Payne in Liberation Historiography: African American Writers and the Challenge of History, 1794-1861. (2004). Both writers believe that education for black children should be tailored to fit the character and circumstances of the black race, though Freeman believed that wealth and education ensured power for black children. Payne disagreed by arguing that knowledge is first priority and that wealth without knowledge causes black children to be educated fools (Ernest 318-19). Ernest argues that Harper's philosophy mirrored Payne's. I agree and my analysis of her speeches and poetry show a similar ideology on black children's education. Also see the April 1859 issue 4, 115-119 of Anglo-African Magazine. 
and do disservices to the human race. Harper uses Swedenborg's revelations about humanity and divinity as a springboard to offer a vision of education that does not only place importance onto knowledge, but onto one's moral composition.

While Harper's philosophy took root in black publications as a means of articulating a black-tailored education, it served a different purpose for white-owned newspapers such as the Anti-Slavery Bugle. For The Bugle, this poem taught adult audiences the significance of children's inner lives and the struggles of black childhood. The Bugle published Harper's "Days of My Childhood" in its September 29, 1860 issue among a page of other publications about children. Published only seven months after "Youth in Heaven," this poem about adults and children appears among an array of informative writings regarding stories of abandoned babies, the uselessness of corporal punishment for children, and the examples parents should set for their children. Labelled as a part of the "Miscellaneous" section, Harper's poem begins the page's insights into childhood. Within this context, the poem reminds adults about their fading youth and about the power they gain from this realization. Though youth may encompass energy and bliss, the narrator claims that she rather have the wisdom gained from her years of strife. The context in which the editor situated this poem shows that he chose this poem for adults to understand the roles they play in imparting knowledge upon youthful learners. This dynamic allows adults to recognize their truths and can apply their knowledge in the service of cultivating children's wisdom.

A philosophy set on the power and strength of children's inner being reflects the constructions of childhood that The Bugle held, and the ways Harper's poem supports it. The editors show their concern for the arguments surrounding childhood by implementing texts related to children. These texts not only gave advice for rearing children, they bolstered a 
constructed essence that provided adults a way of understanding them. This essence defined adults' relationships to children - children could teach adults about morality by simply being a child; adults imparted wisdom by way of accepting this essence into their own lives. A good example of this relationship appears in Nathaniel Hawthorne's "Little Annie's Ramble," which was chosen for the Miscellaneous section of the 1845 issue. After spending a day with Annie, the adult narrator's child-neighbor, the narrator argues that children can revive the moral nature of adults (Hawthorne, "Little"). He explains that "After drinking from those fountains of still fresh existence, we shall return into the crowd... with a kinder and purer heart and a spirit more lightly wise" (Hawthorne, "Little"). This "magic" is used in service to humanity and aptly allows adults to make the world more "true."

Echoing these sentiments, Harper's poem hints at the ways social justice begins in childhood. The poem details the ways adults harbor the essence of youthfulness through their service to humanity. The narrator explains that a life of truth keeps "round [the] soul the dew of its youth" ("Days of My Childhood"). Harper embraced service and morality as the paths to truth as reiterated in "Our Greatest Want." For adults to impart wisdom and knowledge, they too must embody what it means to be true men and women. "Days of My Childhood" purports the same philosophy; the only difference is that the focus now rests on adults' roles in changing society. By connecting education to racial uplift ideals of self-reliance and truth, Harper creates a philosophy for adults to use to understand childhood and their relationship to it. The ultimate goal for Harper is to have a society that is better for all beings, so that when she and her contemporaries are no longer living, the cycle of true men and women continues. Adults in this poem must fulfill their dreams with "loftier hopes" so that when they pass, "the angel of death shall set [them] free" ("Days of My Childhood"). In order for adults to achieve their own truths, 
part of their existence must recognize the innocence of youth. This constructed innocence comes from the realized ideals of human truth.

Acting as a voice for Garrisonian radicalism, The Bugle's mission was to "preach deliverance to the captive, and the opening of the prison door to them that are bound; to hasten in the day when 'liberty shall be proclaimed throughout all the land, unto all inhabitants thereof"' (Anti-Slavery Bugle, “Our paper”). Though primarily meant for debates centered on slavery, The Bugle not only influenced anti-slavery movements, it clearly showed an interest in the liberation of draconian ways of rearing children. Uplift, ideas of self-reliance, and Christianity connect and influence readers' perceptions of childhood in the confines of the Anti-Slavery Bugle.

Another way of reading "Days of My Childhood" in the context of a white abolitionist newspaper is to consider the way Harper constructs black childhood within the poem. In "Days of My Childhood," Harper dispels nineteenth-century qualities associated with "Childhood" to construct a useful model for thinking about black childhood. Around late-nineteenth century, adults considered white childhood separate from adulthood - that is, white childhood became synonymous with playfulness, innocence, and purity ${ }^{67}$ Black children could not have the same

${ }^{67}$ According to Robin Bernstein's Racial Innocence, "During the colonial period, Calvinists did not believe that children were innocent" (4). Adults needed to rear children because they had learned how to avoid sin. Around the early nineteenth century, an emergent view about children's innocence began to shape public consciousness. Children were now constructed as blank slates and uncorrupted by sin. William Wordsworth's representations of children as innocent, holy, and able to redeem adults gained favor among U.S. adults. Around midnineteenth century, sentimental culture intertwined with constructions of childhood and 
advantages of childhood innocence because white adults constructed them as pickaninnies. Therefore, Harper characterizes youthfulness in the final stanza as having love and pureness of soul, two human feelings that all black children could strive for. For adults and children to achieve this youthfulness, they must do service for humanity. The second stanza confirms this: "But who that has gazed on the true and right, /Should exchange them for childhood's laughing light" (Harper, "Days of My Childhood 93). Truthfulness and righteousness are obtained by acts of service and love, not by white constructions of innocence.

In "Days of My Childhood," with its stinging analysis of the nineteenth century's construction of childhood, the narrator reconnects the separation between child and adult through a reinforced vision of truth. This collaboration between child and adult changes our understandings of children's literature as the field has often separated child and adult spheres. For Harper, black children must consider adult issues, such as social inequality and fulfill services in the name of Christ. These are the elements that "keep round my soul the dew of its youth" ("Days of My Childhood"). Activism against inequality fueled many of Harper's lectures and meetings. Children who attended these meetings were challenged with the responsibility to

childhood became the symbol of innocence (Bernstein 4). However, this construction was only reserved to white children because they were seen as human beings whereas black children were viewed as objects and chattel. See also Angela Sorby's "Women Poets, Child Readers" 381. Though she speaks about Eliza Lee Cabot Follen's collections and how they embodied the changing ideals of childhood, Sorby's discussion on childhood in the mid- and late- nineteenth century is vital to my discussion about normalized expectations of (white) children around this time. 
uplift and serve their race. Harper deconstructs the ideals that prominent children's authors such as Eliza Follen and Mary Mapes Dodge created. Angela Sorby explains that prominent children's authors' verses and collections (or as prominent as this position could be in the nineteenth century) shared similar traits. The main three that Harper deconstructed were: 1) "they assume that the child is naturally redeemed; 2) they valorize non-teleological play; and 3) they imagine that adults should not... exercise too much direct power over children" (381). Harper enlisted black children in her efforts to reeducate them about their own survival and uplift. Harper cautions black children throughout the poem about childhood's "gilded dreams and toys," and instead teaches them that "loftier hopes and calmer joys" are the elements to strive for. Their journey looked vastly different from their counterparts. Essentially, Harper taught a form of intersectionality within this poem that breaks down the constructions of race and age and reconstructs them to better suit black children.

The poem inserted black children in spaces in which they had previously been denied and articulated who may belong to "Childhood." Because black children did not have the same opportunities for social uplift that white school children had, Harper proclaimed that social justice activism was necessary for their ascendancy into white society. ${ }^{68}$ Their means of

${ }^{68}$ In Thomas Hamilton's Anglo-African, a July 1859 issue details the stark differences between white and black schools in New York. The report Hamilton places in the magazine explains, "Their[blacks] money has been used to purchase sites and erect and fit up school-houses for white children, whilst their own children are driven into miserable edifices in disgraceful localities" (227). Please see volume 1, no.7 of this magazine. Note: This is also the same issue where Martin R. Delany's Blake: or the Huts of America appeared. 
education were through white organizations, free black teachers, or national and local black organizations that taught them in crowded spaces in the South, or in Sunday Schools. ${ }^{69}$ Especially in stanza two, Harper challenges what may be a white nineteenth-century adult's vision of childhood by contrasting it to one who does not belong to majority culture:

Childhood may boast of its path of flowers

Missing all the thistles and thorns of ours,

But who that has gazed on the true and right,

Should exchange them for childhood's laughing light. (Harper, "Days of My Childhood")

Significant to these lines is the use of "ours" in the second line, which begs the question: who belongs to this construction of "Childhood" and who doesn't? On one hand, one could make the argument that Harper refers to adults; however, it is naïve to believe Harper is unaware of cultural differences and racism. ${ }^{70}$ For these reasons, she places a differentiation between her life

${ }^{69}$ For historical context of black education in the south, see Ronald E. Butchart's Schooling the Freed People and Jeannine Marie DeLombard's “African American Cultures of Print" 369-370 in The History of the Book, Vol.3. For information about the different native schools developed in Virginia, Louisiana, and North Carolina, see James D. Anderson's The Education of Blacks in the South, 1860-1935 (1988).

${ }^{70}$ Harper became dissatisfied with women suffragists during her meetings with the Women's Rights Convention because she was acutely aware of the racism among white suffragists. In her 1866 speech, "We Are All Bound up Together," she proclaims, "You white women speak here of rights. I speak of wrongs. I, as a colored woman, have had in this country an education which has 
and those who belong to the experiences associated with Childhood in the next stanza: "Though the glittering dews of my early life,/ Have been pressed in the cup of care and strife,/ The silver of age mid my locks is spread..." (Harper, "Days of My Childhood”). By placing a distinction between the way her young life has been informed by "care and strife" and the lives of those who experience Childhood (a path of flowers), she critiques any easy association between the two, thereby, demystifying the myth of childhood for black children.

William Wells Brown chose “Advice to the Girls," published originally in 1854, and Harper's more famous poem, “The Slave Mother,” for The Black Man (1863). Thomas Hamilton published William Wells Brown's The Black Man in New York. It is not surprising that Harper appears in Brown's collection, since she was a well-known lecturer and poet during the time and had published previously in Hamilton's Anglo-African Magazine. What is surprising is Brown's

made me feel as if I were in the situation of Ishmael, my hand against every man, and every man's hand against me" (218). Harper articulates how her education as a youth prepared her to understand inequality and how her experiences differed from her counterparts. Not only is Harper battling sexism, she battles with racism - something her white counterparts are not aware of. Also, interesting to note in this speech is the narrative Harper gives about her "orphan" children once her husband died. This lament framed near the very beginning of her speech connects Harper to her audience of white women, though it still articulates the differences between her widow status and her white counterparts' statuses. She mentions in the very beginning, "Born a race of whose inheritance has been outrage and wrong, most of my life had been spent in battling against those wrongs," which establishes an automatic difference between the wrongs against Harper and the wrongs her audience experience as white women. 
decision to include a less popular poem, "Advice to the Girls," in his collection. Harper had gained popularity from anti-slavery poems, such as "The Slave Mother," and any black or white abolitionist editor in the early half of the nineteenth century included this poem. However, the fact that Brown included "Advice to the Girls" suggests his aims were not entirely based in antislavery work. This poem's inclusion requires more consideration because not only was this poem less popular, it was not included in Kendricks Levitt's anthology again until 1970 in AfroAmerican Voices, 1770-1970. Given Brown's desires to lecture on topics outside of abolition, it isn't farfetched to believe that his anthology also served to educate girls. Therefore, Brown's collection should not only be viewed as an anthology for adults, but for children as well. Historically, reading practices varied for black children and adults, especially when children read to their illiterate parents. The Black Man teaches us that we must complicate categories of children's and adult literature because if we do not, we exclude how the text influenced youthful readers to consider themselves citizens in white society.

The Black Man is an important contribution to Harper's legacy as a children's author for a couple of reasons. By the time Brown's collection was published, Harper had already made a name for herself through her work in the anti-slavery lecture circuit. Recruited in 1853, Harper lectured for the American Anti-Slavery Society from 1856-1860. In 1863, she was married to Fenton Harper and had retired from lecturing to raise her family. During these lectures, many remarked on her appearance, noting her skin color among other characteristics; no publications, however, have characterized Harper in the way Brown does in his anthology: "Miss Watkins... appears in all the simplicity of a child" (Brown, The Black Man 342). Brown's comment seems off-putting and demeaning, especially since she was about thirty years old. One reason he made it was to appeal to one of his desired audiences - girls. Brown was known for 
appealing to female audiences according to Paula Garrett and Hollis Robbins who argued that Brown often used a gentleman-style of address (xx). Therefore, commenting on Harper's demeanor grants Brown the opportunity to appeal to young girls who can identify with Harper's work. Brown himself had daughters (who at the time were young adults) and may have been thinking of them when choosing this poem. "Advice to the Girls" uses a third-person narrator that "preaches" to young girls about their choice in men. By writing that this poem should be appreciated by all, Brown targeted a youthful audience that was receptive to this advice (Brown, The Black Man 341). The poem's straight-forward message taught girls life-lessons about marriage and about important women figures who worked to teach young girls moral lessons.

On the other hand, Brown characterizes Harper as a child to establish her ethos as a teacher. Harper's philosophy on teaching also shares a belief in the inner truths of children. Those who understood that black children could find truth through service and loved could then raise "true men and true women" (Harper, "Our Greatest Want" 160). Brown sees her "in all the simplicity of a child" because he recognizes her abilities in uplifting black Americans. He proclaims also that her poems are "soul-stirring, and all are characterized by chaste language and much thought," (340). To remind his audience that her poetry was "soul-stirring" is to comment on the ways teachers could access the "soul" in their teaching. Mirroring Harper's own thoughts about what black education lacked, it isn’t accidental that Brown uses "soul-stirring” as a descriptor for her poems. Harper's poems embodied her philosophy - they became the agents of the very essence she touted. Tirelessly, Harper lectured to adults and children to bring about change-Brown recognized this as he himself lectured on the anti-slavery circuit. Fulfilling the ideals of an uplifted race required selfless acts and a refined character. Harper embodies the traits she spoke about in her speeches and poetry. Her authority as a lecturer and teacher granted her 
the ability to speak to children. Therefore, Brown's comment should be viewed in the context of the changing cultural ideals of education and not just in the context of gender.

Along with these praises, he adds, "Miss Watkins's advice to her own sex on the selection of a husband should be appreciated by all" (Brown, The Black Man 341). Brown points out the collaborative nature of Harper's poem by suggesting that everyone should heed its lessons on marriage and courtship. More importantly, Paula Garrett and Hollis Robbins remind us that Brown often advocated on behalf of "disenfranchised insiders" which were made up the freed population, educated women, and fugitive slaves. ${ }^{71}$ What Garrett and Robbins neglect to include are the child readers who were familiar with Brown's collection. In fact, black children often read for their families, especially for newly freed slaves. ${ }^{72}$ Considering Brown's editorial choices as accessible to children expands our understanding of The Black Man (1863) because they explain the values that editors wanted to instill in black children in the latter half of the nineteenth century.

The abolitionist circuit continued to circulate Harper's poetry for children after Brown, especially editors such as Lydia Maria Child. The Freedman's Book (1865), one of many of Child's efforts to educate freed people in the south, included six of Harper's works. Among the selected poems, “Thank God for Little Children” (1857) appears directly after Child's essay, "Education of Children." Child herself, an early pioneer of children's literature, published her

${ }^{71}$ See the introduction to The Works of William Wells Brown: Using His 'strong, Manly Voice" vxii-xviii.

${ }^{72}$ See Karen Chandler's "Ye Are Builders" in Who Writes for Black Children? and Beverly Lyon Clark's Kiddie Lit: The Cultural Construction of Children's Literature in America 101. 
collection so that it could be read aloud and "expended [sic] in schools for you [freed people] and your children" (iii). Her intentions were to give the book to the Freedmen's Aid Association for schools for black freed people, however, according to Robert E. Butchart, her book was only available to some black schools in New Berne, North Carolina (126). Nevertheless, in her earlier endeavors to educate children, she advocated for children's agency and encouraged them to be active readers and critics (vii). For example, in 1826, she printed in the Juvenile Miscellany that children should have principles and:

If I can lead you to examine your own hearts...I shall be very happy... if you will persevere; if you will be attentive; if you will learn to think for yourselves; you can overcome all obstacles in the path of knowledge. (iv)

In her collection for freed people, she uses similar tenets of self-reliance to uplift black Americans disenfranchised by slavery. She infuses transcendental ideas in texts for children, which influences the way Harper's poem is read within this context.

The essay that precedes “Thank God for Little Children” provides a window into the same ideology that Harper used when describing the soul of children. Child shares this ideology with freed adults whom she finds responsible for inculcating children (222). Like Harper, in "Education of Children," Child articulates the environmental differences that contribute to the inner beings of the newly freed children and white children. Child refers to children's souls as sacred and in need of nourishment from adults (221). When that environment is not conducive to nourishment, then children's souls become "poisoned” from cursing, swearing, and being "trodden on when they [were] little [and enslaved]" (Child 221-2). She uses the history of enslavement to explain freed children's lack of access to the same spiritual and moral opportunities that their white counterparts enjoy. Harper also subscribed to this ideology and 
believed the way to upward mobility was for each freed person to improve morally. In other words, one must improve the self in order to seek advancement. Therefore, placing the responsibility onto freed adults to train their children to be moral citizens portrayed blacks in a positive light. This is why so much of Child's essay concerns freed adults working to improve their own morality because children mimic what they see. This instruction connects to transcendental ideas where each person is connected to a larger purpose. Through inward reflection and recognition of what humans' larger purposes are, humans, especially children can work for the betterment of society.

Harper's “Thank God for Little Children," nestled between Child's essay, chapter six of Stowe's Uncle Tom's Cabin, and the poem "John Brown and the Colored Child," not only encourages white constructions of purity and innocence, but it shows the humanity of black children. After the Civil War in the U.S., tensions between black and white populations rose as many freed people searched for new lives and employment after slavery. With racial tensions brewing and little opportunities, many freed people remained stunted and impoverished. However, the advent of freedom meant new possibilities for future generations of freed people. Children symbolized new beginnings and stableness as long as they were reared properly. Within this context, Stowe uses sentimentality as a tool for granting black children humanity. Though white adults reserved the constructions of childhood innocence and purity for white children, Stowe repurposes them to give black children constructions of humanness. Stowe used the performativity of childhood innocence to show black readers that they had souls and could be "blossoms" chosen from angels and gifted to adults. Using Harper's poem, Stowe expresses the humanity and preciousness of black child lives. 
As literary aesthetics shifted and black male critics began to shape an African American literary tradition during the early twentieth century, Harper's influence and poetry began to fade from public view. W.E.B. Du Bois dedicated The Brownies' Book (1921-1923) to black families and featured "a new image of and for the black child" (Bishop 34). Du Bois aimed for his family magazine to counter racism, stereotypical images of black children, foster race pride, and promote positive behaviors among black children (Bishop 35). Because Harper's poetry was written during the antebellum and Reconstruction periods in the U.S.; much of her work was not en vogue for the burgeoning tradition fashioned by W.E.B. Du Bois and later Alain Locke. This shift in literary preference is seen in W.E.B. Du Bois's eulogy of Harper in his April 1911 issue of The Crisis where he claims, "She was not a great singer, but she had some sense of song; she was not a great writer, but she wrote much worth reading" (20). After he dismisses the importance of her aesthetic, he claims, "To the young colored American, Frances Harper leaves a lesson. Here is a nation whose soul is still dumb, yet big with feeling, song and story" (Du Bois, "Editorial" 20). Du Bois did not see the importance of Harper's educational poetics to children; he instead saw the importance in the failure of her work - that is, he saw that because Harper's poems did not instill racial pride, it was up to his generation to do so. He believed there was much work to be done to produce more "soul" writers - that is, writers who could produce literature that spoke to the African American experience. Similar to the anxieties Harper and her contemporaries experienced with the education of freed children, Du Bois's anxiety lay in his and his contemporaries' efforts in producing future black writers: "What are we doing to develop writers to express this wealth of emotion fitly?" He responds to his own question, "Very little" (Du Bois, "Editorial" 20). 
What's surprising is that Du Bois does not mention Harper's efforts to educate youth even though both of their philosophies mirror each other. In Souls of Black Folk, Du Bois claims that black higher education should "seek the social regeneration of the Negro, and it must help in the solution of problems of race contact and co-operation" (Du Bois, Souls 108). He goes on to explain that it "must persist and evolve that higher individualism which the centers of culture protect; there must come a loftier respect for the sovereign human soul that seeks to know itself and the world about it" (Du Bois, Souls 108). Harper's speech about black education also touted an introspection of sorts, one that benefitted the morality of children. It seemed, then, that Harper's poetics and speeches were a pioneering force for Du Bois's own educational philosophy. Even his idea of the talented tenth has earlier roots in Harper's Iola Leroy (1892). ${ }^{73}$ But because Harper was a woman and her work was steeped in nineteenth-century sentimental modes of writing, men who shaped early conceptions of the African American literary canon felt her work did not serve the purpose of the canon.

After Du Bois, Alain Locke further relegated Harper's poems to the margins whenever he developed his ideas on black aesthetics. In the introduction to Locke's The New Negro, he proclaims that the problem with race literature is that "the negro has been more of a formula than a human being" (Stewart, The New Negro 3). Lamenting how past black writers had not shaped art but instead reacted to oppression, Locke fashions a new aesthetic for black artists where they have "renewed self-respect and self-dependence" (Stewart, The New Negro 4). The audience to which Locke wrote his manifesto was "to the younger generation" which is placed into the

${ }^{73}$ Iola also believed that it was the responsibility of a well-educated elite class of black Americans to uplift the freed people. 
beginning pages of his collection. Locke fashions this new aesthetic that he proclaimed spoke to a distinct African American literature. As he's doing so, he also acts as a mouthpiece for the youth in his short essay, "Negro Youth Speaks" (Stewart, The New Negro 47). Linking all black experiences together, he envisions a common experience that could speak for all black youth. Because this new aesthetic sought more "authentic" voices that departed from sentimental writing, Harper was left out of the new aesthetic. In fact, many women were; among the contributors of this volume, only three women were mentioned. He envisioned young generations of black writers dismissing sentimental modes of writing.

Along with changing ideas of what African American literature looked like, another dimension to Harper's absence in the canon was the limited publication opportunities for black periodical literature. Even the primary children's periodicals of the nineteenth century did not include Harper's work. The majority of black writers used the black press to publish their works (Gardner). Without a broad circulation, many poems were printed in ephemeral texts. Harper's children's poems remained devalued as publishers sought children's poems from white female authors of the time.

Despite Harper's fading importance in early twentieth-century collections, recovery work from scholars in the late twentieth century helped resurface Harper's educational poetics. Hazel Carby was responsible for the recovery of Harper's work in 1987, especially as it pertained to how Harper used her novel Iola Leroy in service to the race (Carby 71). In 1994, Faith Jaycox edited a collection entitled Ebony Angels (1994), which featured numerous selections as early as Jupiter Hammon to as late as Maya Angelou and Rita Dove. Jaycox explains that she chose selections that: 
Reflect the major themes in African-American writing about angels during the last two hundred years. They have been chosen, in addition, to illustrate the wide variety of authors who have engaged these themes, and the forms in which they have done so. (13)

Though not explicitly stated, the collection is made with a youthful audience in mind - there are illustrations throughout as well as short biographies of each author. Like her predecessors William Wells Brown and Lydia Maria Child, Jaycox places importance on the shapers of this tradition to emphasize the continuity of an African American literary tradition. For example, in the back of the book, she provides brief biographies of prominent black writers who played a large role in shaping the current canon - so did Brown and Child, though they featured biographies alongside the writers' works.

Even though Harper's education poetics were remnants of changing conceptions of childhood, Jaycox repurposes them in her collection to express the continuity of a distinct African-American tradition. Jaycox assembled her collection to educate readers about the importance of literary angels despite the context from which nineteenth-century authors such as Harper were writing. She articulates the importance that religion has played in the African American literary tradition. More particularly, she expresses the importance that literary angels have had both in shaping the African-American literary tradition and in encompassing the spirituality of African heritage (Jaycox 8). However, for Harper, depicting children as angels was more of a nineteenth-century phenomenon where "characterization of children as innocent and untainted by the wordly world of adults was common, and children often were idealized as figures of purity connected to the home and to heaven" (Baxter and Ellis 2). For Jaycox, establishing a tradition of African American writers who also spoke about angels was extremely 
important for her project's framework. Lack of diverse representation in religious depictions fueled Jaycox's purpose; this purpose dissociates the contextual nuances of Harper's children's poems. Even still, Jaycox reappropriates Harper's construction of innocence and applies it to constructions of black childhood to serve an alternative purpose for black children's identities.

Ebony Angels features an edited version of "Thank God for Little Children" that repurposes nineteenth-century symbolisms of children as angels in a multicultural context to reestablish black innocence. Jaycox uses only stanzas one and three, which only refer to children and angels. She deletes the rest of the poem, which details the ways children soothe adults' worries. In the first stanza, the narrator describes the children as "bright flowers" and lifeboats and the angels "drop down the sweet white blossoms [the children]" onto earth in the third stanza (Harper, "Thank God" 55). By editing the poem in this manner, Jaycox excludes adults and changes the meaning of the poem altogether. Her version emphasizes children as heavenly beings and de-emphasizes the services they provide for adults. Considering that Jaycox creates this collection to express representative black writers who write about angels, this change reflects a growing need to represent black children in the same constructions of childhood as white children. That is, she wants society to view black children as innocent, young, and carefree.

A growing need to emphasize black children's youthfulness stems from the ways the U.S. overestimates black children's ages. Take, for instance, in 1989 the Central Park Five boys who were arrested and falsely accused of raping a 28-year old white female jogger. Korey Wise, who was then sixteen, was tried as an adult and convicted of assault, sexual abuse, and riot ("Korey Wise"). He was sentenced to five to fifteen years, but he served 11.5 years after DNA testing confirmed that he and the other four boys were not the rapists. Incarceration of black children, especially black male children is more likely to happen due to stereotypes of racial differences 
and the police overestimating their ages (American Psychological Association). Jaycox redirects attention back to nineteenth-century notions of child angels to reaffirm the innocence of black children.

The edited version, however, reflects twentieth-century constructions of childhood where children do not play an active role in the fight for equality. Harper had hoped children in the nineteenth century could play a large role in creating a just society. Even the Christian Recorder echoed Harper's sentiments in their June 8, 1861 article, "Children in History." 74 In the twentieth century, the idea that children could make apt decisions about their social needs on a larger scale was no longer valid. Though many students played a role in the civil-rights movements and often led boycotts to end under-resourced public schools, their efforts were often overlooked (Anderson, “The Other Student”). Youth activism, though powerful, is still seen as lesser than adult activism because society is unable to see youth as leaders and decision-makers. The autonomy that Harper envisioned for nineteenth-century black youth fell onto deaf ears once twentieth-century constructions of childhood began to serve adults more than children. Rebecca de Schweinitz relates that even Martin Luther King, Jr overlooked the agency of youth during the 1963 Birmingham campaign (239). She explains that he felt it unethical to use children in the fight for equality even though many youth leaders chose to fight for their rights. As youth

\footnotetext{
74 The unnamed contributor states, "We argue the value of children from the place God has given them in the history of our race. A great part have they borne in the annals of the world, as accessories indeed, and yet so as to show that God has bound up their destiny with that of adult mankind" ("Children in History")
} 
activism continues to grow and strengthen in the U.S., the constructions of childhood in the early twentieth century plague how adults see youth as partners in the same fight for equality.

In keeping with the ways twentieth-century constructions of childhood serve adult needs, Jaycox situates "Youth in Heaven," between two poems that speak about the benefits of heaven and of angels. Divorced from its context, this poem takes on new meaning about life in a JudeoChristian heaven. Angels' lives are emphasized over children and the soothing comforts that the after-life brings reflects the purpose of this poem within the anthology. Bracketed by "Singing Hallelujia” by Fenton Johnson and James Mackey’s “Morning: A Prayer," this poem brings comfort to readers who struggle with the discomforting truths of the world. All three poems invite positive readings of angels because narrators either sing about angels welcoming them to heaven or about the protection they provide as guardians. Poems in this sequence make cultural connections with the history of enslavement by introducing melodic, gospel verses that speak about the goodness of rest (death) after traveling through a troubled world. One can read the last three poems of Jaycox's collection as a sojourn through life's experiences. The narrator in Johnson's poem sings about the angels robing him after he repeats the refrain "Take me swift to heaven" (89). Upon the narrator's death, he praises the long-awaited rest he feels once there. "Youth in Heaven" provides imagery for what heaven looked like. It is characterized as a utopia where "the eldest of the angels/ Seems the youngest brother there" (89). Eternal youth symbolizes an ideal that one expects after a long sojourn on earth. This poem explains how a life lived through Christ could invite the comforts of a heavenly afterlife. The collection, however, ends with a prayer and awakening. The narrator in Mackey's poem thanks his heavenly father for keeping him safe with guardian angels. Before the book ends, the narrator awakens to a Monday morning where he is once again kept safe. With these three poems ending the collection, it 
appears Jaycox wanted to remind readers about hope through the afterlife as well as the comfort in knowing that guardian angels protect all.

This collection demonstrates a revival of Harper's religious education for black children because it not only uses "Youth in Heaven" and "Thank God for Little Children," but parts of "Moses A Story of the Nile (1869)." One of Harper's popular poems, "Moses" is a blank verse poem that tells a familiar story about a Moses who led his people from slavery. Harper identified with Moses and wanted to create for people a character who symbolized leadership and service to his race (Foster 136). For Harper, Moses represented service to humankind and courage that stemmed from his religious faith (Foster 136). Because Jaycox wanted to celebrate the religious heritage of African Americans, she too included this story that has many parallels between American enslavement and the Israelites' enslavement. However, Jaycox only prints the last few verses of the poem where Moses dies. The ending is only the beginning and speaks highly of Moses as a man of good faith. Because Harper wanted black Americans to emulate Moses's religious faith, she created this poem during her travels in the South from 1865-1871. For it to be selected in Jaycox's collection means that it carries symbolism for the continuity of African American religious faith, and it promotes a strand of Harper's education poetics. For adults and children alike, emulating Moses even until the day one dies grants one peace in the afterlife. Moses's death, for instance is positive: "With gentle hands they [angels] bore him/ That bright and shining train" ("Moses" 32-3). The angels also “...sang no mournful dirges, / No solemn requiems" ("Moses" 33). Due to its accessibility and narrative style, children could easily read about the figure who represented more than freedom for Israelites; Moses represented someone they could be. 
After Jaycox's collection, Harper is forgotten as a children's poet until Karen Kilcup and Angela Sorby's Over the River and through the Woods (2013). This expansive anthology features an array of poets from the nineteenth century, some of which experimented with the genre. Both editors explain that their thematic approach to this anthology is meant to bring poems into conversation with one another and into larger conversations surrounding transatlantic scholarship, book history, and sentimentalism (Kilcup and Sorby 3). Their attempts to bring awareness to nineteenth-century poetry in general and children's poetry, specifically resonates with modern readers. Without complex contexts framing the way nineteenth-century readers experienced each poem, modern readers have the opportunity to shape their responses to the text based on critical reading. Even the ways the editors bring together black child-authored poetry with white-authored texts yield interesting patterns in each party's reflections of childhood, even though these texts were never meant to share the same space in white-dominated publishing houses. Harper's two poems "The Little Builders" and "Jamie's Puzzle" are both featured in the collection, though under different headings. The editors feature the former poem under the heading "Slavery and Freedom" while they feature the latter poem under "Death and Affliction." Each poem attests to Harper's long career in providing educational poetics for black children.

The editors may have chosen "The Little Builders" because of its reinforced message of anti-slavery and human worth. Kilcup and Sorby pack twenty-five poems neatly within the "Slavery and Freedom" cluster and every one of them are anti-slavery. Each poem emphasizes the human worth of its subjects, which attests to the goals of this section. Though not representative of the types of poetry nineteenth-century children read concerned with slavery, this collection does feature poems that reflect initiatives to teach children their worth and service to the race. For instance, as suggested in its title, "The Little Builders" focuses on telling children 
how they can rebuild a love for freedom. Through love of the "true and right," children can build "the throne of freedom/ On a pedestal of light" ("The Little Builders" 294). This message appeals to historical lessons on slavery while also having a modern message attached. Children who read this poem in the twenty-first century can adhere to its message to "fill [their] minds with useful knowledge" about slavery. It also teaches them about modern-day ideas of truthfulness and kindliness. Whereas uplift and reform was on the minds of nineteenth-century abolitionists, Kilcup and Sorby's agenda is more so to expose a wide range of poetry about slavery and freedom that could be conversant with poetry of the same nature.

"Jamie's Puzzle" which is divorced from its late nineteenth-century context speaks to modern sensibilities of teaching children about death. First published in Harper's 1895 edition of Poems and within the last few years of Harper's life, "Jamie's Puzzle" was an addition to Harper's republished Poems. Within the poem, a child questions the passing of his grandmother and mother. The narrator explains where the deceased go so that the child can understand. After a few lines that reason with the child, the child begins to understand why his mother had to leave as well: "Grandma, he said, must be lonesome/ And mamma has gone to her" (336). He still is puzzled by the fact the he has to be left behind. The poem ends with this question still unanswered and concedes that the answer to these questions will be revealed in heaven. This poem reassures readers about the difficulty in teaching children about death no matter the century.

In modern times, poetry for black children echo similar tenets about self-reliance, morality, and education that Harper's poetics promoted. A simple google search will reveal poetic topics about human worth, religion, and the power of knowledge particularly for black children in an age where their lives continue to be perceived as less valuable than their white 
peers. Without Harper's dedication to racial uplift and a tailored education that benefitted black students, many educational philosophies from black intellectuals such as W.E.B. Du Bois to Booker T. Washington would not be as developed. It took someone in the trenches to understand the need for a tailored education that spoke to the needs of black children and Harper delivered on her promise.

If Harper's reception history has taught us anything, it is that her life's work continues to unfold in front of us as we continue to unroll the forgotten pieces in her oeuvre. Her reception as a children's poet shows that she held a progressive and radical agenda for children's involvement in the anti-slavery movement. Her philosophy for educating black Americans is encompassed in her speeches, letters, and poetry. Piecing these texts together reveals a rich strand of her history that has gone unnoticed for some time. Until recently, scholars have neglected to include Harper in their collections focusing on children's poetry. Though devalued because of her gender and literary aesthetics, Harper's work has persevered, and her poetry reflects the strength she placed into each line. Her tenure as a children's poet leads to investigations of sentimental literature in the black communities and how this literature not only moved its audience, but helped the audience participate in literacy. Sentimental literature helped strengthen anti-slavery causes not only because it was affective, but because it was accessible to illiterate audiences in the nineteenth century. Janet Gray explains, "critical inquiry into race should not render it invisible but should produce knowledge usable in the transformation of oppressive systems" (10). The cross between Children's literature and African American print culture leads to promising studies of what it meant to be literate during the lack of access to public schools. Harper's recovered reception as a children's poet grants access to promising scholarship on the neglected voices in the African American literary canon. 
The Playfulness of Dunbar's Dialect and Standard English Poems in Children's

\section{Literature}

Perhaps Dunbar's greatest triumph is that he has survived all those who would use his gift for their own dead-end purposes.

--Nikki Giovanni ${ }^{75}$

The previous chapter explored the relationship between Frances Harper's poetics and her goals of educating black children. Paul Laurence Dunbar (1872-1906), however, did not speak to children outright in his poetry. Therefore, this chapter analyzes the ways editors appropriated his text into children's literature. Dunbar, most notable for his plantation dialect poems, received his fair share of praise and criticism. From William Dean Howells's praise, albeit demeaning, to 1920s New Negro critics' disdain, the reception of Dunbar's poetry has taken many forms. ${ }^{76}$ Though Dunbar fashioned many poems in standard English, his plantation dialect poems won

${ }^{75}$ See Giovanni's “Afterword” in Jay Martin's edited collection of essays: A Singer in the Dawn: Reinterpretations of Paul Laurence Dunbar (244).

${ }^{76}$ In a June 1896 review of Dunbar's poetry in Harper's Weekly, Howells compares Dunbar to Robert Burns, suggesting that Dunbar's "negro pieces" had more impulse and feeling, similar to Burns" "Scotch" and "peasant" works. Howells continues, "When Burns was least himself he wrote literary English, and Mr. Dunbar writes literary English when he is least himself' (630). Howells showed his limited ideas of African Americans through his review. Howells was not ready to consider African Americans beyond a two-dimensional caricature of minstrelsy. On the flip side, New Negro critics such as Alain Locke, who diminished the value of Dunbar's "sentimental poems" only found value in the poems blatantly depicting protest. See The New Negro: An Interpretation 37-39. 
national and international attention. Deriving inspiration from the Hoosier poet, James Whitcomb Riley (who also wrote children's poetry and endorsed Dunbar), Dunbar crafted dialect poetry to conform to a white market that consumed and redistributed stereotypes of blacks. Despite his later regret of the attention his dialect poems received, especially in the minstrel market, Dunbar continued to write for a white market that accepted and paid for his poetry.

William D. Howells's review shaped the ways later critics and scholars represented the poet. Howells published a review of Dunbar's Majors and Minors in 1896, which brought Dunbar national acclaim. Within the 1896 pages of Harper's Weekly, Howells proclaims, "When [Robert] Burns was least himself he wrote literary English, and Mr. Dunbar writes literary English when he is least himself' (630). Howells intended positive reflections on Dunbar's Majors and Minors; however, he originated an essentialist review. Comparing Dunbar's blackness and humble beginnings to Burns' Scotch and lower-class ranking, Howells initiated a lens that continues to be used. Scholars search for a true representation by analyzing his Standard English poems or mine what the poet says about his subjecthood. This legacy has shaped the ways critics and scholars navigated discourse surrounding Dunbar's choices and career. ${ }^{77}$

Not surprisingly, early twentieth-century scholars worked to discredit Dunbar based on his perceived blackness. As demonstrated in the last chapter, New Negro critics banished works that did not use themes related to blackness. Critics either argued that Dunbar's dialect poetry

77 See Alice Dunbar Moore-Nelson's memorial “Paul Laurence Dunbar: Poet Laureate of the Negro Race." Nelson writes, "it was in the pure English poems that the poet expressed himself. He may have expressed his race in the dialect poems; they were to him the side issues of his work, the overflowing of a life apart from his dearest dreams." 
accommodated racial stereotypes of blacks or they argued it subverted them. ${ }^{78}$ Later twentiethcentury editors of Dunbar's biographies countered scholars who only focused on Dunbar's dialect poetry as a way of understanding the poet. For instance, one editor, Ashley Bryan, felt that just attention had not been paid to the ways Dunbar imagined nature, religion, love, and sadness, which could be found within his Standard English poems. As the century progressed, scholars began associating these themes with his Standard English poems, further suggesting that Dunbar was his genuine self when he wrote in this language. Amanda Mehsima Licato argues that Dunbar created metapoetic standard English poems to escape the identity placed upon him through his dialect verse. Even scholars who discuss Dunbar's georgic poems to reveal his articulation of labor, leisure, and the multiplicity of black experiences do so with the assumption that he is most himself when he speaks about black subjecthood.$^{79}$ These lines of inquiry, though productive, limit the ways we represent Dunbar and his influence.

${ }^{78}$ Scholars such as Henry Louis Gates, Jr. and Marcellus Blount claim that the dialect in Dunbar's poems "signify" on its white audience and therefore subverts Standard English. Cohen and Reynolds J. Scott-Childress have portrayed complex portraits of dialect in American literature.

${ }^{79}$ See Nadia Nurhussein's Rhetorics of Literacy and Benjamin Child's “The Plantation Countermelodies of Dunbar and Du Bois: Writing Agropolitical Subjecthood in the Nadir." In Child's essay specifically pertaining to Dunbar, he articulates the ways the poet imagined legacies of slavery through agropolitics. More particularly, Dunbar's process of prosopopoeia through a tree, soil, and a plantation created a space for ownership of a traumatic past for African Americans. 
Despite what these new lines of inquiry suggest, they only focus on how to represent Dunbar through his blackness and humanness. Looking beyond these modes of identity to the reception of his poetry opens new avenues of understanding. One such avenue is the circulation of his poetry as children's literature. Focusing on his poetry as children's literature reveals an expanded view of Dunbar's poetics and their representations.$^{80}$ In the following pages, I propose that Dunbar provided an uncommon voice in the development of modern childhood in varying periods: from the early twentieth century, Dunbar's poems were used in various white youth publications for entertainment purposes and often created stereotypical representations of black characters for white children to consume and reuse. At the same time, some of Dunbar's Standard English poems were used in black publications (and in some cases, white publications) to teach markers of middle-class status and to help upper class black families achieve similar markers of citizenship as white families. His genteel style of writing promoted an image of

${ }^{80}$ My argument hinges on the fact that we should look beyond Dunbar's intentions. Even though there is a point in history when Dunbar also suggested to his editor, Edward H. Dodd in 1905 that he should produce a photographically illustrated book of lullabies and poetry for children, the plan never came to fruition because Dodd, Mead had already published poems suitable for children in past publications that weren't necessarily solely for children. Besides this fact, the histories of the contexts in which Dunbar's poetry was circulated deserve greater attention. Since many of his poems were excerpted from his collections and into periodicals and magazines, his poetry reveals new stories about the lives that they took after their publications. For information about Dodd and Dunbar's exchange, see Ray Sapirstein's dissertation, Out from behind the Mask. His records are from the Paul Laurence Dunbar Papers from the Ohio Historical Society. 
upward mobility marketable to students advancing in the dangerous Jim Crow era. In the mid-tolate twentieth century, Dunbar's poetry worked in tandem with the Civil Rights Movement and Multiculturalism to provide expanded representations of blackness. From then to the twenty first century, Dunbar remained a central figure in preserving black heritage, even if he was disparaged for this same tradition over 100 years ago. A focus on reception history can teach us the farreaching effects of black poets' lyricism and can supply expanded representations of early black poets.

Dunbar, son of Matilda and Joshua Dunbar was born on June 27, 1872 in Dayton, Ohio. After graduating from high school, he published his first poetry collection, Oak and Ivy, in 1895 after receiving support from James Newton Matthews at the Western Association of Writers and James Whitcomb Riley. In the same year, his second collection, Majors and Minors, was published and gained the national recognition it deserved. Throughout Dunbar's short life (he died at 33), he published twelve poetry books, four books of short stories, five novels, and one play. Forty of his poems were set to music by famous musicians such as Samuel ColeridgeTaylor, a black composer of London, and J. Rosamond Johnson, a prominent black musician who helped compose "Lift Ev'ry Voice and Sing."

Dunbar's poems appeared in a range of periodicals, including children's publications as early as 1901. He was featured in well-known periodicals of his lifetime, including The New York Times and Harper's Weekly. Dunbar's popular poems, especially from his collections Majors and Minors (1895) and Lyrics of a Lowly Life (1896), began circulating in other contexts for youth. His Lyrics was rebound and published with a Presbyterian youth organization's name 
listed on the title page and was also housed in its library.$^{81}$ His dialect and Standard English poems appear in anthologies for schools in the early twentieth century, and several children's biographies of the poet appeared in the latter half of the twentieth century. ${ }^{82}$

\section{The Children's Market and Dunbar's Poems}

During the time Dunbar published his poetry collections, the children's market expanded dramatically (Kilcup and Sorby 7). After the Civil War, a firmly established middle-class sought distinctive class markers. In addition to material possessions, middle-class citizens had access to leisure, and it became a defining feature of that status. To have leisure meant that middle-class families had more time for reading, and thus, recitations of poetry became an important signifier of class status and education. Along with an expanding social class came expanding social functions of poetry and its uses. Kilcup and Sorby relate that "emerging social forces pushed children's poetry in new directions: if children still learned what to feel, they also learned how to behave socially, what to play, what to buy, and even how to be naughty within acceptable bounds (7). Thus, the professionalization of children's poetry led to a wider distribution of poetry meant for socializing children toward expected norms. Influential children's magazines such as St. Nicholas, Our Young Folks, Harper's Young People, and Youth's Companion contributed to a

\footnotetext{
${ }^{81}$ For the website, see Between the Covers. See following citation for bibliographic information:
} Dunbar, Paul Laurence. Lyrics of Lowly Life. New York: Young People's Missionary Movement of the United States and Canada (Variant Issue), 1896. Print.

${ }^{82}$ Not only were Dunbar's poems circulating in children's magazines, his short stories were too. In 1900, the influential Youth's Companion circulated his fiction piece, "Old Abe's Conversion" under the heading, "Stories for the Family." 
sentimental education for children in the latter half of the nineteenth century. Of the four, Dunbar received mentions in St. Nicholas and Youth's Companion for his dialect poems and short story. ${ }^{83}$

Not only was Dunbar's poetry mentioned in popular children's magazines, it was featured in publications meant for black and white families alike. Dunbar's appearance in contexts outside of popular children's newspapers and magazines suggest that we take a broader view of what constituted children's literature and its influences. These contexts blur the lines between adult and juvenile poetry in many of the ways the poetry of the Schoolroom poetsLongfellow, Whittier, and Bryant $-\operatorname{did} .{ }^{84}$ Dunbar's reception in contexts outside of prescribed children's magazines causes us to pause and reconsider the dimensions of his poetry that influenced not only adults, but children.

In November 1901, Mary Mapes Dodge acknowledged Dunbar's dialect verse in her children's magazine, St. Nicholas. Within this particular issue, Dodge mentions Dunbar's “Three Humorous Negro Poems," which were placed in the November issue of Century alongside Mark

${ }^{83}$ See the 1901, Volume 75 issue of Youth's Companion under the heading "Stories for All the Family." The editors list Dunbar's novel, Old Abe's Conversion. For St. Nicholas, see the November 1901 issue. The editors state that the November Century magazine featured "Three Humorous Negro Poems, By Paul Laurence Dunbar" (14). Though not detailed in this issue, the three dialect poems were: "A Virginia Reel;" "The Suitor;" and "Noddin' By De Fire." ${ }^{84}$ See Longfellow's “Paul Revere's Ride," which was first published in Atlantic Monthly, but became a schoolroom recitation-piece (Kilcup and Sorby 4). 
Twain's short stories, "Two Little Tales." ${ }^{85}$ By this time, The Century Company had purchased St. Nicholas from Scribner's and changed the magazine's name to St. Nicholas: An Illustrated Magazine for Young Folks (Mott 468). The company also purchased Scribner's Monthly and changed it to Century Magazine (Mott 468). Notably, Dodge listed the selections as poems, which showed their importance. According to Angela Sorby:

St. Nicholas relied on compartmentalization and hierarchy to educate children's tastes. The table of contents developed a three-tier system for poetry, in which pieces were classed as either 'poems' (important valuable, virtuous), 'verses' (less important, less valuable, less virtuous), or 'jingles' (not important, not valuable, not virtuous) (72).

${ }^{85}$ The first story from Mark Twain was entitled, "The Man with a Message for the DirectorGeneral" and the second was "How the Chimney-Sweep Got the Ear of the Emperor." Both stories feature ridiculous plots meant for humor and entertaining young readers. Especially notable is the second story, which features a young chimney sweeper named Jimmy whose plot to heal the ill emperor involved getting him to eat watermelon. Jimmy, as the narrator tells readers, heard the remedy from "that old gray-headed Zulu," who is pictured in the magazine as an older, black minstrel caricature who is seated half-naked with watermelons surrounding him (Twain 29). Of course, the plot works and the emperor rewards Jimmy and the Zulu character with boots. Jimmy, who we assume to be white, is also pictured as a minstrel character. After his chimney sweeping work, he appears "blacker than any other object imaginable, and he had his brushes on his shoulder and his soot-bag at his waist, and no feature of his sable face was distinguishable except his lively eyes" (Twain 26). 
Near Dunbar's acknowledgment appears in bold face "short stories by Mark Twain.” Dodge attracted young readers to more familiar authors for children like Twain, who published Tom Sawyer and Huck Finn a few decades prior to these stories. Mentioning Dunbar in the same space as Twain, who also wrote "painstakingly" in dialect, brought a different type of celebrity to his poems. Dunbar's dialect poetry functioned as entertainment for children, even if the market had not yet established age-appropriate literature. ${ }^{86}$ Though Dunbar's poems are not included in the actual issue, Dodge's gesture toward their use value for children is significant. St. Nicholas, a prominent and influential children's magazine, notable for its humorous moral and educational pieces, features "jingle[s] in a broken tongue," or dialect language, that is meant to represent humorous scenes of plantation life. ${ }^{87}$ Why did Dodge mention these verses to children? A glance at the historical context associated with these three poems reveals how Dunbar became appropriated as a children's poet for black and white audiences. Their placement in this context also shows how Dunbar's dialect poetry educated black and white children.

Beginning in the late nineteenth century, or during the nadir (1877-1914) of black cultural history, most white audiences favored Dunbar's dialect poems because of their familiar associations with minstrelsy. From banjos to Sambo-like characters on southern plantations, many of Dunbar's dialect poems reinforced stereotypes on which the minstrel market thrived. The folk voice that emerged from Dunbar's poems attracted the attention of editors of children's literature because of its close association with child speech, according to Katherine Capshaw Smith (115). Though many editors worked to rectify child speech through the circulation of

\footnotetext{
${ }^{86}$ See the "Explanatory" note before Huck Finn for Twain's thoughts on writing in dialect.

${ }^{87}$ Dunbar describes his dialect verse as "a jingle in a broken tongue" in his poem, "The Poet."
} 
standard English poems, they continued to circulate Dunbar's dialect poems. Dunbar's popularity in these magazines and newspapers stems from the ways Howells characterized his poetry. Smith further explains the consequence of Howells' 1896 review: "By denying even the label 'dialect' for Dunbar's poems, Howells excludes the black writer from participation in white literary categories and fashions..." (115). Ultimately, Smith argues, Howells and the white literary market reduced Dunbar's work to "child-talk" for the pleasure of white readers (115).

Not only was Dunbar's dialect poetry popular with white editors because of its use of "child talk," his poetry also harbored what Robin Bernstein deems cultural memory. Dunbar's dialect poems entertained memories of the plantation tradition that adults easily appropriated for child audiences. These poems were relics of a past; when appropriated for white children, they became a means of indoctrinating them. White childhood in the nineteenth century was constructed to maintain the invisibility of whiteness and its privileges (Bernstein 7). White adults used Dunbar's poems in children's publications to assert a revised shared antebellum past while maintaining an obliviousness to its racist history (minstrelsy). In other words, white children could acknowledge a dialect poem as part of their educational upbringing without having to acknowledge its role in the oppression of non-whites. This explained why the editor featured "A Virginia Reel," “The Suitor,” and “Noddin' By De Fire” in Century. In a sense, Dunbar's dialect poems became an essential part of education for white youth. The ability to converse with their peers about blackness as seen in these poems offers social standing for white youth. White children who recited and rehearsed this popular art form became acculturated into white American society, thus making black stereotypes of the plantation comfortable and accessible.

On the other hand, black editors who used Dunbar's dialect and Standard English poems for black children did so under the impression that it improved their social standing. Katherine 
Capshaw Smith explains that New Negro scholars appropriated Dunbar's Standard English poems in the classroom. They appropriated Dunbar as a symbol of success for black students and used his "hero" poems in black classrooms. New Negro scholars used poems such as "Black Samson of Brandywine" as a way of "celebrat[ing] black breakthroughs in American culture" (Smith 119). Dunbar's celebrity propelled their philosophy of creating black distinctiveness in a time where it was overshadowed by white literary critics. Despite their feelings towards Dunbar's dialect poems, which many felt were antithetical to their philosophy of the New Negro, they used Dunbar as an example of African American contributions to American literature. ${ }^{88}$ While Smith uses New Negro critics' autobiographies and prefaces to explain how Dunbar's poetry was used in the classroom in the 1920s, she neglects to mention Alice Moore Dunbar-Nelson's The Dunbar Speaker and Entertainer (1920). Smith explains that minstrel associations, Howells's characterization, and Dunbar's own interest in childhood as a subject lead to his appropriation into black children's literature in the 1920s (115). While disregarding his dialect poems, Smith explains, "as part of their investment in standard English, teachers often turned their students' attention toward Dunbar's 'traditional' poetry rather than his dialect work" (118). Despite New Negro critics' assessments of the field, Dunbar-Nelson challenged their views using this collection. Dunbar-Nelson created the collection not only to combat the negative criticism Dunbar received from the era, but to teach children affective recitation. The reader includes several of Dunbar's dialect poems. Dunbar-Nelson explains in the introduction that the volume is dedicated to black children who are not used to hearing about black achievements and

${ }^{88}$ James Weldon Johnson in his autobiography calls Dunbar "impulsive as a child" quoted from Katherine Capshaw Smith 116. 
excellence. This sentiment is not unusual for its time considering many collections before it also touted similar claims ${ }^{89}$ However, what is unusual are the older generations of authors printed in this text. This simple act challenges the narrative that dialect poems were not taught to black children in the classroom in the 1920s, and therefore raises questions about the value of dialect poems for black children in the era of the New Negro. This reader points to the ways Dunbar's dialect poetry continued to be favored and disentangled from its complicated past.

\section{Dunbar's Dialect and Standard English poetry in Religious Newspapers}

Dunbar's appearance in white Presbyterian and black Methodist newspapers even when his poetry did not adhere to specific religious themes, shows the breadth of his popularity. Dunbar's Lyrics of a Lowly Life was used in a white religious context possibly around 1908. His appearance in a black religious publication, on the other hand, suggests a concern with training youth and adults to adhere to growing middle-class status markers. One major concern of black newspapers around the early twentieth century was to train youth to be accepted members in U.S. society, whereas white religious papers were more concerned about their youths' moral practices. Religious newspapers that circulated Dunbar's poetry provide a window into the growing concern for youths' (and parents') participation in a divided United States.

In 1898, the Home Mission Monthly, a Presbyterian periodical, mentions Dunbar in its "Young People's Department" (M.K.J). In this short article, the writer mentions that the topic for the April Home Missionary meeting will embrace "the resources of the Freedmen, their perils, and the encouragements in the work" (M.K.J). The writer notes Dunbar, along with Frederick Douglass, Booker T. Washington, and the President of Biddle University, Dr. Saunders, as

\footnotetext{
${ }^{89}$ See The Freedmen's Book, The Black Man, and nineteenth-century black edited newspapers.
} 
having "strong mental power, combined with executive ability, discretion, and unwavering fidelity to duty" (M.K.J.). Drawing from popular, great black men, the magazine encourages its youthful readers to take seriously "the progress made by the negroes" (M.K.J.) The writer encourages his readers to write to the Freedmen's Department in Pittsburgh, PA to obtain closely aligned historical material for the meeting. This magazine recognizes that black history is American history and fights for social justice. Similar to antebellum children's magazines, the Young People's Department Home Mission Monthly highlights achievements of black men to reinforce black people's influence and capabilities in the U.S..$^{90}$ The writer supports the notion that white youth should be concerned about their counterparts. Their moral improvement, based on this argument, rests on the improvement of the underserved.

Dunbar's Lyrics of a Lowly Life, the second collection of poetry which was massmarketed and featured Howells' review, was used in religious contexts for Presbyterian youth. Another Presbyterian mission society harbored Dunbar's Lyrics of a Lowly Life in its library, which suggests the organization used Dunbar's work to form creative interpretations of traditional topics. A rare 1896 edition of the collection includes a variant issue with a Mission Education Movement Library bookplate on the front of the pastedown (Between the Covers). The Young People's Missionary Movement of the United States and Canada is listed on the title page of the edition as well as "Mission Study Reference Library" stamped on the spine. The rare book collector mentions that the issue was bound differently than the first edition printed by Dodd, Mead, which suggests that the Young People's Missionary Movement re-bound a first edition

\footnotetext{
${ }^{90}$ See chapters one and two of this document.
} 
book for study in their classrooms sometime between 1896-1908. ${ }^{91}$ There are not many resources that describe the contents of the Reference Library. However, in an April 29, 1905 issue of The Epworth Herald, the article contains a write-up of the Mission Study Reference Library. The library features "suitable books of reference available for the use of classes and individuals studying the textbooks of the Forward Mission Study Series" (16). The organization's page mentions that on July 18, 1902, they formed their organization at Silver Bay, New York (Presbyterian Historical Society, "Biographical Note"). Their mission was to provide missionary education in the U.S. and Canada, publish missionary education materials, and hold training schools and conferences.

The library housed Dunbar's work so that missionary youth could reference black life. For instance, a nascent white youth group could only spread the gospel if they could convince non-believers to listen. Dunbar's poetry collection gave them creative agency not only to interpret traditional topics anew, but to appeal to blacks in a tongue that was supposedly representative of a culture from which they were only a couple generations removed. The collection featured dialect and Standard English poetry that was pre-packaged for white youth to rehearse. In order to appeal to people who did not look like them, these youth had to be aware of a culture different from their own. Not only was the collection a useful source of prescribed

${ }^{91}$ The organization was formed on July 18, 1902. In 1911, it became the Missionary Education Movement of the United States and Canada (Presbyterian Historical Society). In Mary Helm's The Upward Path: The Evolution of a Race an edition is said to have been printed by Dodd, Mead in 1908 and sold for $\$ 1.50$ presumably by the Missionary Education Movement. 
stereotypes of blacks, it was an entertaining one for white youth. Dunbar's poetry provided a worldview (even if limiting) of black Americans that could be packaged for white Americans.

Dunbar's influence spread to upper-class African American Christian magazines that promoted the same middle-class values as white-authored children's magazines. In 1907, Dunbar's poem, “The Sun” appeared in an African American Methodist Episcopal newspaper entitled Northwestern Christian Advocate..$^{92}$ Editor David D. Thompson selected "The Sun" in volume 55 on July 31 . He placed the poem in a section labeled "The Family" (Thompson 17). Appearing first among advice columns, short anecdotes, and lessons for training children, Dunbar's poem helped families question the "themes" of life. The poem catalogues events related to love and death, while keeping a nice balance between joy and strife. The simplicity of the rhyme scheme of the couplets makes the poem seem as though life can be summed up just as easily — as either love or death. For instance, the following lines illustrate this simplicity:

A little dreaming by the way,

A little toiling by the day.

A little pain, a little strife,

A little joy - and that is life. (Dunbar, "The Sun” 17)

However, the last lines of the last stanza jars readers while begging the question, "But is that all?" (17). Situated in this context, the poem initiates the type of questioning that the editor urges parents to do in their daily lives. Based on the contents on the page, the message suggests that

92 The Northwestern Christian Advocate was a weekly periodical published for the Methodist Episcopal Church. It was published by the Western Methodist Book Concern in Chicago, IL. See July 24, 1907 vol. 55. 
adults should re-think traditional axioms, especially in the realm of raising children. Thompson showed great awareness over discourses surrounding child development. He placed the poem amidst advice pieces related to child play, toys, and family vacation. Within this and other issues, the editor includes poetry by and for children as well as information about child labor that informs adults about children's issues. He inspires parents to participate in ongoing developments of constructions of childhood. Dunbar's poem added complexity to the discourse and helped adults imagine new ways of shaping children toward a middle-class status in the nascent twentieth century.

The decades between 1907 to 1930 saw the least amount of reprinting of Dunbar's poems due to the fading popularity of the plantation dialect tradition. American poetry became more experimental, as modern poets such as Ezra Pound and T.S. Eliot rejected many traditional poetic forms that made Dunbar's poetry popular in the late nineteenth century. After 1908, the Presbyterian Youth Movement published less and eventually discontinued publications until 1969 (Open Library). For the black press, however, a growing need for black editors to shape a literary tradition emerged. However, a split occurred between editors - New Negro critics disregarded most of Dunbar's planation dialect (and Standard English) poems in favor of poetry that refashioned a respected black southern heritage, while editors concerned with establishing a wholistic African American literary tradition accepted Dunbar's poetry.

No longer the popular dialect poet, Dunbar faded into obscurity as New Negro Critics sought poetry that defined what black poetry and literature should be-mostly protest and defining what blackness was. Dunbar's poetry did not fit the "New Negro" philosophy. Besides his unpopular poetry in African American texts, the plantation dialect tradition faded from popularity as African Americans fought against negative representations of themselves. 
Likewise, the mass exodus to northern cities where many blacks sought to distinguish themselves from their southern rural pasts further lessened the value of Dunbar's most famous poems.

\section{Dunbar in Black-Centered edited collections During the 1920s and 1930s}

To combat New Negro Critics who devalued Dunbar's dialect poetry and contested his place in the American literary tradition during the early twentieth century, Alice Moore DunbarNelson, Dunbar's wife, published The Dunbar Speaker and Entertainer (1920) for black students. The first of its kind, the reader contains many selections from black authors and some from white authors (marked by an asterisk in the table of contents) such as John Greenleaf Whittier, Walt Whitman, Phoebe Carey, and a few more. The reader constitutes an invitation to young audiences to appreciate the contributions of blacks to American literary traditions. In the foreword to the collection, Leslie Pinckney Hill, the principal of the HBCU Cheyney School for Teachers, reveals his anxiety over the education of future generations of black students:

Colored boys and girls have not been reading about heroic black warriors and statesmen, martyrs, or saints, though the progress of the world has depended largely upon these. They have not stored their minds with the poetry that has sung its way out of the black man's sorrow and travail and made a place for itself among the lasting monuments of the world's music. (Hill 11)

Hill sees the reader as an opportunity for "self-reliance and race pride" for "dark complexioned people everywhere" (Hill 13). With the endorsement from a prominent member of an HBCU, Nelson was able to influence the ways black students received Dunbar and other poets.

While white publications featured dialect poems to serve racist ends, Dunbar-Nelson divided the texts into several categories, some even included Dunbar's dialect poems. However, Dunbar-Nelson's publication featured a Standard English poem in a category titled "Juvenile." 
She placed Dunbar's “The Seedling” alongside Frances E.W. Harper's “The Sparrow's Fall” in this section. Possibly, she did not include his dialect poems in this section because they do not directly address children like "The Seedling" does. Additionally, when read side-by-side both poems work with the themes of self-reliance and equality. Nelson's goal was to teach young black children the value of these themes so that they could become productive citizens in the U.S.

In the 1930s, editors circulated Dunbar's poetry in their anthologies meant for students, despite the negative reputation his poetry had received from New Negro critics. By this time, New Negro critics had refashioned Dunbar as a representative of distinctive black folkways and black life. New Negro Critics, such as Alain Locke, condemned Dunbar's stereotypical depictions of blacks and felt he did a disservice to all blacks. However, the editors of Readings from Negro Authors (1931) sought to neutralize that reputation by challenging the very notion that there even was a distinctive blackness in the literary form Dunbar used. In the anthology, seven of Dunbar's poems are featured just after Phillis Wheatley's. The huge gap (almost two centuries) between Wheatley and Dunbar means the anthology omits poetry from George Moses Horton and Frances Harper, whose posthumous poetry also appeared in student-oriented publications. ${ }^{93}$

${ }^{93}$ For Horton, see my discussion of his poems' inclusion in Lydia Maria Child's The Freedmen's Book (1865) and Newman Ivey White and Walter Clinton Jackson's 1924 anthology. For Harper, see my discussion of her poems in several black newspapers and collections meant for educating youth, as well as white-authored collections such as Over the River and Through the Woods (2013). 
Within this context, Dunbar's Standard English and dialect poetry became tools for students to learn "universal" principles of poetry. In the introduction, the editors relate that thought, emotion, imagination, and rhythmic language form "essential qualities of the art [of poetry]" (3). Taking cues from Romantic English poets Wordsworth and Shelley, the didactic nature of Matthew Arnold's poetry, Poe's The Poetic Principle, and Amy Lowell's Tendencies in Modern American Poetry (1917), they envisioned how black poetry fits within these standards. Their anthology was intended for classroom study or supplementary reading and they argued that "Negro literature demands no unique method of approach, no special interpretation of the rules of craftsmanship, because the standards of literary form are based upon universal principles" (iii). These editors do not see Dunbar's lyrical poetry as distinct from white-authored poetry, despite Howells's 1896 review. Instead reading black poetry helped students understand the same principles of universality that were taught to white students. They also hoped poetry helped students find joy in reading, much like late nineteenth-century children's magazine editors hoped it would.$^{94}$ Until the late 1960s, Dunbar's reputation rested on similar interpretations of his poetry. Of the seven poems, "Two Little Boots" and "A Negro Love Song" became the most popular of Dunbar's poems for children's publications..$^{95}$

\footnotetext{
${ }^{94}$ For a discussion of editors, such as Mary Mapes Dodge who sought to make their magazines more appealing and less boring to children, see Angela Sorby's “A Visit from St. Nicholas: Pedagogy, Power, and Print Culture" in Schoolroom Poets.

${ }^{95}$ Featured poems include: “Day," “Two Little Boots," “Dreamin' Town," “A Negro Love Song," "The Poet," "Life," and "Ships That Pass in the Night"
} 


\section{The Nineteenth-Century's Influence on Twentieth-Century Dunbar Biographies for}

\section{Children}

In children's literature, Dunbar's poetry offered lessons for children that were both humorous and educational. Before the 1940s, Dunbar's life and works proliferated (Smith 109). Schools, literary societies, and housing settlements were naming themselves after the poet and many biographies flourished after 1940 (Smith 109). By this time, Dodd, Mead — the same company that originally published Lyrics - published Little Brown Baby (1940), a collection of poems “for young people," edited by Bertha Rodgers and illustrated by Erick Berry. Though lacking the lullabies, this collection realized Dunbar's desire to create a text for children. Rodgers' introduction paints Dunbar in a positive light, offering a rags-to-riches narrative about a young black child whose love of poetry at seven years old helped him to gain an elite status later in life. This story made Dunbar inspirational and accessible to a generation more than three decades removed from the poet. Smith explains that the reason for the surgency in Dunbar's popularity was due to the ways artists manipulated his image and poetry. Smith adds, "Dunbar biographers incorporated him into the dominant ideology of racial uplift, offering the poet as a model of literary, material, and social accomplishment within a white world" (109). The biography placed emphasis on Dunbar's love of poetry and learning. Like Smith explains, Dunbar's success story was appropriated as early as the 1920 s in the classroom as a way to emphasize education and black distinctiveness. Rodgers' biography mimicked the same sentiments that Otella Cromwell, Lorenzo Turner, and Eva Dykes instilled in their readers. They wanted students to love reading, no matter the race of the author, which they believed offered universal values. 
Besides wanting readers to understand universal values, Rodgers recycled Howells’ problematic review of Dunbar's dialect poems. By recycling this problematic review, Rodgers signaled to her audience that Dunbar's reputation relied upon the ways his poetry spoke to proeducation and pro-blackness. Rodgers added the sentiments Howells expressed about Dunbar's dialect poetry, suggesting that his dialect verse "would most distinguish him, now and hereafter" (xii). Rodgers used these lines to show how much "Dunbar loved his own people" because his dialect verses express how "his own people” felt (xii). Dunbar's early nineteenth-century reputation returns as he was framed as the poet who conserves "the thoughts of a race, expressed in his own way" (Rodgers xii). This reputation was Dunbar's redeeming factor and it carried with it a host of scholarship that spoke to the ways Dunbar captured an imagined black consciousness. Editors of children's collections later repackaged Dunbar's poems with this reputation to instruct children about an imagined and connected history that favored an appreciation of one's culture and education over an appreciation of Dunbar's poetic style. By focusing less on Dunbar's dialect style, children's editors could by-pass its messy and complex racist past, while offering a diluted version of a poet who could be inspirational to children.

By the late 1950s, authors such as Jean Gould constructed a biography for Dunbar that borrowed from nineteenth-century poetry's use-value (tools for sentimental education) to fashion a new wave of childhood development that focused on Dunbar as an exemplary student. In 1958, Gould published a biography, That Dunbar Boy, which won the Thomas Alva Edison Foundation Children's Book Award for “its special excellence in contributing to the character development of children" (Gould, dust jacket). Gould sprinkles Dunbar's poems throughout the biography, focusing on his love of education. For instance, Dunbar tells his friends that he has aspirations to go to Harvard and his friends and mother, Matilda, constantly encourage him. 
Though Gould's Dunbar makes minor mistakes and pays for them, as evidenced in the poem "A Grievance," she praises his decisions. In fact, Gould glosses over Dunbar's failures as an elevator boy or during his time in London. To construct Dunbar as an accommodationist, Gould needed to by-pass the complexity that came with writing while black in the late nineteenth century.

In one scene, we see the clash between Gould's goals and Dunbar's life. Gould altogether dismisses the minstrel shows in which Dunbar had to write for. After seeing a minstrel show, Dunbar and his friends chat about creating their own show: "'If you ask me, we could put on a better show than that,' Paul said" (68). Randy, Paul's friend answers him in a pseudo plantation dialect: “'Jes what yo' mean, Mr. Interlocutah?"” All of the boys laugh, including Dunbar and he later suggests that they put on a "regular play" (68). Gould side-steps the seriousness of the situation by having Dunbar participate in a culture that demeans his humanity. Gould's Dunbar accommodated racist stereotypes, while he maintained a love for education. Perhaps Gould's optimism stemmed from positive morale of U.S. citizens in the years known as the economic boom in U.S. history. Generally speaking, after the wars, the U.S. experienced economic growth and unemployment rates were low. The middle class had more money to spend and invested in homes in suburban neighborhoods. Progress seemed obtainable and Dunbar's story exemplified the U.S.'s own rise to power. However, segregation accompanied this growth, which hindered many blacks and people of color from making the same progress as whites. Hiding the racist history of Dunbar's dialect poetry reinforced the myth that all students, even black students, could obtain the same success as whites. 


\section{Dunbar, The Preserver of Black Tradition (1960s and 1970s)}

The Civil Rights and women's movements of the 1960s and 1970s changed the dynamics of children's literature. African Americans and women pushed for first-class citizenship which positively affected children's lives. Publishers began publishing more age-appropriate literature as childhood became stratified. Adults strove to protect children from the adult world and took steps to implement topics in their literature that they enjoyed. Dunbar's poetry continued to speak to and for many African Americans, though now his poetry blended with the initiatives of both movements. Critics and children's authors from the 1960s onward continued to consider Dunbar as a preserver of positive black cultural traditions and a symbol of black upward mobility.

In the latter half of the twentieth century, editors of Dunbar's collections sought to affirm his status as a family poet and preserver of African American tradition. In 1963, Charlemae Hill Rollins compiled Christmas gif': An Anthology of Christmas Poems, Songs, and Stories. Rollins, a noted children's librarian in Chicago, sought to preserve the tradition of "Christmas Gif" which harkens back to a game played by enslaved people on Christmas Day. ${ }^{96}$ Rollins explains the game:

${ }^{96}$ Charlemae Rollins was a prominent children's librarian who worked at the Chicago Public Library for 36 years. She promoted positive representations of African Americans and published works that argued for the inclusion of non-stereotypical black characters in children's literature. She published books for adults as well as children, promoting her cause. She had a personal friendship with Langston Hughes, who inspired her to write Black Troubadour: Langston Hughes (1970). She received several awards by the American Library Association as well as 
Two people, meeting for the first time that day, would compete to be the first to call out 'Christmas Gif'!' The loser happily paid a forfeit of a simple presentmaybe a Christmas tea cake or a handful of nuts. (Rollins xvii)

Rollins thought back to the days when her grandmother, who had been enslaved, told her stories about the plantation and the joy they took in what few gifts that they had. Because such little work had been done to record these cultural traditions, Rollins had little material in the library to work with when asked by children for Christmas stories and poems related to black people. Rollins explains that her book is the first to compile this information and is meant for "people of all ages" and "for families to read together" (xvii). Her purpose is to show African American contributions to a celebrated holiday and to familiarize children with a tradition of their ancestors. Dunbar's poems do it justice as most of his Christmas poems preserve humorous reflections on the holiday with imagined characters and plantation spaces.

Rollins includes four of Dunbar's Christmas poems: "Christmas Is A-Comin,"' "Speakin' O' Christmas," "Christmas Carol," and "A Little Christmas Basket." All four poems represent cultural traditions of enslaved people and three are spoken in plantation dialect. Rollins set out to illustrate African American customs; Dunbar's reputation as a preserver of African American heritage proved useful to the collection. Each poem describes Christmas events from enslaved peoples' perspectives, or it describes Christmas traditions. Rollins's anthology is reminiscent of nineteenth century editors' goals of preserving collected works of African Americans to prove their intellectual output and capabilities. For Rollins, she wanted to preserve black heritage and

other associations devoted toward teaching children. For more information on Rollins' life, see Encyclopedia of African-American Writing (2nd Edition). 
to show the contributions of blacks in American culture. In the 1960s, the Civil Rights movement was in full swing, and many sought African American forms and histories that spoke to the proud history of a race. The goal was to reach back in time to understand the station of African Americans at that present moment. Dunbar fulfilled this, even if he was once castigated as an accommodationist of unfair representations of enslaved people. As an exemplar of the preservation of black southern customs, Dunbar's poetry served Rollins' aims. His inclusion shows just how much tastes and values were changing even in the decade of James Brown's famous song, “Say it Loud, I'm black and I'm proud!” Reaching back in time to Dunbar's dialect poetry to show the value of history, librarians such as Rollins sought any expression of blackness. Dunbar's reputation as a preserver of African American culture mattered more than the dialect poems he wrote for the minstrel market. People saw Dunbar's work as positive, rather than as a blight on history. His poetry spoke to the goals of inclusivity, which began to ring throughout the literary, social, and political scenes in America.

After the Civil Rights and Women's Movements of the 1960s, children's books added more complexity to his history than books in previous years did. According to Smith, Dunbar's reputation had flourished because New Negro critics "revised pejorative constructions of black southern character and slave history (110). However, many could not disassociate Dunbar's ties to the minstrel market. In 1975, Jay Martin published A Singer in the Dawn: Reinterpretations of Paul Laurence Dunbar a little more than a couple of years after the centenary of Dunbar's birth. Martin explained one of the objectives for the publication was to reevaluate Dunbar's reputation. In fact, the volume proved important and influenced reevaluations of Dunbar's work thereafter. One of the main contributors, J. Saunders Redding, argued in "Portrait Against Background," "Dunbar labored harder on and put more of himself into his standard English poems than those in 
dialect" (43). Redding's mostly positive review of Dunbar's Standard English poems set the stage for Ashley Bryan's collection, which emphasized how to represent Dunbar through his Standard English poems.

In 1978, Ashley Bryan dedicated a collection to Dunbar entitled, I Greet the Dawn: Poems by Paul Laurence Dunbar. Bryan explains that the collection is "designed to introduce [Dunbar's] work to young people" (18). Bryan characterized Dunbar based on his work in Standard English. He continues: "it is time we saw the whole of Dunbar" (Bryan, dust jacket). Bryan stresses that he "made this selection of poems in standard English, with only a few dialect poems (Bryan, dust jacket). He even includes a quote from Alice Moore Dunbar-Nelson's essay that she published after Dunbar's death to prove his point: "Say what you will, or what Mr. Howells will, about the 'feeling the Negro life esthetically, and expressing it lyrically,' it was in the pure English poems that the poet expressed himself' (qtd. in Bryan 19). Bryan counters a narrow representation of Dunbar by including more of his standard English poems to lead children "to discoveries that take into account more of his poems in the language in which he thought" (19). Bryan adds that this language reflected his natural way of speaking and raises concerns about editors who select only from poems that marginalize the genius of the poet.

Bryan finds Dunbar's Standard English poems worthy of study and not derivative of Romantic English poetry. He argued that young readers could learn about love, life, aging, God, and Dunbar's intent from his standard English poems. In an example, he bookends "The Poet" near the end of his collection. The ending lines reiterate his views:

He sang of love when earth was young, And Love, itself, was in his lays. But ah, the world, it turned to praise 
A jingle in a broken tongue. (163)

For him, Dunbar's expression was most “natural” when spoken in Standard English. Like Howells and the New Negro Critics, Bryan showed an obsession with finding Dunbar's truest self. He even claims that his book allows readers to see Dunbar "as a black human being" (Dust Jacket). The implication is that Standard English will always be valued over plantation dialect writing, even though both are constructions. Bryan's representation of Dunbar is not complete. Instead, it encourages his readers to value Standard English over other constructions of language, which falsely objectifies Standard English. In the decades to come, editors continued to ponder on what to do with Dunbar's dialect verse.

Patricia C. McKissack presents an antithetical approach to Bryan's anthology by implementing similar tactics as Gould, while proving Dunbar's status as an emblem of African American heritage. In this biography, she features popular poems found in other twentieth century collections for children such as "Little Brown Baby," “Ode to Ethiopia," "A Banjo Song,” and twenty-first century favorites, "The Haunted Oak," “A Negro Love Song,” and "Sympathy." Not afraid to talk about death, racism, and lynching, McKissack gave context for “The Haunted Oak." The narrator begins by speaking to young readers about the time Dunbar heard about a lynching in Washington. She summarizes Jim Crow era lynching and shows how Dunbar contributed his opinion on the detrimental acts through his verse. Doing so reinforces themes of social justice to young readers. McKissack's Dunbar addresses racial violence directly and diverges from the former collections that avoid problematic encounters with race and violence.

Additionally, she distinguishes her biography by including contextual discourse surrounding Dunbar's legacy. For instance, she explains that people debated the merits of his 
writing ever since he released his first dialect poem (10). Despite this, "for generations young readers have been discovering 'Little Brown Baby,' 'An Ante-bellum Sermon,' and 'The Party' (121). Indeed, while adults debated the value of his poetry, children found use of his dialect poetry beyond that value.

By the 1980s, the advent of multiculturalism helped shape the children's literature markets. McKissack's work represents the late twentieth-century push to remember an African American past as well as push for more social justice awareness within children's literature. Multiculturalists used Dunbar's plantation dialect poetry as a benchmark for the study of rural southern blacks. Unlike Bryan, McKissack values Dunbar's dialect poetry and explains that the world saw its value. His work spoke to the growing demand for representation on bookshelves. Fortunately for Dunbar's reputation, multiculturalists held positive attitudes toward dialect poetry. Dunbar did not merely create stereotypical images of our race, he imbued his characters with distinctive feelings that were born from our unique positions in society. Dunbar's poetry represented a lost heritage that could be retrieved through the humorous and sorrowful songs of his caricatures. His story, as well as the context in which his poems were written, became important features in crafting African American identity in an age of identity politics. McKissack quotes Nikki Giovanni to support this assertion: "Dunbar preserved a part of our history. And accurately" (qtd in McKissack 120). Dunbar had once again retained the prestige and honor as a great poet, but for his dialect poetry.

In the late 1990s Catherine Clinton, an eminent scholar, collected thirty-six poems from renowned poets such as Langston Hughes, Countee Cullen, Gwendolyn Brooks and lesser known talents such as Lucy Terry. I, Too, Sing America: Three Centuries of African-American Poetry, an illustrated collection published by Houghton Mifflin and categorized under Teen and Young 
Adult Poetry, represented a tribute to a historical legacy of black writers who in the new digital age, were fading from youthful imaginations. She features one Dunbar poem: "We Wear the Mask." The poem comments on social survival by emphasizing the need for a group of people to mask their true feelings. The singing that the narrator mentions in the third stanza speaks to the theme of Clinton's collection. The singing of the oppressed in the poem reveal the "ironies of black America" (Clinton, dust jacket). Clinton's collection revealed adults' anxieties around training children to remember their heritage because so much of multiculturalism relied on constructing a shared past. Collections such as Clinton's showcased the literary contributions of African Americans participating in a shared identity.

In order for progress to continue, youth needed to reflect on and remember this shared past. Celebrating African American folkways was good but protesting and producing work that affirmed black pride was even more important in the decade leading to the twenty-first century. "We Wear the Mask" is the most outspoken poem against oppression in Dunbar' oeuvre. Interestingly, the poem never identifies any racial group, yet it has been cited countless times to prove that Dunbar protested against racial oppression. For it to be included in such a dynamic and radical collection means that Dunbar's reputation now rested on his powerful protest verses. Like Phillis Wheatley's critics who sought after traces of protest in her poems, editors used the same tactics for Dunbar's poems. This collection is about the struggle to use one's voice against odds. More importantly, if youth used the voices of the past, they could help shape their futures.

\section{Dunbar in the New Millennium}

By the twenty-first century, Dunbar began making appearances in children's picture books as early as 2001. Children's literature contained more illustrations in books. By the 1950s, graphic designers began exploring visual thinking (Popova). Picture books became a staple as 
publishers began including them more in children's literature sections. Complementing Clinton's work, Words with Wings (2001), an illustrated collection of Black poetry and art for youth, includes “Little Brown Baby” alongside poems from Nikki Giovanni, Gwendolyn Brooks, Lucille Clifton, and many more children's poets. This collection included only twenty poems and works of art, making it very selective. Dunbar's poem lies between Romare Bearden's painting entitled, “The Family” and Rita Dove's poem, "Fifth Grade Autobiography.” Dunbar's poem begins with a loving portrait of a father who dotes on his child and creates a story about the "Buggah-man," while the little boy sits on his father's lap (qtd. in Rochelle). The father expresses his love for his child by telling the "Buggah-man" that he "sha'n't have dis boy" and the little boy hugs him close (qtd. in Rochelle). The speaker ends by telling the little boy, "Wisht you could stay jes' a chile on my breas'-/ Little brown baby wif spa'klin' eyes!" (qtd. in Rochelle). This enchanting poem depicts the love between a father and his son. Stories of absentee black fathers circulated in America as harmful stereotypes of black men. Because Dunbar's poem reverses this stereotype, perhaps Rochelle included it in a multicultural volume of poetry. Multifaceted representations of black life mattered and scenes with fathers and their children proved valuable for young children's literature. Rochelle searched for "authentic" representations of black family life, despite the poem's ties with the minstrel market. The complexity of Dunbar's dialect poetry is lost all for the cause of multiculturalism.

Because of this century's focus on bringing awareness of multiculturalism to children, Rochelle essentializes the dialect Dunbar used and calls it "the spoken language of African Americans" (Rochelle). Perhaps Rochelle makes this claim because of the century's focus on what constituted heritage for African Americans. Rochelle does not mention the minstrelsy of the time period, which is the context in which Dunbar wrote. The battle between what constituted 
constructed language and how it was conceived as heritage continues to be waged to this day.

The book leaves children with an impression of an essentialized form of speech of African Americans, which entails negative ramifications. Instead of expressing the multiplicity of African-American cultures, it confines African American speech to limited representations. Rochelle's collection for children shows the need to continue to educate adults and children about misrepresentations of African Americans.

Over ten years passed before Dunbar received another mention in a collection meant for children until Karen L. Kilcup and Angela Sorby's Over the River and Through the Wood appeared in 2013. These editors sought to bring awareness to canonical and lesser-known nineteenth-century children's poems and authors. This expansive anthology features an array of poets from the nineteenth century, some of which experimented with the genre. Both editors explain that their thematic approach to this anthology is meant to bring poems into conversation with one another and into larger conversations surrounding transatlantic scholarship, book history, and sentimentalism (Kilcup and Sorby 3). Their attempts to bring awareness to nineteenth-century poetry in general and children's poetry, specifically resonates with modern readers. Without complex contexts framing the way nineteenth-century readers experienced each poem, modern readers have the opportunity to shape their responses to the text based on critical reading.

Both editors pull a few poems from Dunbar's oeuvre not previously circulated in children's texts including: "The Seedling," "When a Feller's Itchin' to be Spanked," and “The Sandman." One of the poems, "Little Brown Baby," is mentioned several times throughout the early twentieth century. Kilcup explains that she and Sorby "included texts that were explicitly addressed to children, poems that appeared in contemporaneous anthologies, and verse from 
'children's sections' of family publications such as magazines" (Kilcup, "Re:”). They argue that children's poetry as a genre is hard to define and that we should instead consider how children's poetry functioned as contact zones where child and adult both registered mixed motives and competing desires (2). Considering Dunbar's poetry's use-value as both for adults and children, it's clear that he was in this category. His poetry could "voice adult aspiration and fears" while at the same time provide an agenda for children (Kilcup and Sorby 2).

In all four poems, Dunbar clearly addresses a youthful audience. Their selections make it clear that children were the intended audience, even if Dunbar's poems found in early twentiethcentury children's works were not addressed directly to children. The reception of Dunbar's poetry points to the desires of adults who circulated poetry to teach lessons, play, heritage, and verse. Because both editors are selecting poems from his oeuvre that directly address children, their selections do not represent the history of Dunbar's poems' circulation. In their collection, Dunbar's "The Seedling" is in conversation with traditions of representing childhood through nature. In the section entitled, "Growing Things" Dunbar's poem shares space with Christina Moody's "The Little Seed." Moody a teenage child, wrote the poem and personified a seed that grew up to be a wonder to behold (36). Dunbar's poem speaks on a similar theme where a seed speaks and proclaims that he will do the best that he can to grow into a beautiful flower. In his poem, the narrator directly addresses "little folks" and tells them to

...be like the seedling

Always do the best you can

Every child must share life's labor

Just as well as every man. (36) 
According to both editors, many connected childhood with nature in order to represent children as natural and untainted. Their desires were to keep children as pure as possible and preserving this need culminated into literature that did the same.

Dunbar's poem, however, blurs the line between child and adult in its natural world. In the poem, the narrator tells children that they must labor in the same ways as adults. His poem speaks on age-appropriate tasks for children so that they can be useful possibly as farmers because of America's agricultural tradition. The poem speaks of labor as if it is held in high regard; what is also important to consider is what the poem does not speak about-leisure. The fact that the editors placed the poem right before the "Landscapes and Seasons" section which features John Greenleaf Whittier's “The Barefoot Boy” suggests that both poems should be considered in conversation with the other. Both share interesting continuities and contrasts between labor and leisure in the natural world. Whereas Dunbar's seedling labors and strives for his best so that the world will reward his hard work, Whittier's barefoot boy enjoys the pleasures of the earth by simply existing. This contrast signals two existing romanticized views in antebellum and postbellum children's literature. The authors' experiences could color the ways labor and leisure function and possibly Dunbar's poetics speak to his own experiences with laboring and reward.

Another poem noteworthy of mentioning is "Little Brown Baby" in this collection, as it is also placed in a "Family Ties" section but speaks more to universal feelings of family life. Similar to Rochelle's collection in 2001 , these editors aptly name their section to represent the ties between family members. However, unlike Rochelle's collection, Kilcup and Sorby place the poem among sarcastic poems about selling babies at auctions because of their crying and the jealousy an older sibling experiences from a new addition in the family. The placement sparks 
interesting conversations between playful sarcasm in Dunbar's poem and the playfulness of the family dynamic in general. The stressors that young children bring to siblings and parents becomes material for A.R. Wells and Katharine Forrest Hamill to use in "Going! Going!" and "The New Brother" respectively. Dunbar's poem also illustrates a family dynamic where a father pretends to give his son to "the Buggah-man." Placing these poems together allows them to speak about general experiences with family, love, and stress. Additionally, Dunbar's work with portraying enslaved people fashions a new understanding for this context. Readers rethink the light-heartedness of "Going! Going!" when reading Dunbar's portrayal of an enslaved father doting on his son. Without this context, these themes are not as clear. Both editors avoid the trap of using this poem to represent authentic black family dynamics and instead places it in conversation with other sarcastic poems to speak about universal feelings of love, stress, family, and enslavement.

The most recent children's text, Jump back, Paul (2015) reflects late twentieth-century desires to represent Dunbar through his dialect poetry. The collection also used cultural markers to speak on African American identity. Sally Derby, who states that she is "not of the same sex, race, or time period as Paul Laurence Dunbar" creates a narrator who speaks in dialect (119). Though not plantation dialect, the voice assumes a grandmother-like character. The opening lines of the text read, "You never heard of the poet Paul Laurence Dunbar? Child, where've you been?" (1). With her direct address and use of vernacular, the narrator seems to mimic a similar tone that Dunbar's dialect poetry portrayed. Whether this is a form of minstrelsy in and of itself is up for debate. The author uses dialect to introduce the plantation dialect of Dunbar's poems, such as "A Negro Love Song," whose refrain, "Jump back honey, jump back" is featured in the title of the text. This is a first in children's texts and not entirely a successful feat. For one, 
readers can get the idea that the author creates a stereotypical character to perform the same way that Dunbar's characters did in the minstrel market. The narrator is reminiscent of the "mammy" character who guides and prods children to understand Dunbar's story. The narrator introduces several Standard English texts, one of them being "We Wear the Mask." Despite its many similarities with Gould's, Bryan's and McKissack's biographies, its distinctive quality is its tone.

Contemporary accounts of Dunbar's life and poetry work to construct a complete picture of the sometimes happy and sometimes sad poet. From as early as the turn of the century, Dodd, Mead began churning out illustrated collections of Dunbar's already published works that influenced the ways readers conceptualized African Americans. The Hampton Institute's Camera Club, a mainly all-white mediocre organization in a predominantly black institution, took photos of African Americans living near the institute and used them to illustrate Dunbar's poems. From then on, critics and editors sought to produce literature that was age-appropriate for their readers. Poems such as "Little Brown Baby" became a mainstay in most children's collections. The popularity of this poem attested to its immense use for cultivating family values. As the Jim Crow era in U.S. history waged on, children's literature reflected the need to help children escape such a devasting life. Editors collected the more positive poems of Dunbar's oeuvre that did not necessarily address children but presented positive representations of family life amongst African Americans.

\section{Conclusion}

Though the battle to represent Dunbar as an accommodationist or protest poet continued throughout his posthumous career, today, he is mainly known for his "accurate renderings of the rich and valued black language and culture [he] knew so well” (Derby 98). This development did not occur over night; from the early- to mid-twentieth century, Dunbar's poems circulated within 
white children's publications. Editors often used Dunbar's characterizations of black plantation hands to distort images of blacks, leading to mischaracterizations of African Americans in later children's publications. At the same time, however, black newspapers and editors used Dunbar's Standard English and dialect poems to fashion middle-class markers of status for racial uplift. The Civil Rights movement carried with it a host of possibilities and beginnings for children's literature. The explosion of diverse representation lead editors to seek them in their collections. All while this occurred, Dunbar's poetry remained malleable for each decade's tastes and values. His poetry even flirted with the possibilities of natural landscape representation devoid of racial signifiers in Braithwaite's The Message of the Trees. As we can see, Howells's assessment led to the battle to best represent Dunbar.

Editors found spaces where his poetry could imagine new leaps and bounds and fostered for generations of readers lyrical verses that could easily be performed for hours of entertainment. Dunbar's poetry remains central to generations of children because it repurposed and repackaged values related to childhood. It helped future children's authors to learn how to play with language. It even fostered middle-class family values in "jingles in a broken tongue" that helped establish firm status markers for families. Dunbar's poetry, particularly his dialect poetry in many cases, enhanced childhood. 
Conclusion:

A Re-evaluation of the Early African American Canon

My own concern with the representations of blackness is grounded in my desire to see studies that engage in more ways with African American literature than through its ties to slavery. Collectively, the field recognizes and celebrates the categories of exemplary black adult American writers - independent, literate, and relatively speaking, in positions to change their social conditions. Though attention to admirable adults in the field are needed, the field becomes saturated with those voices. It is time that the field turn its attention to categories that tell different stories about resistance and agency. For instance, Frances Smith Foster's Love and Marriage in Early African America (2008) represents an effort to discuss how black writers imagined love and "clandestine meetings" during slavery and the nadir of African American cultural history (Foster xvii). Perhaps Foster's anthology also insinuates how quickly we are to ignore black signs of humanity that are all too quickly assumed of white writers. Yet, the acts of love and rendezvous during slavery have much to offer to the resistance/agency framework. Nonetheless, today, most anthologies, college and secondary school classrooms present a narrow view of early black American poets' works. The possibilities of their representations are limitless, yet most editors and educators condense their representations to black responses to slavery and awareness of race consciousness.

Most editors and educators search for poems that reveal first-hand accounts of enslaved peoples' experiences in America. While important, it should not be the sole focus of inquiry into early black poets' oeuvres. This is especially true for Phillis Wheatley's reception. Both the Norton and Heath anthologies repurpose Wheatley's “On Being Brought from Africa to America" alongside other poems that are studied for what they reveal about Wheatley's 
responses to slavery. The West Virginia English Language and Arts Common Core curriculum's standard text, Collections (2017) features only two poems from Wheatley in a short section dedicated to black literature (Beers). The editors place the two poems, "To the Right Honourable William" and "On Being Brought" next to each other. The chapter asks that students consider how Wheatley responded to "life in the Colonies" by focusing on the final couplet in the latter poem (156-7). Collections encourages students to focus on Wheatley's reaction to society without delving into the classical references described in both poems. These references lead to deeper understandings of the text and encourage students to pursue other questions related to Wheatley's reception - who understood these references and why are they important? Why aren't the references important to the editors of Collections? How might these references speak to black readers in different time periods?

Not only does Collections focus less on classical references in Wheatley's poetry, but the book also skips several decades of poets to center on Langston Hughes as the next leading black poet. Skipping the works of Horton, Harper, and Dunbar is all too common in most classrooms as this focus is symptomatic of a linear retelling of black literary history and representation. Educators and editors value Wheatley because of her historicity - that is, despite there being earlier black poets, they remember that she was the first famous black poet, therefore, she merits a place in the curriculum. Despite the work that John Shields has done to rehabilitate and diversify Wheatley's representation, the canon continues to value her based on her reaction to colonial slavery. Because Horton was a local celebrity during his life, he was largely forgotten. The curriculum neglects to consider the ways that tracing the uses of black poetry can lead to lines of productive inquiry. For instance, the new line that I traced throughout the project is the ways that editors used black poetry to educate children. Most editors did so to promote a form of 
social justice within children's circles. This important strand has important implications for the ways we envision children's involvement with social justice then and now.

As early as the nineteenth century, white and black abolitionist editors circulated Wheatley's poetry to create responsible child citizens in the U.S. Though children could not be recognized as citizens, the new nation's Republican values emphasized the need to train children as productive citizens to ensure its posterity. Arthur Donaldson, an ex-Quaker abolitionist exemplified this notion as he extended moral instruction to black children and their families. Instructing black children in the early nineteenth century was a radical act in and of itself, though it did not carry with it the radicalness of Harper's social justice poems for children. Nevertheless, Donaldson allowed networks of communication between black child readers and their families, thus connecting communities of black children with writings of early black poets. This writing allowed black children the opportunity to imagine literary freedoms not easily envisioned in Philadelphia in 1811. Eric Gardner defined early networks of communication between black writers through early black periodicals; however, Donaldson's magazine represented an earlier attempt to do so. Given the fact that Donaldson's school failed and that he is white, his work is often left out of this discourse, even when noted black abolitionists and teachers such as Sarah Mapps Douglass attended his school. As his exclusion shows, more attention to the social and material conditions of black literature is desperately needed.

Editors used Horton's poetry to shape the ways nineteenth-century children interacted with each other. Morality and friendship, two central themes of Horton's poetry, helped whitewomen authored children's magazines support their causes. Horton's poetry continued to support the goals of abolitionism. After emancipation, this legacy of Horton's activism poetry for 
children was forgotten and replaced with attention to his purpose as the first southern black poet published in the U.S.

During the mid-to-late nineteenth century, Frances Harper promoted child activism as a service to society and to religion. Harper's poems were circulated in children's magazines for both black and white children, and she read them in spaces where children were. Harper focused on racial uplift ideology to promote class mobility within African American communities. She extended this ideology to children which she believed helped create new societies for uplifting the race. Through her poems, she recycled constructions of childhood to both subvert and comment on the ways black children were portrayed. She granted black children literary agency so that they could imagine themselves as humans in a time when that was not the case. The future depended on morally responsive and self-determined children who continued this legacy of racial uplift. This legacy was largely forgotten because the changing constructions of childhood limited children's responsibilities. Many find that children's roles in social justice should be minor. Oftentimes, when students or young people advocate on social justice issues such as police brutality or climate change, people either diminish their efforts or believe that another adult is behind their work. Harper shows scholars a blueprint for the ways she broadened child activism in an unjust society.

Leading into the turn of the century, editors became enamored with Dunbar's poems so much so that he appeared in children's magazines, even if they worked to demoralize blacks. Dunbar's legacy as a children's author began in white children's magazines and featured three of his poems set for the minstrel market. Though white readers found ways to market them as stereotypical depictions of blacks, black editors and educators recycled the dialect and Standard English poems for their use in cultivating a black middle-class. Black editors found that instead 
of erasing the history of plantation life in the poems, they instead re-marketed them to show how Dunbar captured plantation life experiences. Dunbar became known for this knack of observing early black life in entertaining poems. Editors used these poems to create a history that showed exemplary qualities about black people. They featured positive stories about father/child relationships and stories about struggle and resistance so that black children could mimic these principles as a part of their acclimatization into the black middle class. Dunbar's poetics for children had a far-reaching scope, as he is today remembered as the poet who captured black experiences in a "jingle in a broken tongue." As with his predecessors, Dunbar's legacy as a children's poet is elapsed over his knack for contributing to black heritage.

Once constructions of childhood incorporated separate spheres for children's development in the nineteenth century, the cries from those who advocated the need for children to participate in activism were not heard. Cultural shifts determined the relationships between child and adult, and as new sciences were created for child development, more people began promoting separate conditions for adolescent youth. Children no longer occupied the adult, read mature, spaces and no longer participated in what was seen as adult spheres. This is why when we see children advocating on political or social issues, there is such surprise about how mature they are. Editors, however, sought children's help to advocate for an uplifted society.

As discussed in all chapters, the New Negro aesthetic sought literature that spoke to and for black Americans. It broke away from sentimental and minstrel literature, which many critics found to be in the domain of white literature. Though critics reformed Dunbar's image so that he represented black southern heritage, he could not fully represent the aesthetic of the New Negro like Harlem Renaissance poets such as Langston Hughes, who used elements of the black folk tradition. New Negro critics felt that sentimental and minstrel literature did not rightly represent 
the black experience. What was needed, they claimed, was a literature that expressed the desires of black Americans while drawing from western traditions. Even though poets such as Countee Cullen and Claude McKay embraced the conventional styles of genteel poetry, many others retained an adherence to a black folk tradition. This tradition underwent a transformation from "southern rural roots into an urban vernacular" (Graham). As it appears, Collections focuses on a similar aesthetic as it tries to form a tradition of political writing by black Americans. It teaches students to focus on poetry that brings an awareness of one black experience, when in fact, black experiences are multifaceted. Perhaps the goal to form a tradition thwarts effort to expand representations that fall beyond a tradition of African American writing.

Similarly, editors circulate Horton, Harper, and Dunbar's poems to reveal aspects of black heritage. The need to identify black traditions unique to black heritage stems from the New Negro and Black Arts Movements (1965-1976) and has continued even into the twenty-first century. While distinguishing themselves from an "old aesthetic" (read western aesthetic), Alain Locke, W.E.B. Du Bois, and other black male critics sought to represent black experiences and writing with exceptional voices. New Negro critics ignored black poets who used sentimental and Victorian-esque themes in their poetry. The Black Arts Movement brought about radical depictions of black art, oftentimes focusing on prescriptive definitions of blackness that used a separatist ethos. This, of course, excluded the aforementioned poets because of how they adhered to western traditions of poetry. Though the field has advanced from a separatist ethos, due to the work of black feminist theorists and multiethnic generations, the legacy of shaping a tradition focused on only a few voices of protest remains.

Horton has yet to be considered valuable in the formation of the African American literature tradition in the twenty-first century partly because he is represented as imitative of the 
Romantic tradition of literature. However, Faith Barrett finds value in Horton's imitation because she argues in many of her publications that Horton appropriates western traditions of literature to both resist and elude white authority. Her chapter in Literary Cultures of the Civil War argues that Horton uses a patchwork of imitative techniques that enriches further studies of his Civil War collection. In another collection, she argues also that imitation was used by early black poets to "defuse the threat of their literacy" ("Great and Noble" 34). The originality of one's voice was not as important as the mastery of literary conventions in Horton's time. She explains that his poetry is not suited for New Critical methods of close reading, so it is imperative that we view his work from the contexts in which he lived and wrote (Barrett, “'Naked Genius"” 79). Barrett's argument raises questions regarding the "cultural functions of poetry" that are essential to exposing forgotten uses of his poems (Barrett, “"Naked Genius”” 79).

Barrett's important work reminds us that the uses of Horton's poetry are just as important as the poems themselves. As chapter two has explained, Horton was valued for what his poetry taught children in the nineteenth century. It was used to amplify the voices of black Americans and to help white children sympathize. A couple of his nature poems were used in black publications to help black children imagine freedom through the natural world. After the Civil War, Horton fell into obscurity. The strengthening of Jim Crow laws prohibited educational advancements of many black Americans and hindered many local blacks from disseminating their works. With the exception of Harper, many local blacks who wrote poetry such as Dave the Potter and Horton were forgotten. When African Americans sought education as a way to insert themselves into white society, Horton's romantic and Victorian verses were popular enough to be placed into Newman Ivey White and Walter Clinton-Jackson's 1924 collection. After the goals of black literary movements advanced the literature, Horton's dated poetics no longer held 
value for movements that sought to create their own black aesthetics. The work of feminist theorists and archivists have helped revive poets such as Horton and Harper, though there is still much to be done.

To continue to progress and expand representations of early black poets, scholars must deconstruct race in what some have deemed a "post-racial" society and the categories that celebrate exemplary (read elite) voices. The foundational works for thinking about the unstable social relations of race from Hazel Carby, Kevin Gaines, John Ernest, and others help to unravel the tangled history between racial oppression and the impact on reception of African American poets. Kenneth Warren's scholarship, which advances the notion that the African American literary tradition ended after Jim Crow, does not fully consider the various uses of early black poetry that deny a simplistic understanding of the African American literary tradition. As I have shown in chapter two, social justice activism for black children involved acts of reading about nature and friendship, two subjects that elude easy interpretations of protest. His argument does not consider the uses of print culture, which promoted black citizenship and success in contexts beyond protest.

Black citizenship also complicates Warren's argument. Derrick Spires's work advances my argument by allowing my chapter to show how black poetry created ways for black Americans to focus on their practices of neighborliness. This poetry was more so available for blacks to improve their own understanding of citizenship in their communities, and not necessarily in response to white supremacy. Namely, Harper's poetry symbolized black lowerclass children as angelic and bearers of good will. This line of thinking advanced their perceptions of their abilities to affect change in a society that rebuked their participation. Spire's work has sparked others to reconsider citizenship. Koritha Mitchell's forthcoming book, From 
Slave Cabins to the White House (August 2020) allows for meditation on citizenship and domesticity. She argues that "homemade citizenship is a deep sense of success and belonging that does not rely on civic inclusion or mainstream recognition" (Mitchell). Mitchell complicates the framework that African American literature responds to white-authored violence by suggesting that white violence is a response to Black success (Mitchell).

Indeed, more work could be done to understand the roles children played in shaping their own identities. Extant texts such as The Child's Recorder and The Brownies Book could open up more avenues for discussing children's perceptions of their identities. These two works show how editors trained children to understand their identities through print in the nineteenth and twentieth century, respectively. African American literature benefitted from an examination of the categories that limit our understandings of children's place in protest literature. With the help of print culture, many of the gaps in the canon will continue to fill.

Each of these present-day representations of black writing shows the need to strive to improve understandings of the material, social, and political conditions of African Americans. One way that I propose is to start with the reception histories of early black poets to understand how print culture complicates our twenty-first century interpretations of eighteenth and nineteenth-century black poets. From Wheatley's neo-classical references to Dunbar's children's poems and everything in between, each history reveals how we continue to neglect voices that helped shape a tradition. Forgotten reception histories reveal that our field is yet to be fixed or determined. In fact, reception histories challenge our efforts to form quick canons and contexts because as recovery work continues to excavate lost voices, we find ourselves scrambling to rethink our hastiness. In the face of critics who argue the need to disengage the field from racial inquiry, reception histories help scholars refute claims of resolution with this critical lens. 


\section{Works Cited}

African Repository and Colonial Journal (1825-1825). vol. 19, no. 8, Aug 1843, pp. 256.

ProQuest, https://search-proquest-com.

Ancestrylibrary.com. U.S., Quaker Meeting Records, 1681-1935. Provo: Ancestry.com

Operations, Inc., 2014.

---. “02 May 1809.” U.S., Quaker Meeting Records, 1681-1935. Provo: Ancestry.com

Operations, Inc., 2014. Ancestrylibrary.com. https://search.ancestrylibrary.com/.

---. “17 Oct. 1808, Event Type: Marriage.” U.S., Quaker Meeting Records, 1681-1935. Provo:

Ancestry.com Operations, Inc., 2014. Ancestrylibrary.com.

https://search.ancestrylibrary.com/

American Psychological Association. "Black Boys Viewed as Older, Less Innocent Than

Whites, Research Finds.” APA.org. 2014.

https://www .apa.org/news/press/releases/2014/03/black-boys-older

Anderson, James D. The Education of Blacks in the South, 1860-1935. University of North Carolina Press, 1988.

Anderson, Melinda D. “The Other Student Activists.” The Atlantic. 2015. https://www .theatlantic.com/education/archive/2015/11/student-activism-historyinjustice/417129/

Anderson, Mareen. “Phillis Wheatley's Dido: An Analysis of 'An Hymn to Humanity.' 'To S.P.G. Esq."” Ed. John C. Shields and Eric D Lamore. New Essays on Phillis Wheatley. University of Tennessee Press, 2011.

Anti-Slavery Bugle. "Our Paper.” Chronicling America. June 20, 1845. https://chroniclingamerica.loc.gov/lccn/sn83035487/1845-06-20/ed-1/seq-1/ 
---. Edited by Marius Robinson, Ohio American Antislavery Society, 1845-

1861. https://chroniclingamerica.loc.gov/lccn/sn83035487/

Bacon, Jacqueline. The Humblest May Stand Forth: Rhetoric, Empowerment, and Abolition. University of South Carolina Press, 2002.

Bacon, Margaret, Hope. “One Great Bundle of Humanity”: Frances Ellen Watkins Harper (1825-1911). Gale Literature and Resource Center, http://search.ebschost.com.

Baker, Houston A. Blues, Ideology, and Afro-American Literature: A Vernacular Theory. Chicago: University of Chicago Press, 1987. Print.

Bassett, William. Society of Friends in the United States: Their Views of the Anti-Slavery question, and Treatment of the People of Colour. Archive.org. Web. https://archive.org/details/societyoffriends00bass_1/page/22

Baxter, Jane Eva, and Meredith Ellis. "Introduction: 19th Century Childhoods in Interdisciplinary and International Perspectives.” Nineteenth Century Childhoods in Interdisciplinary and International Perspectives. Edited by Jane Eva Baxter and Meredith A. B. Ellis, vol. 6, Oxbow Books, Oxford; Philadelphia, 2018, pp. 112. JSTOR, www.jstor.org/stable/j.ctvh1dh7v.5.

Beers, Kylene, et al. Collections. Houghton/Mifflin Harcourt. 2017 Print.

Beman, Amos Gerry. “The Education of the Colored People.” Anglo-African Magazine. Vol 1 Issue 11 Nov 1859. 337-339, http://search.ebschost.com. 
Bernstein, Robin. Racial Innocence: Performing American Childhood and Race from Slavery to Civil Rights. New York University Press, 2011. Gale Literature Resource Center, http://search.ebschost.com.

Bishop, Rudine Sims. Free Within Ourselves: The Development of African American Children's Literature. Heinemann, 2007.

Between the Covers: Rare Books Inc. "Dunbar, Paul Laurence.” Bibliopolis. Web. Accessed on Dec. 26, 2019. https://www.betweenthecovers.com/pages/books/87577/paul-laurencedunbar/lyrics-of-lowly-life

Blount, Marcellus. “The Preacherly Text: African American Poetry and Vernacular Performance.” PMLA, vol 107, no. 3, 1992.pp. 582-593. DOI: $10.2307 / 462763$.

Braithwaite, William Stanley. The Message of the Trees: An Anthology of Leaves and Branches. Ed. Maud Cuney-Hare, Cornhill, 1918.

Brawley, Benjamin Griffith, 1882-1939. Early Negro American Writers: Selections With Biographical And Critical Introductions. Freeport, N.Y.: Books for Libraries Press, 1968.

---. “Three Negro Poets: Horton, Mrs. Harper, and Whitman.” The Journal of Negro History, vol. 2, no. 4, 1917, pp. 384-392. JSTOR, www.jstor.org/stable/2713396.

Brawley, Benjamin. Paul Laurence Dunbar: Poet of His People, 1936. Print.

Brooks, Joanna. “Our Phillis, Ourselves.” American Literature, vol. 82, no. 1, 2010, pp. 1-28. https://read.dukeupress.edu/american-literature/article/82/1/1-28/4787.

Brown, James. “Say it Loud.” Posted by BlackConsumers. Youtube. Mar. 20. 2011. https://www. youtube.com/watch?v=9bJA6W9CqvE 
Brown, William Wells. The Black Man: His Antecedents, His Genius, and His Achievements. Documenting the American South. New York: Thomas Hamilton, 1863.

---. The Black Man, His Antecedents, His Genius, and His Achievements. 2nd ed., rev. and ed. T. Hamilton, 1968.

---. The Rising Son; or, the Antecedents and Advancement of the Colored Race.

Boston: A.G. Brown, 1874; New York, Negro Universities Press. Print. HeinOnline, https://heinonline.org.

Bryan, Ashley. I Greet the Dawn: Poems by Paul Laurence Dunbar. New York: McClelland \& Stewart, 1978. Print.

Butchart, Ronald E. Schooling the Freed People: Teaching, Learning, and the Struggle for Black Freedom, 1861-1876, University of North Carolina Press, 2013. ProQuest Ebook Central, https://ebookcentral.proquest.com.

Carby, Hazel V. Reconstructing Womanhood: The Emergence of the Afro-American Woman Novelist. Oxford University Press, 1990.

Carretta, Vincent. Unchained Voices: An Anthology of Black Authors in the English-Speaking World of the Eighteenth Century. Expanded ed., Expanded ed., University Press of Kentucky, 2004.

Chandler, Karen. “'Ye are Builders': Child Readers in Frances Harper's Vision of an Inclusive Black Poetry." Who Writes for Black Children?: African American Children's Literature before 1900. University of Minnesota Press, 2017. Katharine Capshaw Smith and Anna Mae Duane.

The Chapel Hill Weekly Gazette. Chapel Hill, N.C: Ed. James M. Henderson, 1857. Ancestry, www.newspapers.com. 
Child, Benjamin. “The Plantation Countermelodies of Dunbar and Du Bois: Writing Agropolitical Subjecthood in the Nadir.” American Literature, vol. 91, no. 3, 2019, pp. 557-586. https://www.dukeupress.edu/.

Child, Lydia Maria. “Address to the Young.” Juvenile Miscellany. Vol. 1, no. 1, Sept. 1826. vii. http://search.ebschost.com.

---. "Education of Children.” The Freedmen's Book. Ticknor and Fields, 1865. pp. 221. HeinOnline, https://heinonline.org.

---. The Freedmen's Book. Ticknor and Fields, 1865. HeinOnline, https://heinonline.org.

The Child's Recorder. Ed. Charles S. Smith. Nashville: S.S. Union of the A.M.E. Church. 18891891. Microfilm. Michigan Historical Collection of the University of Michigan. Reel 1. “Children in History.” Christian Recorder. Vol. 1 Issue 22 Jun 8, 1861. https://www .accessible-archives.com/.

The Children's Magazine: Calculated for the Use of Families and Schools (1789-1789), vol.04, 1789, pp. 143. ProQuest, https://www.proquest.com/.

Christian Reflector. vol. 3, no. 1 - v. 11, no. 19. Worcester: Board of Managers of the Baptist Denomination, 1840-1848.

Christian Secretary. Vol 1, no.1-vol 75, no. 15. Hartford: n.p., 1822-1896.

Clark, Beverly Lyon. Kiddie Lit: The Cultural Construction of Children's Literature in America. Johns Hopkins University Press, 2005.

Clarkson, Thomas, and Thomas Charles Colyear Portmore. An Essay on the Slavery and Commerce of the Human Species, Particularly the African. 3rd ed. London, 1787. EECO. https://www .gale.com/. 
Clinton, Catherine. I, Too, Sing America: Three Centuries of African-American Poetry. Boston: Houghton Mifflin, 1998. Print.

Cohen, Lara Langer, and Jordan Alexander Stein, editors. Early African American Print Culture. ebook, University of Pennsylvania Press, 2012.

Cohen, Michael C. The Social Lives of Poems in Nineteenth-Century America. University of Pennsylvania Press, 2015.

---. Cultures of Poetry in Late Nineteenth-Century America.

New York University, 2007. Ann Arbor: ProQuest Dissertations Publishing.

Cohen, William B, et al. "On the Cultural Achievements of Negroes.” The International Journal of African Historical Studies, vol. 32, no. 1, 1999, pp. 175-175., doi:10.2307/220835.

Comfort, William Wistar, et al. The Quakers: A Brief Account of Their Influence on Pennsylvania. Pennsylvania Historical Assn, 1948.

Cowper, William. "The Following Contains Something so Calculated to Impress on the Minds of Youth the Necessity of Obedience to Parents, that we Request their Attention Thereto: 'Christian Freedom'" The Juvenile Magazine (1811-1813), no. 1, May 01, 1811, pp. 20. https://www .proquest.com/.

Cromwell, Otelia, Lorenzo Turner, and Eva Dykes. Readings from Negro Authors for Schools and Colleges. New York: Harcourt, Brace. 1931. Print.

Donaldson, Arthur. Juvenile Magazine. May 1. 1811 -August 1, 1813, Philadelphia. Proquest. https://www .proquest.com/.

DeLombard, Jeannine, "African American Cultures of Print." A History of the Book in America, vol. 3. 1840-1880. American Antiquarian Society. North Carolina Press, 2007. 
Derby, Sally. Jump Back, Paul: The Life and Poems of Paul Laurence Dunbar. Humen: Candlewick Press, 2015. Print.

Dodge, Mary Mapes. “Three Humorous Negro Poems.” St. Nicholas. Vol. 29. 1901. Google Books. https://books.google.com/books?id=pmoyAQAAMAAJ\&lpg=PA1190\&ots=uB4VUPGb pI\&dq=St.\%20Nicholas\%20paul\%20laurence\%20dunbAr\&pg=PA1190\#v=onepage \&q= paul\%20laurence $\% 20$ dunbAr\&f=false.

Donaldson, Arthur. The Juvenile Magazine (1811, 1813). no.1-4. Philadelphia. Proquest. https://www.proquest.com/.

Du Bois, W.E.B. The Brownies' Book. New York, N.Y .: DuBois and Dill, 1920-1921. Library of Congress. https://lccn.loc.gov/22001351

---. "Editorial." The Crisis: A Record- The Darker Races. The Modernist Journals Project. Vol 1 issue 6 April 1911. http://www.modjourn.org/render.php?id=1274706581234375\&view=mjp_object

---. "Frances Ellen Watkins." The Works of William Wells Brown: Using his ‘strong, manly voice.’” Eds. Paula Garrett and Hollis Robbins. Oxford University Press, 2006. Ebscohost, http://search.ebschost.com.

---. "What to Read. Hazel-Book Review of 'Hazel' by Mary White Ovingon.” The New Year Crisis. vol 7, no. 3. New York: NAACP, 01 Jan 1914. Modernist Journals Project, https://modjourn.org/issue/bdr517728/.

---. The Souls of Black Folk: Essays and Sketches. Archive.org. Chicago: A. C. McClurg \& Company, 1903. https://archive.org/details/cu31924024920492/page/n123 
Dunbar, Paul Laurence. "Christmas Carol.” Christmas gif': An Anthology of Christmas Poems, Songs, and Stories. Ed. Charlemae Hill Rollins. New York: Morrow Junior Books, 1993. Archive.org, https://archive.org/details/christmasgifanth00roll/page/n23.

---. "Christmas Is A-Comin"” Christmas gif': An Anthology of Christmas Poems, Songs, and Stories. Ed. Charlemae Hill Rollins. New York: Morrow Junior Books, 1993. Archive.org. https://archive.org/details/christmasgifanth00roll/page/n23.

---. Little Brown Baby. Ed. Bertha Rodgers. Little Brown Baby: Poems for Young People. New York: Dodd, Mead, 1940. NYPL. https://digitalcollections.nypl.org/items/b2becfa0-ca2c-0134-78b600505686a51c/book\#page/17/mode/2up

---. “A Little Christmas Basket.” Christmas gif': An Anthology of Christmas Poems, Songs, and Stories. Ed. Charlemae Hill Rollins. New York: Morrow Junior Books, 1993. Archive.org. https://archive.org/details/christmasgifanth00roll/page/n23

--. Lyrics of a Lowly Life. New York: Young People's Missionary

Movement of the United States and Canada (Variant Issue), 1896. Print.

---. Majors and Minors. New York: Dodd, Mead. 1895. Print.

---. “Noddin’ By De Fire” The Century Illustrated Monthly Magazine. Eds.

Gilder, Richard Watson and Josiah Gilbert Holland. New York: Scribner \& Co. The Century Co, 1901.

https://babel.hathitrust.org/cgi/pt?id=mdp.39015016779160\&view=1up\&seq=34

---. Oak and Ivy. Ohio: Press of United Brethren Publishing House, 1893.

Google Books. https://books.google.com/books?id=wG06AQAAMAAJ\&pg=PP7\#v=onepage \&q\&f=fale 
---. Old Abe’s Conversion. Youth's Companion. Vol. 74. 1900. HathiTrust.

https://babel.hathitrust.org/cgi/pt?id=njp.32101079674790\&view=1up\&seq=18

---. "The Poet.” Wright State University Special Collections.

https://www.libraries.wright.edu/special/dunbar/poetry/198

---. "The Seedling.” The Dunbar Speaker and Entertainer: Containing the Best Prose

And Poetic Selections by And About the Negro Race: With Programs Arranged for

Special Entertainments. Ed. Dunbar-Nelson, Alice Moore. Naperville. J. L. Nichols \&

Co., 1920. HathiTrust.

https://babel.hathitrust.org/cgi/pt?id=emu.010000124897\&view=1up\&seq=1

---. “The Sparrow's Fall.” The Dunbar Speaker and Entertainer: Containing the Best Prose And Poetic Selections by And About the Negro Race: With Programs Arranged for Special Entertainments. Ed. Dunbar-Nelson, Alice Moore. Naperville. J. L. Nichols \& Co., 1920. HathiTrust.

https://babel.hathitrust.org/cgi/pt?id=emu.010000124897\&view=1up\&seq=1

---. Speakin' O' Christmas: And Other Christmas And Special Poems. New York: Dodd, Mead and company, 1914.

---. “The Suitor.” The Century Illustrated Monthly Magazine. Eds. Gilder, Richard Watson and Josiah Gilbert Holland. New York: Scribner \& Co. The Century Co, 1901. https://babel.hathitrust.org/cgi/pt?id=mdp.39015016779160\&view=1up\&seq=34

---. "The Sun.” Northwestern Christian Advocate. Ed. David D. Thompson. Vol. 55. July 31, 1907. Google Books.

https://books.google.com/books?id=KG0xAQAAMAAJ\&pg=PP2\#v=onepage \&q\&f=fals

e 
---. “A Virginia Reel.” The Century Illustrated Monthly Magazine. Eds. Gilder, Richard Watson and Josiah Gilbert Holland. New York: Scribner \& Co. The Century Co, 1901. https://babel.hathitrust.org/cgi/pt?id=mdp.39015016779160\&view=1up\&seq=34

Dunbar-Nelson, Alice Moore. The Dunbar Speaker and Entertainer: Containing the Best Prose And Poetic Selections by And About the Negro Race: With Programs Arranged for Special Entertainments. Naperville. J. L. Nichols \& Co., 1920. HathiTrust. https://babel.hathitrust.org/cgi/pt?id=emu.010000124897\& view=1up\&seq=1

Dungy, Camille T, editor. Black Nature: Four Centuries of African American Nature Poetry. University of Georgia Press, 2009.

Duyckinck, Evert A. (Evert Augustus), 1816-1878, Michael Laird Simmons, and George L. (George Long) Duyckinck. Cyclopadia of American Literature: Embracing Personal And Critical Notices of Authors, And Selections From Their Writings, From the Earliest Period to the Present Day; With Portraits, Autographs, And Other Illustrations. Philadelphia: W. Rutter, 1875.

Eckstrom, D. L. Untimely Verse: Distressed Publishing and Exemplary Circulation in Antebellum America, Tufts University, Ann Arbor, 2018. ProQuest, https://www.proquest.com/.

Elliott, Robert N. The Raleigh Register, 1799-1863. University of North Carolina Press, 1828.

Ellis, Cristin. Antebellum Posthuman: Race and Materiality in the Mid-Nineteenth Century. First edition., First ed., Fordham University Press, 2018. Encyclopedia of African-American Writing 2nd Edition, Ed. Sherry Hatch. Grey House Publishing, 2009. ProQuest Ebook Central, https://ebookcentral.proquest.com/. 
The Epworth Herald. “A Second Reference Library for Mission Study.” Vol.15, April 29, 1905. GoogleBooks, https://books.google.com.

Ernest, John. Liberation Historiography: African American Writers and the Challenge of History, 1794-1861. The University of North Carolina Press, 2004. EBSCOhost, http://ww8.ebschost.com/

Faith Barrett. "Great and Noble Lines: Dave the Potter, George Moses Horton, and the Possibilities of Poetry." Where is all My Relation: The Poetics of Dave the Potter. Oxford University Press, 2018.

---. “'Naked Genius:' The Civil War Poems of George Moses Horton.” Literary Cultures of the Civil War. p.77. University of Georgia Press, 2016.

Follen, Eliza. "Methods of Teaching." The Child's Friend and Family Magazine (18431858). vol. 1, no. 6, Mar 01, 1844, pp. 209. ProQuest, https://www.proquest.com/.

---. "The Mother and Her Child." The Child's Friend and Family Magazine (18431858). Boston, vol. 6, no. 2, 01 May 1846,pp. 57. ProQuest, https://www .proquest.com/.

Forten, Charlotte L. The Journals of Charlotte Forten Grimké. Edited by Brenda E Stevenson, Oxford University Press, 1988, Print.

Foster, Frances Smith. A Brighter Coming Day: A Frances Ellen Watkins Harper Reader. New York. Feminist Press, 1990, Print.

---. Love and Marriage in Early African America. Boston: Northeastern University Press, 2008. Freeman, M.H. “The Educational Wants of the Free Colored People.” Anglo-African Magazine. Vol 1 issue 4, Apr 1859. 115-119. http://ww8.ebschost.com/. 
Gaines, Kevin Kelly. Uplifting the Race: Black Leadership, Politics, and Culture in the Twentieth Century. University of North Carolina Press, 1996. Ebscohost, http://ww8.ebschost.com/.

Gardner, Eric. Black Print Unbound: The Christian Recorder, African American Literature, and Periodical Culture. New York: Oxford University Press, 2015. Print.

Garrett, Paula and Hollis Robbins. "Introduction.” The Works of William Wells Brown: Using his ‘strong, manly voice”” Oxford University Press, 2006. Ebscohost. http://ww8.ebschost.com/.

Gates, Henry Louis. The Trials of Phillis Wheatley: America's First Black Poet and Her Encounters with the Founding Fathers. Basic Civitas Books, 2010.

Genius of Universal Emancipation and Baltimore Courier (1825-1825). Vol 1. No. 2. Aug. 1821 ProQuest. https://www.proquest.com/.

Gilder, Richard Watson, and Josiah Gilbert Holland. The Century Illustrated Monthly Magazine. New York: Scribner \& Co. The Century Co, 1901. https://babel.hathitrust.org/cgi/pt?id=mdp.39015016779160\&view=1up\&seq=34.

Giovanni, Nikki. "Afterword.” Ed. Jay Martin. A Singer in the Dawn: Reinterpretations of Paul Laurence Dunbar. Internet Archive, New York: Dodd, Mead, 1975, archive.org/details/singerindawnre00cent.

Gould, Jean. That Dunbar Boy: The Story of America's Famous Negro Poet. New York: Dodd, Mead. 1958. Archive.org. https://archive.org/details/thatdunbarboysto00goul/page/n1 Golding, Alan. "A History of American Poetry Anthologies." Ed. Robert Von Hallberg. Canons. University of Chicago Press, 1984. 
Graham, Maryemma. “The New Negro Renaissance.” Africana Age. http://exhibitions.nypl.org/africanaage/essay-renaissance.html.

Gray, Janet Sinclar. Race and Time: American Women's Poetics from Antislavery to Racial Modernity. University of Iowa Press, 2004. Ebscohost, https://www.ebsco.com/.

Green, James N. "The Rise of Book Publishing." An Extensive Republic: Print, Culture, and Society in the New Nation, 1790-1840. Eds. Robert Gross and Mary Kelley. Published in Association with the American Antiquarian Society by the University of North Carolina Press, 2010.

Grégoire, Henri. An enquiry concerning the intellectual and moral faculties, and literature of negroes: followed with an account of the life and works of fifteen negroes and mulattoes, distinguished in science, literature and the arts. Translated by David Bailie Warden. Brooklyn: T. Kirk, 1810. Project Gutenberg, https://www.gutenberg.org/files/15907/15907-h/15907-h.htm\#footnotetag333.

Grégoire, Henri, Thomas Cassirer, and Jean-Francois Briére. On the Cultural Achievements of Negroes. University of Massachusetts Press, 1996. Ebscohost, https://www.ebsco.com/. Guillory, John. Cultural Capital: The Problem of Literary Canon Formation. University of Chicago Press, 1993.

Gundaker, Grey. "Give Me a Sign: African Americans, Print, and Practice." A History of the Book in America, Volume 2: An Extensive Republic: Print, Culture, and Society in the New Nation, 1790-1840, Eds. Robert A. Gross, and Mary Kelley, University of North Carolina Press, 2010. ProQuest Ebook Central, https://ebookcentral.proquest.com. 
Hamilton, Thomas. “Apology.” Anglo-African Magazine. Ebscohost, [s.n.]. https://www.ebsco.com/.

Harper, Frances Ellen Watkins. "Advice to the Girls.” The Black Man: His Antecedents, His

Genius, and His Achievements. Ed. William Wells Brown. Documenting the American South.

New York: Thomas Hamilton, 1863. https://docsouth.unc.edu/neh/brownww/menu.html.

---. "Advice to the Girls." The Black Man: His Antecedents, His Genius, and His Achievements.

Documenting the American South. Ed. William Wells Brown. New York: Thomas

Hamilton, 1863. https://docsouth.unc.edu/neh/brownww/menu.html.

---. “As Full as the Room Was.” A Brighter Coming Day: A Frances Ellen Watkins Harper Reader. Ed. Frances Smith Foster. Feminist Press, New York. 1990. Print.

---. "Days of My Childhood.” Anti-Slavery Bugle. Chronicling America. September 29, 1860. $<$ https://chroniclingamerica.loc.gov/lccn/sn83035487/1860-09-29/ed-1/seq-4/>

---. Forest Leaves. Printed by James Young, Baltimore. 1849. Maryland Historical Society, https://www.mdhs.org.

---. Iola Leroy: Or, Shadows Uplifted. Edited by Koritha Mitchell, Broadview Press, 2018.

---. "Jamie's Puzzle." Over the River and through the Woods: An Anthology of NineteenthCentury American Children's Poetry. Eds. Karen Kilcup and Angela Sorby. Johns Hopkins University Press, 2014.

---. "Letters. Green Plain, O. Sept. 21, 1860.” Anti-Slavery Bugle. Chronicling America. vol 16. No.7. https://chroniclingamerica.loc.gov/lccn/sn83035487/1860-0929/ed-1/ 
---. "The Little Builders" Over the River and through the Wood: An Anthology of NineteenthCentury American Children's Poetry. Eds. Karen L. Kilcup and Angela Sorby. Johns Hopkins University Press, 2014.

---. "Moses, A Story of the Nile." Ebony Angels: A Collection of African-American Poetry and Prose. Ed. Faith Jayox. Three Rivers Press, 1996.

---. "Our Greatest Want." Anglo-African Magazine. Vol 1 issue 5 May 1859. 160. Ebscohost, https://www.ebsco.com/.

--- "A Private Meeting with the Women.” A Brighter Coming Day: A Frances Ellen Watkins Harper Reader. Ed. Frances Smith Foster. Feminist Press, New York. 1990. Print.

---. Sketches of Southern Life. Works of Frances E. Watkins Harper (1872), Microfilm. 1 Reel. $35 \mathrm{Mm}$. Volume 3, 1969.

---. "The Slave Mother." The Black Man: His Antecedents, His Genius, and His Achievements. Documenting the American South. Ed. William Wells Brown. New York: Thomas Hamilton, 1863.

---. "Thank God for Little Children.” The Freedmen's Book. Ed. Lydia Maria Child. Ticknor and Fields, HeinOnline, 1865

--- "We Are All Bound up Together." A Brighter Coming Day: A Frances Ellen Watkins Harper Reader. Ed. Frances Smith Foster. Feminist Press, New York. 1990. Print

---. "What a Field There is Here." A Brighter Coming Day: A Frances Ellen Watkins Harper Reader. Ed. Frances Smith Foster. Feminist Press, New York. 1990. Print.

---. “Woman's Political Future.” Voices of Democracy. https://voicesofdemocracy.umd.edu/harper-womens-political-future-speech-text/ 
---. "Youth in Heaven.” Anglo-African Magazine. Vol 2, issue 2, February 1860. P. 64. https://www.ebsco.com/

Harper's Young People. Ed. Kirk Munroe. New York: Harper and Brothers. 1879-1895. Project Gutenberg, https://www.gutenberg.org/wiki/Harper\%27s_Young_People_(Bookshelf).

Hawthorne, Nathaniel. Letters of Hawthorne to William D. Ticknor, 1851-1864.Newark, N.J.: The Cartetet book club, 1910.

---. “Little Annie's Ramble.” Anti-Slavery Bugle. Chronicling America. 31 Oct. 1845. Chronicling America. https://chroniclingamerica.loc.gov/lccn/sn83035487/1845-10-31/ed-1/seq-4/>. Helm, Mary. The Upward Path: The Evolution of a Race (Classic Reprint). Forgotten Books, 2016.

Hill, Leslie Pinckney. "Foreword." The Dunbar Speaker and Entertainer: Containing the Best Prose and Poetic Selections by And About the Negro Race: With Programs Arranged for Special Entertainments. Ed. Alice Moore Dunbar-Nelson. Naperville. J. L. Nichols \& Co., 1920. HathiTrust. https://babel.hathitrust.org/cgi/pt?id=emu.010000124897\&view=1up\&seq=1

Hollander, John. American Poetry: The Nineteenth Century. Literary Classics of the United States, 1993.

Hollander, John, and Sally Wern Comport. Poetry for Young People American Poetry. Scholastic, 2004.

Horne, Gerald, and Mary Young. W.E.B. Du Bois: An Encyclopedia. Greenwood Press, 2001. 
Horton, George Moses. "Address to Collegiates of the University of N.C.: The Stream of Liberty and Science," Documenting the American South, UNC Chapel Hill, 1859, https://docsouth.unc.edu/southlit/horton1859/hortonaddress.html\#7a.

---. The Hope of Liberty Containing a Number of Poetical Pieces. Raleigh, J. Gales and Son, 1829. Documenting the American South. https://docsouth.unc.edu/southlit/horton/horton.html.

---. "Meditations on a Cold, Dark and Rainy Night." An Anthology of Verse by American Negroes. Eds. White, Newman Ivey, and Walter Clinton Jackson. Trinity College Press, 1924.

---. “On Summer." African-American Poetry of the Nineteenth Century: An Anthology. Ed. Joan R. Sherman. University of Illinois Press, 1992.

---. The Poetical Works of George M. Horton: The Colored Bard of North-Carolina: to which is prefixed The Life of the Author, Archive.org, 1845. https://archive.org/details/poeticalworksofg00hort/page/n4/mode/2up.

---. "Praise of Creation." The Freedmen's Book. Ed. Lydia Maria Child. Ticknor and Fields, 1865. pp. 155. HeinOnline, https://heinonline.org.

--- and Joan R Sherman. The Black Bard of North Carolina: George Moses Horton and His Poetry. University of North Carolina Press, 1997.

--- and Joan R Sherman. Naked Genius. The Black Bard of North Carolina: George Moses Horton and His Poetry. University of North Carolina Press, 1997.

---. “On the Poetic Muse.” Freedom's Journal. Ed. John B. Russwurm and Samuel E. Cornish. Freedom's Journal. New York. 08 Aug. 1828. Accessible Archives, http://www .accessible.com. 
--- "Reflections." Anti-Slavery Bugle. Eds. Marius R Robinson, Benjamin S. Jones, J. Elizabeth Hitchcock, Benjamin S. Jones, J. Elizabeth Jones, Oliver Johnson, Benjamin S. Jones. vol. 13, no 34. 17 Apr. 1858. Ohio American Antislavery Society. New-Lisbon https://chroniclingamerica.loc.gov/lccn/sn83035487/1858-04-17/ed-1/seq-4/

---. "The Slave Poet: The Slave's Complaint." The Child's Friend and Family Magazine (18431858). Boston, Vol. 4, no. 6, 1 Sept. 1845. pp. 255-257, ProQuest, https://www.proquest.com/.

--. "Spring." The Freedmen's Book. Ed. Lydia Maria Child. Ticknor and Fields, 1865. pp. 205. HeinOnline, https://heinonline.org.

Howells, William D. “Life and Letters." Harper's Weekly. New York: Harper's Magazine HathiTrust. https://hdl.handle.net/2027/mdp.39015023106241

Jaycox, Faith. Ebony Angels: A Collection of African-American Poetry and Prose, Three Rivers Press, 1996.

Jefferson, Thomas, and Frank Shuffelton. Notes on the State of Virginia. Penguin Books, 1999.

Johnson, Fenton. “Singing Hallelujia.” Ebony Angels: A Collection of AfricanAmerican Poetry and Prose. Ed. Faith Jaycox. Three Rivers Press, 1996.

The Juvenile Magazine, or Miscellaneous Repository of Useful Information. Philadelphia. 18021803. Hathitrust, https://babel.hathitrust.org/cgi/pt?id=hvd.hn2m7p\&view=1up\&seq=4 Juvenile Portfolio and Literary Miscellany: Devoted to the Instruction and Amusement of Youth. Philadelphia, 1812. WorldCat, https://www.worldcat.org/.

Kelly, R. Gordon. Children's Periodicals of the United States. Greenwood Press, 1984

Kilcup, Karen L. and Angela Sorby. Over the River and through the Wood: An Anthology of Nineteenth-Century American Children's Poetry. Johns Hopkins University Press, 2014 
Kilcup, Karen. "Re: Research Inquiry about Over the River and Through the Wood (2013)." Received by Tabitha Lowery, 13 Jan. 2020.

“Korey Wise.” Innocence Project, www.innocenceproject.org/cases/korey-wise/.

Kribbs, Jayne K. Annotated bibliography of American literary periodicals, 1741-1850. Ed. Everett Emerson. 1977, Print.

Levitt, Kendricks. Afro-American Voices, 1770s-1970s. Oxford Book. New York, 1970. Licato, Amanda Mehsima. “Paul Laurence Dunbar's Metapoetics.” J19: The Journal of Nineteenth-Century Americanists. vol. 7 no.1, 2019. pp.131-153. Project Muse, doi:10.1353/jnc.2019.0005.

Linton, William James. Poetry of America: Selections from One Hundred American Poets from 1776 to 1876 . London, 1878. Archive.org. https://archive.org/details/poetryamericase00lintgoog/page/n13/mode/2up

Locke, Alain. The New Negro: An Interpretation. New York. Arno Press, 1968.

Lowell, Amy. Tendencies in Modern American Poetry. Octagon Books, 1971.

Lynes, Katherine R. “'A Responsibility to Something Besides People:' African American Reclamation Ecopoetics.” African American Review, vol. 48 no.1, 2015, pp. 49-66. Project Muse, 10.1353/afa.2015.0012

Mackey, James. “Morning: A Prayer.” Ebony Angels: A Collection of AfricanAmerican Poetry and Prose. Ed. Faith Jaycox. Three Rivers Press, 1996.

Mallory, Devona. "I Remember Mama: Honoring the Goddess-Mother While Denouncing the Slaveowner-God in Phillis Wheatley's Poetry." New Essays on Phillis Wheatley. Eds. John Shields and Eric D Lamore. University of Tennessee Press, 2011. 
Martin, Jay. A Singer in the Dawn: Reinterpretations of Paul Laurence Dunbar. Internet Archive, New York: Dodd, Mead, 1975, archive.org/details/singerindawnre00cent.

McKissack, Patricia C. Paul Laurence Dunbar: A Poet to Remember. Chicago: Children's Press, 1984.

Mitchell, Koritha. "Debut of From Slave Cabins to the White House." Facebook. 3 Apr. 2020, 7:03 a.m., https://www.facebook.com/koritha.mitchell/posts/10222928026849094. accessed 3 Apr. 2020.

M. K. J. "Young People's Department." Home Mission Monthly. Vol. 12, Issue 6. Apr. 1898. Nineteenth Century Collections Online. Accessed 3 Nov. 2019. https://www.gale.com/.

Monaghan, E. Jennifer. Learning to Read and Write in Colonial America. University of Massachusetts Press, 2007.

Moody, Christina. "The Little Seed." Over the River and through the Woods: An Anthology of Nineteenth-Century American Children's Poetry. Eds. Karen Kilcup and Angela Sorby. Johns Hopkins University Press, 2014.

Moton, Robert R. "Introduction.” The Upward Path: A Reader for Colored Children. Eds Myron Pritchard and Mary White Ovington. New York, 1920. Archive.org. https://archive.org/details/upwardpathreader00pritrich/page/n6/mode/2up

Mott, Frank Luther. A History of American Magazines, 1741-1930, Vol. 3. Ebook, Cambridge, Mass .: Belknap Press of Harvard University Press, 1958, https://www .ebsco.com/.

Murdy, Anne-Elizabeth. Teach the Nation: Pedagogies of Racial Uplift in U.S. Women's Writing of the 1890s. Routledge, New York. 2003. 
Nash, Gary B. Forging Freedom: The Formation of Philadelphia's Black Community, 17201840. Harvard University Press, 1988.

National Intelligencer. vol. 11, no. 1580 - v. 13, no. 1916. Joseph Gales, 1810-1812.

Nelson-Dunbar, Alice Moore. The Dunbar Speaker and Entertainer: Containing the Best Prose and Poetic Selections by and About the Negro Race: With Programs Arranged for Special Entertainments. Illinois: J.L. Nichols and Co., 1920. Hathitrust. https://catalog.hathitrust.org/Record/100797606/Cite

---. "Paul Laurence Dunbar: Poet Laureate of the Negro Race.” Reprint from A.M.E. Church Review. Philadelphia: Reverdy C. Ransom, n.d. https://www .daytonhistorybooks.com/page/page/1565046.htm.

Nurhussein, Nadia. Rhetorics of Literacy: The Cultivation of American Dialect Poetry. Ohio State University Press, 2013.

Nye. Russel B. "Marius Robinson, A Forgotten Abolitionist Leader.” Ohio History Connection. https://resources.ohiohistory.org/ohj/browse/displaypages.php?display $\% 5 b \% 5 \mathrm{~d}=0055 \& \mathrm{di}$ splay $\% 5 \mathrm{~b} \% 5 \mathrm{~d}=138 \&$ display $\% 5 \mathrm{~b} \% 5 \mathrm{~d}=154$.

O'Neale, Sondra. "Roots of Our Literary Culture: George Moses Horton and Biblical Protest." Obsidian (1975-1982), vol. 7, no. 2-3, 1981, pp. 18-28.

Ohio History Connection. “About Anti-slavery Bugle.” Chronicling America: Historic American Newspapers. n.d. https://chroniclingamerica.loc.gov/lccn/sn83035487/.

Open Library. "Young People's Missionary Movement of the United States and Canada." Openlibrary.org. Date Accessed 29 Dec. 2019. https://openlibrary.org/publishers/Young_People's_Missionary_Movement_of_the_Unite d_States_and_Canada. 
Our Young Folks: An Illustrated Magazine for Boys and Girls. Boston: Ticknor and Fields.

1865-1873. HathiTrust. https://catalog.hathitrust.org/Record/000062183/Home.

Partin, Elliot. “Freedom's Journal (1827-2829).” BlackPast.org.

www.blackpast.org/african-american-history/freedom-s-journal-1827-1829/.

“Paul Laurence Dunbar Collection” OhioLink Finding Aid Repository. Ohio.gov. http://ead.ohiolink.edu/xtfead/view?docId=ead/ODa0004.xml;chunk.id=c02_1CC;brand=default.

Payne, Daniel A. "Fragments of Thought-No.2" Anglo-African Magazine.

Vol. 1 issue 4, Apr 1859. 119-121, https://www.ebsco.com/.

Podell, Leslie. The Sojourner Truth Project. n.p. n.d.

Poe, Edgar Allan. The Poetic Principle. Home Journal. 1850, vol. 36, no 238. pp.1-6. 31 Aug. 1850. Edgar Allan Poe Society. https://www .eapoe.org/works/essays/poetprnb.htm.

Polgar, Paul J.““To Raise Them to an Equal Participation’: Early National Abolitionism, Gradual Emancipation, and the Promise of African American Citizenship." Journal of the Early Republic, vol. 31, no. 2, 2011, pp. 229-258. JSTOR, www.jstor.org/stable/41261611.

Poling, Toni. Personal Interview, February 2019.

Popova, Maria. “A Brief History of Children's Picture Books and the Art of Visual Storytelling." The Atlantic. https://www.theatlantic.com/entertainment/archive/2012/02/a-brief-historyof-childrens-picture-books-and-the-art-of-visual-storytelling/253570/.

Prelutsky, Jack, and Arnold Lobel. The Random House Book of Poetry for Children. Random House, 1983. 
Presbyterian Historical Society. "Biographical Note/Administrative History.” PHS.

https://www.history.pcusa.org/collections/research-tools/guides-archival-collections/nccrg-20.

Pritchard, Myron and Mary White Ovington. The Upward Path: A Reader for Colored Children. New York, 1920. Archive.org. https://archive.org/details/upwardpathreader00pritrich/page/n6/mode/2up.

Pybus, Cassandra. Epic Journeys of Freedom: Runaway Slaves of the American Revolution and Their Global Quest for Liberty. Boston: Beacon Books, 2006.

Redding, J. Saunders. "Portrait against Background." A Singer in the Dawn: Reinterpretations of Paul Laurence Dunbar. Ed. Jay Martin. New York: Dodd, Mead, pp. 39-44 1975.

Ripley, C. Peter; et al., Editors. Black Abolitionist Papers. Chapel Hill, University of North Carolina Press. Print. HeinOnline, https://heinonline.org.

Robinson, Marius R. Anti-slavery Bugle. eds. Benjamin S. Jones, J. Elizabeth Hitchcock, Benjamin S. Jones, J. Elizabeth Jones, Oliver Johnson, Benjamin S. Jones. vol. 1 no.1vol. 16, no 38. Ohio American Antislavery Society, 1851-1859. New-Lisbon, https://chroniclingamerica.loc.gov/lccn/sn83035487/.

Rochelle, Belinda. Words with Wings: A Treasury of African-American Poetry and Art. Singapore: HarpersChildren, 2001. Amazon. https://www .amazon.com/Words-WingsTreasury-African-American-Poetry/dp/0688164153.

Rollins, Charlemae Hill. Black Troubadour: Langston Hughes. Rand McNally, 1970. 
---. Christmas gif': An Anthology of Christmas Poems, Songs, and Stories.

New York: Morrow Junior Books, 1993. Archive.org. https://archive.org/details/christmasgifanth00roll/page/n23.

Romans, Bernard, and Kathryn E. Holland Braund. A Concise Natural History of East and West Florida. University of Alabama Press, 2011.

Rusert, Britt. Fugitive Science: Empiricism and Freedom in Early African American Culture. New York University Press, 2018.

---. "The Science of Freedom: Counterarchives of Racial Science on the Antebellum Stage.” African American Review, vol. 45, no. 3, 2012, pp. 291-308.

Russwurm, John. B. and Samuel E. Cornish. Freedom's Journal. March 1827-1829. New York. Accessible Archives. https://www.accessible-archives.com/collections/african-americannewspapers/freedoms-journal/.

Sapirstein, Ray Julius. Out from Behind the Mask; The Illustrated Poetry of Paul Laurence Dunbar and Photograph at Hampton Institute. 2005. UT Austin, PhD dissertation.

Schweiger, Beth Barton. "A Social History of English Grammar in the Early United States." Journal of the Early Republic, vol. 30, no. 4, 2010, pp. 533-555. JSTOR, www.jstor.org/stable/40926064.

Schweinitz Rebecca De. If We could Change the World: Young People and America's Long Struggle for Racial Equality. North Carolina Press, 2009.

Scott-Childress, Reynolds J. "Paul Laurence Dunbar and the Project of Cultural Reconstruction." African American Review, vol. 41, no. 2, 2007, p. 367. Gale Literature Resource Center, https://www.gale.com/c/literature-resource-center. 
Sherman, Joan R. African-American Poetry of the Nineteenth Century: An Anthology. University of Illinois Press, 1992.

---. Invisible Poets: Afro-Americans of the Nineteenth Century. University of Illinois Press, 1974.

Shields, John C. The American Aeneas: Classical Origins of the American Self. 1st ed., University of Tennessee Press, 2001.

Shields, John C. "Phillis Wheatley's Subversion of Classical Stylistics.” Style, vol. 27, no. 2, 1993, pp. 252-270. JSTOR, www.jstor.org/stable/42946040.

---. Phillis Wheatley's Poetics of Liberation: Backgrounds and Contexts. 1st ed., University of Tennessee Press, 2008.

Shields, John C, and Eric D Lamore. New Essays on Phillis Wheatley. University of Tennessee Press, 2011.

Smith, Katherine Capshaw. "The Legacy of the South: Revisiting the Plantation Tradition." Children's Literature of the Harlem Renaissance. Indiana University Pres, 2004.

Smith, Katharine Capshaw and Anna Mae Duane. Who Writes for Black Children?: African American Children's Literature before 1900. University of Minnesota Press, 2017.

Sorby, Angela. “Conjuring Readers: Antebellum African American Children's Poetry.” Who Writes for Black Children?: African American Children's Literature before 1900. University of Minnesota Press, 2017.

---. Schoolroom Poets: Childhood and the Place of American Poetry, 1865-1917. University of New Hampshire Press, 2005. 
---. "Women Poets, Child Readers." Eds. Jennifer Putzi, and Alexandra Socarides. A History of Nineteenth-Century American Women's Poetry. Cambridge University Press, 2017.

Spires, Derrick Ramon. The Practice of Citizenship: Black Politics and Print Culture in the Early United States. University of Pennsylvania Press, 2019.

Stewart, Carole. Temperance and Cosmopolitanism: African American Reformers in the Atlantic World. Penn State Press, 2018.

Stewart, Jeffrey C. The New Negro: The Life of Alain Locke. Oxford University Press, 2018.

Still, William, 1821-1902. The Underground Railroad: A Record of Facts, Authentic Narratives, Letters, \&c., Narrating the Hardships, Hair-breadth Escapes, And Death Struggles of the Slaves In Their Efforts for Freedom, As Related by Themselves And Others, Or Witnessed by the Author; Together With Sketches of Some of the Largest Stockholders, And Most Liberal Aiders And Advisers, of the Road. Philadelphia: Porter \& Coates, 1872. HathiTrust. https://babel.hathitrust.org/cgi/pt?id=uiuo.ark:/13960/t2c826689\&view=1up\&seq=9.

Swedenborg, Emanuel. Heaven and Hell: Also the World of Spirits or Intermediate State, from Things Heard and Seen. New-Church Union, Boston. 1889.

Sweet, Timothy. Literary Cultures of the Civil War. University of Georgia Press, 2016.

Tate, Don. Poet: The Remarkable Story of George Moses Horton of Chapel Hill. Peachtree, 2015. 
Thompson, David D. “The Family.” Northwestern Christian Advocate. Vol. 55. July 31, 1907. Google Books. https://books.google.com/books?id=KG0xAQAAMAAJ\&pg=PP2\#v=onepage\&q\&f=fals e.

Twain, Mark. "Explanatory." Adventures of Huckleberry Finn. New York: Charles L Webster and Company, 1885. Gutenberg.org. https://www.gutenberg.org/files/76/76-h/76-h.htm

---. “Two Little Tales.” St. Nicholas. Ed. Mary Mapes Dodge. Vol. 29. 1901. Google Books. https://books.google.com/books?id=pmoyAQAAMAAJ\&lpg=PA1190\&ots=uB4VUPGb pI\&dq=St.\%20Nicholas\%20paul\%20laurence\%20dunbAr\&pg=PA1190\#v=onepage\&q= paul\%20laurence\%20dunbAr\&f=false.

Walser, Richard. Black Poet. New York, 1966.

Warren, Kenneth W. What Was African American Literature? Harvard University Press, 2011.

Weikle-Mills, Courtney. "Free the Children: Jupiter Hammon and the Origin of African American Children's Literature." Who Writes for Black Children?: African American Children's Literature before 1900. Eds. Katharine Capshaw and Anna Mae Duane. University of Minnesota Press, 2017.

Welter, Barbara. "The Cult of True Womanhood: 1820-1869.” American Quarterly, vol. 18, no.2, 1966. Ebscohost. https://www .ebsco.com/

Wheatley, Phillis. The Collected Works of Phillis Wheatley. Edited by John C Shields, Oxford University Press, 1988. 
--- "Goliath of Gath.” The Juvenile Magazine (1811-1813), no. 4, Aug. 01, 1813, pp. 50. Proquest, https://www.proquest.com/.

---. "An Hymn to the Evening." Readings from Negro Authors for Schools and Colleges. Eds Otelia Cromwell, Lorenzo Turner, and Eva Dykes. New York: Harcourt, Brace. 1931. Print.

---. “Hymn to Humanity.” Freedom's Journal. Eds. John. B. Russwurm and Samuel E. Cornish. 9 Nov. 1827. Accessible Archives. http://www.accessible.com.

---. "Hymn to the Morning." Freedom's Journal. Eds. John. B. Russwurm and Samuel E. Cornish. 9 Nov. 1827. Accessible Archives. https://www.accessible-archives.com/.

---. "Liberty and Peace.” Early Negro American Writers: Selections With Biographical And Critical Introductions. Ed. Benjamin Griffith Brawley. Freeport, N.Y.: Books for Libraries Press, 1968.

---. "Niobe in Distress for her Children Slain by Apollo" Early Negro American Writers: Selections With Biographical And Critical Introductions. Ed. Benjamin Griffith Brawley. Freeport, N.Y.: Books for Libraries Press, 1968.

---. "On the Death of J.C. an Infant." "Original Communications for the Freedom's Journal." Freedom's Journal. Eds. John. B. Russwurm and Samuel E. Cornish. Accessible Archives. 23 Mar. 1827. https://www.accessible-archives.com/.

--- "On the Death of a Young Lady." The Black Man: His Antecedents, His Genius, and His Achievements. Ed. William Wells Brown. Documenting the American South. New York: Thomas Hamilton, 1863. https://docsouth.unc.edu/neh/brownww/menu.html --- "On the Death of J.C. an Infant, An Hymn to the Morning." The Juvenile Magazine (18111813), no. 4, Aug. 01, 1813, pp19. Proquest, https://www.proquest.com/. 
--- "On the Death of Rev. Mr. George Whitefield." Early Negro American Writers: Selections With Biographical And Critical Introductions. Ed. Benjamin Griffith Brawley. Freeport, N.Y.: Books for Libraries Press, 1968.

---. "On Imagination.” Early Negro American Writers: Selections With Biographical And Critical Introductions. Ed. Benjamin Griffith Brawley. Freeport, N.Y.: Books for Libraries Press, 1968.

---. Poems on Various Subjects, Religious and Moral. By Phillis Wheatley, Negro Servant to Mr. John Wheatley, of Boston, in New England, London, MDCCLXXIII [1773]. Eighteenth Century Collections Online, https://www.gale.com/.

--- "Thoughts on the Work of Providence.” The Freedmen's Book. Ed. Lydia Maria Child. Ticknor and Fields. HeinOnline, 1865. https://heinonline.org/HOL/P?h=hein.slavery/fredbk0001\&i=102\&a=d3Z1LmVkdQ.

---. "To His Excellency General Washington.” Early Negro American Writers: Selections With Biographical And Critical Introductions. Ed. Benjamin Griffith Brawley. Freeport, N.Y.: Books for Libraries Press, 1968.

--- “To the Right Honorable William, Earl of Dartmouth.” The Juvenile Magazine (18111813), no. 4, Aug. 01, 1813, pp.19. Proquest, https://www.proquest.com/

---. “To the University of Cambridge.” Early Negro American Writers: Selections With Biographical And Critical Introductions. Ed. Benjamin Griffith Brawley. Freeport, N.Y.: Books for Libraries Press, 1968.

White, Newman Ivey, and Walter Clinton Jackson, editors. An Anthology of Verse by American Negroes. Trinity College Press, 1924. 
Williams, Justin. “The Verses from our Pen to Him Belong”: National Identity in the Political Homages of George Moses Horton” North Carolina Literary Review Vol. 28 no. 144. The University of North Carolina Press, 2019.

Wirzbicki, Peter. "Black Transcendentalism: William Cooper Nell, the Adelphic Union, and the Black Abolitionist Intellectual Tradition." Journal of the Civil War Era, vol. 8, no.2, 2018, pp. 269-290.

W.J. Linton, ed. Poetry of America: Selections from One Hundred American Poets from 1776 to 1876. London, 1878. Print.

Wolfinger, James. “African American Migration.” Encyclopedia of Greater Philadelphia, philadelphiaencyclopedia.org/archive/african-american-migration/.

Woolman, John. Journal of John Woolman. Boston, James R. Osgood and Co. 1871. HeinOnline, https://heinonline.org.

Wright State University Special Collections and Archives. "Selected Resources.” Wright State University, 2019. https://www.libraries.wright.edu/special/dunbar/resources.

Young, Jennifer R. Marketing a Sable Muse: The Cultural Circulation of Phillis Wheatley, 1767-1865, Howard University, Ann Arbor, 2004. ProQuest Dissertations Publishing, https://www.proquest.com/.

Youth's Companion. "Stories for the Family.” Ed. Nathaniel Willis and Daniel Sharp Ford. Vol. 74, Oct. 1906. https://books.google.com/books?id=nttCAQAAMAAJ\&lpg=PA501\&dq=youth\%E2\%80 $\% 99 \mathrm{~s} \% 20$ companion $\% 20$ paul\%20laurence $\% 20 \mathrm{dunbar} \& \mathrm{pg}=\mathrm{PA} 502 \# \mathrm{v}=$ onepage $\& \mathrm{q}=\mathrm{dunb}$ $\operatorname{ar} \& f=$ false 